\title{
Economics of Weather Index-Based Insurance: Analysis of Smallholder Farmers' Preferences and the Impact of Insurance on Productivity in Kenya
}

\author{
Dissertation \\ to obtain the Ph. D. degree \\ in the International Ph. D. Program for Agricultural Sciences in Goettingen (IPAG) \\ at the Faculty of Agricultural Sciences, \\ Georg-August-University Goettingen, Germany
}

Presented by:

Kenneth Waluse Sibiko

Born in: Kakamega, Kenya

Goettingen, September 2016 
D7

1. Name of supervisor: Prof. Dr Matin Qaim

2. Name of co-supervisor: Prof. Dr Xiaohua Yu

Date of dissertation: $17^{\text {th }}$ November 2016 


\section{Summary}

Climatic risks are a major challenge for rural communities, especially those whose livelihoods directly depend on agriculture. Weather extremes affect crop productivity not only through the direct relationship between weather variables and yields, but also through the negative effects of such shocks on farmers’ investment behavior. In particular, smallholder farmers are vulnerable partly because they are predominantly located in the tropics where exposure to climate variability is high, but also because they lack the resources and the capacity to properly cope with risks. Agricultural insurance is one possible solution, but for long formal crop insurance remained unavailable in most developing countries. Institutional constraints, including high transaction costs, the spatially correlated nature of agricultural risks, and classical issues of information asymmetry, discouraged insurers from offering agricultural insurance contracts.

Recently there have been efforts to change this situation through the development and provision of weather index insurance (WII) contracts. A WII contract is advantageous because the insurer relies on an objectively measured weather variable that is correlated with farm losses but which cannot be manipulated through farmers' actions. Usually indexes used in WII are measured at the aggregate level, minimizing issues of moral hazard and adverse selection into insurance programs. Moreover, the insurer is saved from having to assess losses on each insured farm, an aspect that cuts down administrative costs. In turn, if the WII contracts are well designed, insured farmers can benefit because of relatively affordable insurance premiums and faster claim payments in case of a devastating weather event.

Despite these potential benefits, demand for the piloted WII products has generally been low. Farmers’ preferences have rarely been analyzed; hence it may be that existing WII contracts are not sufficiently tailored to the needs of smallholder producers. Understanding the main obstacles from the farmers' perspective can help in improving the design and implementation of WII schemes. Furthermore, WII initiatives are usually intended to contribute towards poverty reduction in the long run. However, very little empirical evidence is available in the literature on the economic and social impacts of existing WII 
programs. To address the mentioned knowledge gaps, in this study two research objectives are pursued, each one representing one of the main chapters of this dissertation.

The first objective relates to farmers’ preferences for WII. We combine data from a survey and a discrete choice experiment (DCE) conducted in Kenya to analyze farmers' experience with an existing WII program and preferences towards specific improvements in WII contract design attributes. Specifically, the DCE included price and non-price attributes related to proximity to weather stations, rainfall thresholds, insurer transparency, and group rather than individual contracts. Kenya is an interesting setting for the study because farmers there already had some experience with WII. In particular the so-called Kilimo Salama program has been in existence since 2009, providing index-based crop insurance products in different parts of the country. For the analysis we use a mixed logit model that accounts for preference heterogeneity given that farmers may not always portray similar preferences.

Results indicate that the existing WII contracts are probably too expensive from farmers' point of view. This could be one reason why insurance demand remains low. Besides affordability, many smallholder farmers do not fully understand how the insurance functions. Transparent provision of information on realized rainfall measurements and threshold levels would improve farmers' willingness to pay for insurance. Mechanisms that improve the effectiveness of WII contracts, such as increasing the number of weather stations, are also valued by farmers, but not to the same extent as frequent communication. In addition, offering WII contracts to groups - rather than individual farmers - could be a promising avenue for achieving more widespread uptake of WII among smallholder farmers. Group contracts could reduce transaction costs. They could also offer important platforms through which farmers can learn and better understand the complexities of index insurance contracts.

The second research objective pursued in this dissertation relates to the effects of WII adoption on input use and crop productivity. Weather risk has been shown to affect the usage of productive inputs including fertilizers and modern seed technologies. Risk-averse farmers are usually reluctant to use external inputs, when rainfall and temperature uncertainties are too high. However, because of this tendency of avoiding risks, they also forego potential yield gains that they could realize if they utilized 
more external inputs. Using randomized field experiments, a few recent studies have analyzed whether the provision of WII can improve investments in riskier but more productive technologies. Unlike these previous studies, we use observational data from a survey of smallholder farmers, analyzing the effects of actual participation in the Kilimo Salama WII Program in Kenya. For the analysis we utilize a treatment regression model with instrumental variables. Empirical results reveal a significant increase in the use of fertilizer and improved seeds as a result of adopting WII. Further analysis also indicates a significant improvement in maize productivity, which mainly comes from the increase in fertilizer application. The results emphasize that WII is indeed one mechanism for promoting productivity growth, however, this potential is not yet fully realized, because only a small proportion of farmers has so far participated in the WII Program.

Overall, the study concludes by stressing the need to educate farmers about novel index insurance products that they may not be familiar with. Although some training is currently being provided as part of Kilimo Salama, this has to be intensified to inform farmers on potential benefits and limitations of the WII products. For this it may be useful to harmonize insurance trainings with public agricultural extension, so as to improve the effectiveness of the training interventions. Strengthening producer groups and encouraging farmer-to-farmer knowledge exchange within group networks are also other ways to improve the rate of insurance uptake. WII is definitely not a silver bullet for productivity growth in the small farm sector; however, providing effective WII contracts jointly with other support services may contribute positively to the well-being of risk-prone farming communities. 


\section{Acknowledgements}

I would like to thank my main supervisor Prof. Qaim for his always prompt feedback and for his guidance and support at every stage of writing this dissertation. I really cannot find the words to express my gratitude. To the other members of my examination panel, Prof. Yu and Prof. Musshoff, thank you for accepting to be part of the committee. I further thank Prof. Musshoff and Dr. Feil who reviewed an earlier version of my research proposal and discussion paper that have contributed to this dissertation. My sincere gratitude also goes to Dr. Veettil who assisted me in designing the choice experiment and for his valuable suggestions in the write-up of Chapter 2.

Funding for the research was provided by the Kenyan National Commission for Science, Technology, and Innovation (NACOSTI) and the German Research Foundation (DFG). Additional financial support from the German Academic Exchange Service (DAAD) is also gratefully acknowledged. The data collection would have been impossible were it not for the assistance of Kilimo Salama personnel and Ministry of Agriculture extension officers in Embu, Kenya. I sincerely appreciate the team of enumerators, and sampled farmers for their patience in responding to questions and participating in a tedious choice experiment.

I am also indebted to Ilona Hoepfner, my office mates Michael Euler and Zewdu Abro, to Elijah Muange, Kibrom Sibhatu, Stefan Koppmair, Priscilla Wainaina, Dennis Ochieng, Sylvester Ogutu, and other former and current chair colleagues for their invaluable advice and for providing moral support. To my parents and family, thank you for the inspiration and continuous encouragement during the time of writing this dissertation. Last, but most important, thanks to the Almighty God for good health and for his mercies all through my doctoral research. 


\section{Table of Contents}

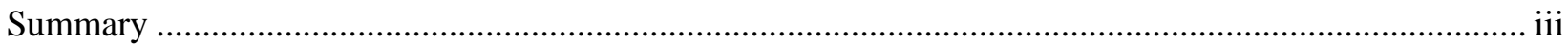

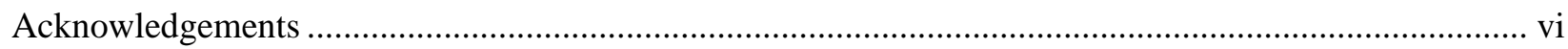

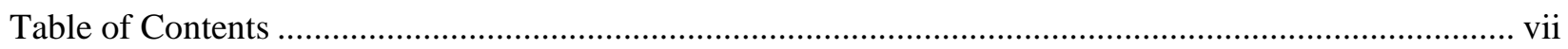

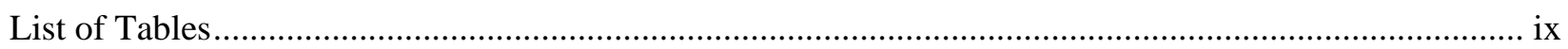

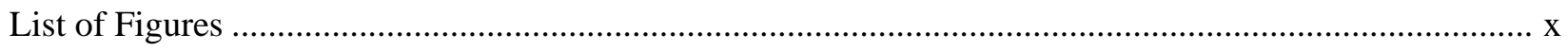

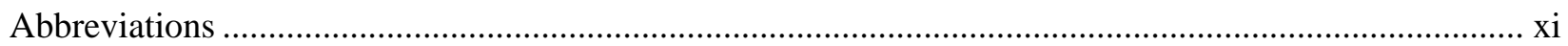

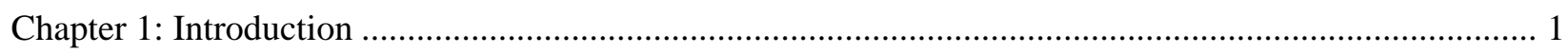

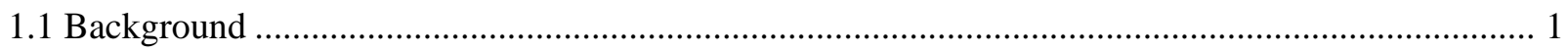

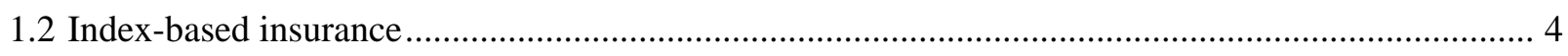

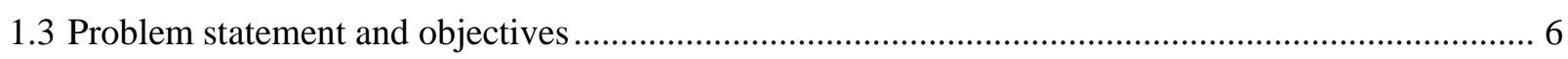

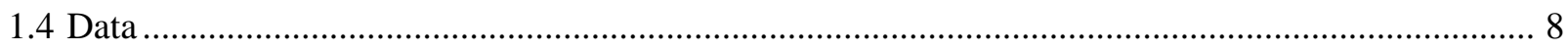

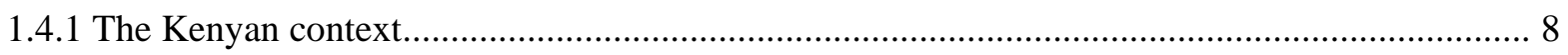

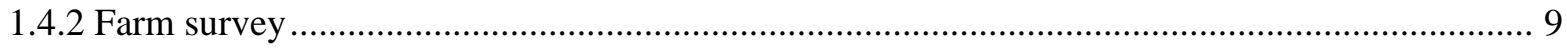

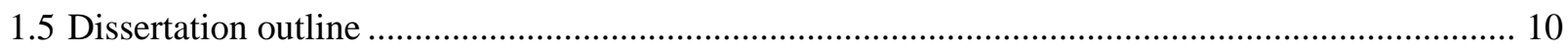

Chapter 2: Small Farmers’ Preferences for Weather Index Insurance: Insights from Kenya .................... 11

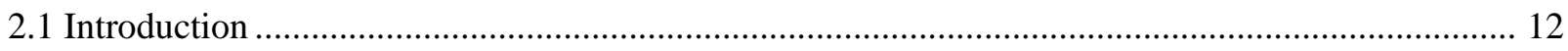

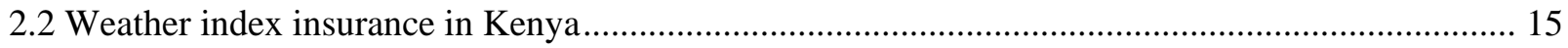

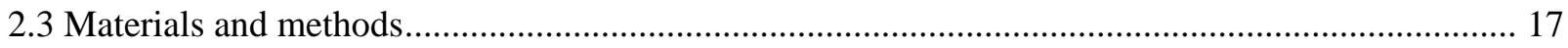

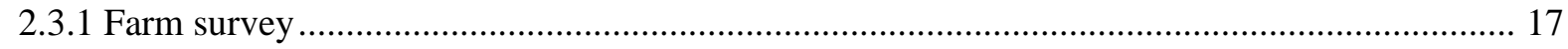

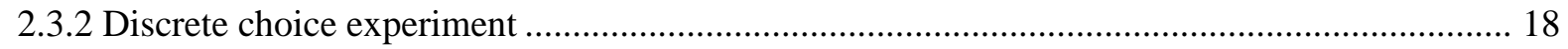

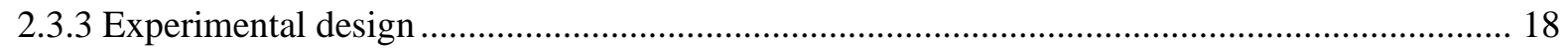

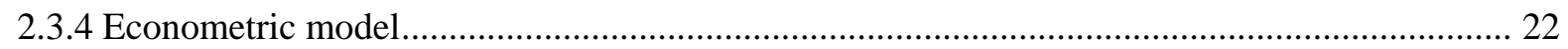

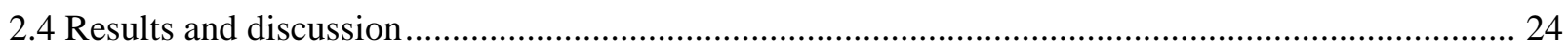

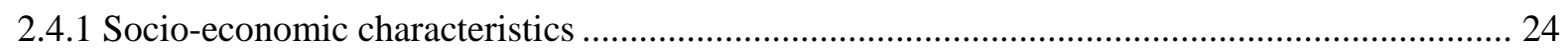




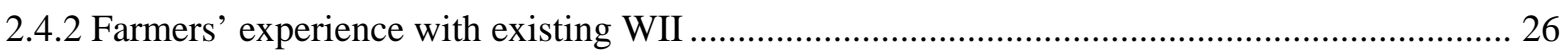

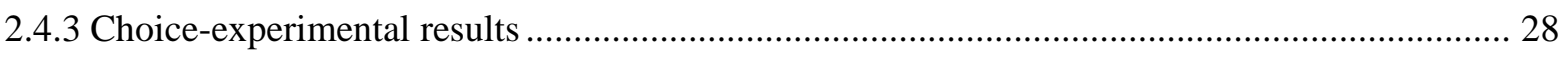

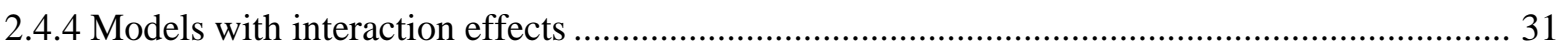

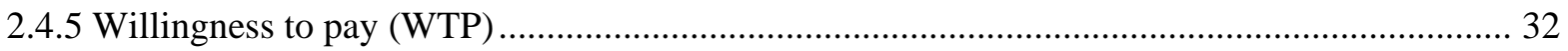

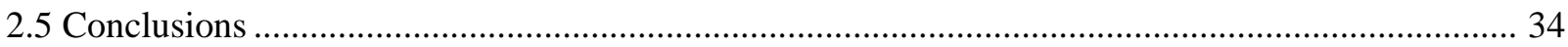

Chapter 3: Effects of Weather Index Insurance on Input Use and Productivity in Kenya ......................... 36

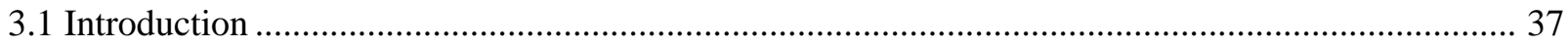

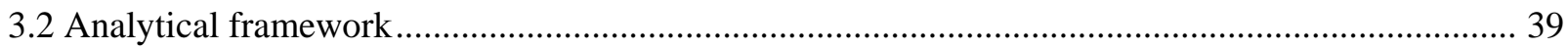

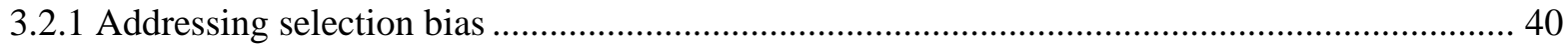

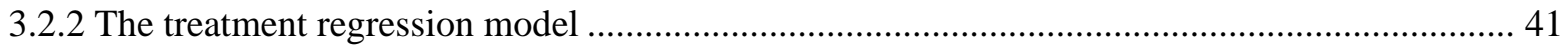

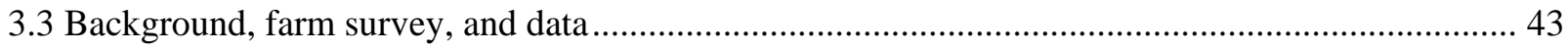

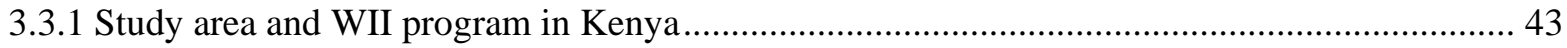

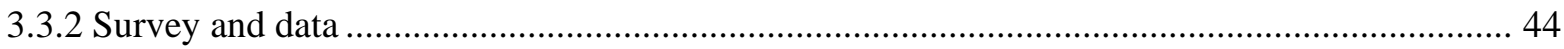

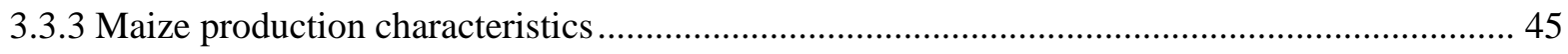

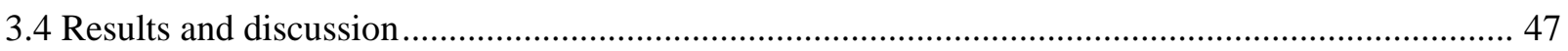

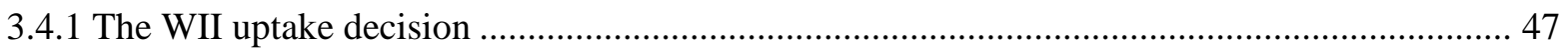

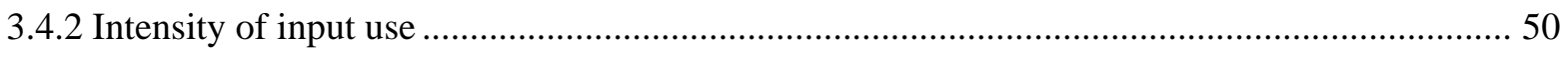

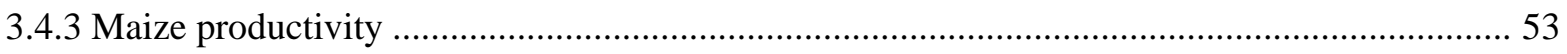

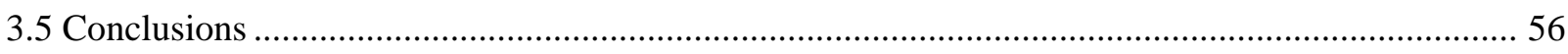

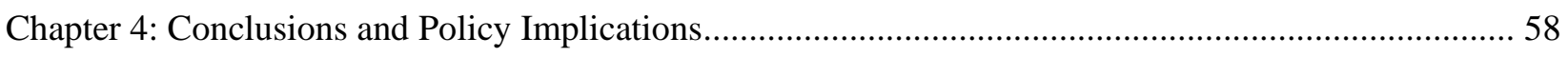

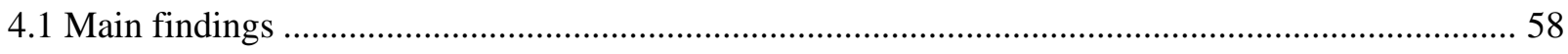

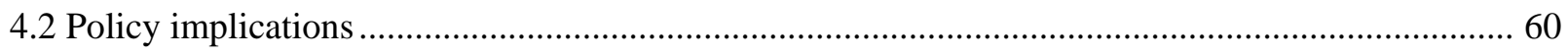

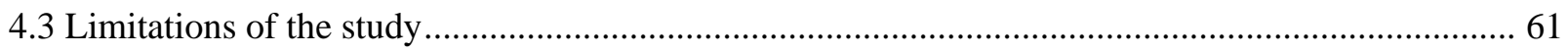

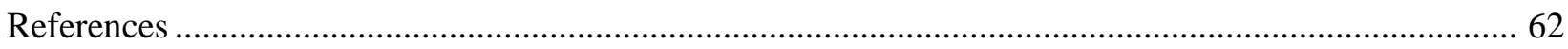

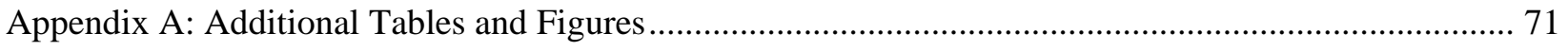

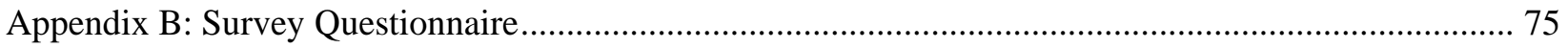

viii 


\section{List of Tables}

Table 2.1: Attributes of WII contracts used in the choice experiment .................................................. 19

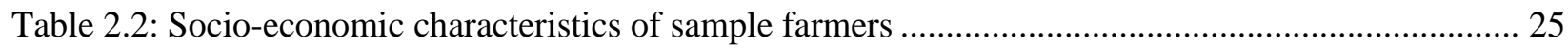

Table 2.3: Farmers' experience with agricultural shocks during the past five years................................ 26

Table 2.4: Number of farmers who purchased WII and received payment (2009-2014)......................... 26

Table 2.5: Estimated model results for weather index insurance preferences......................................... 30

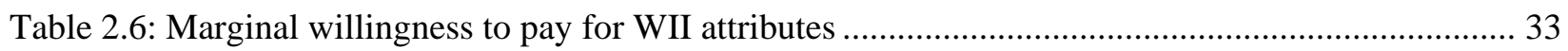

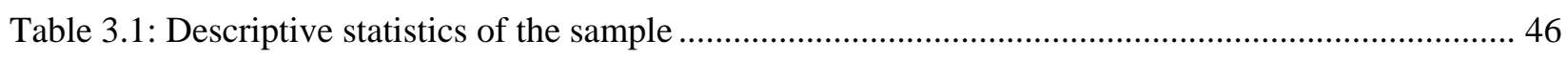

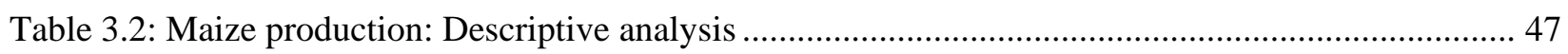

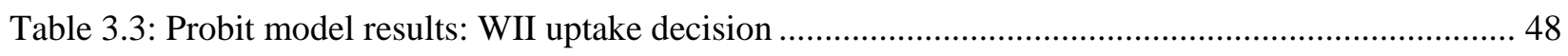

Table 3.4: Treatment-effect regression estimates: Intensity of inorganic fertilizer and maize seed ........... 51

Table 3.5: Treatment-effect regression estimates: WII effect on maize yields (log, kg/acre)..................... 55

Table A 1: Correlation between instrument and production variables with full sample........................... 71

Table A 2: Correlation between instrument and production variables: Non-insured farmers only............. 71

Table A 3: WII uptake equation (First stage) estimates for maize yield regressions ............................... 73

Table A 4: Treatment-effect regression estimates: Intensity of use for animal manure............................. 74 


\section{List of Figures}

Figure 1.1: Rainfall measurement and pay-out for a weather index insurance contract ............................ 5

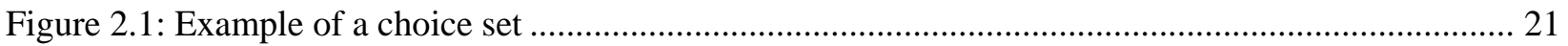

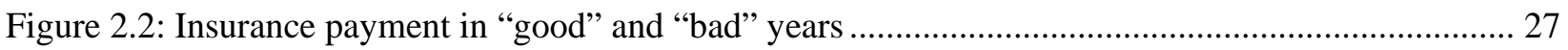

Figure 2.3: Farmers’ overall satisfaction with the existing WII program ................................................ 28

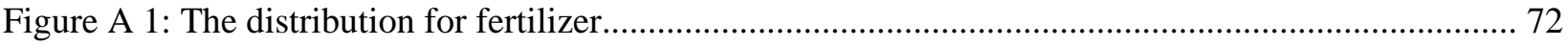

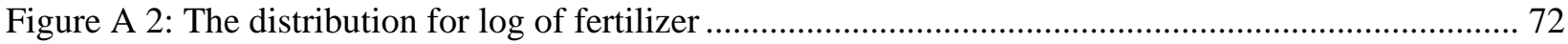

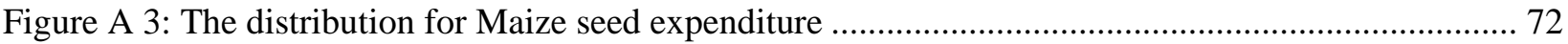

Figure A 4: The distribution for log of Maize seed expenditure .............................................................. 72 


\begin{tabular}{ll}
\hline & \\
\hline FAO & Food and Agricultural Organization \\
SSA & Sub-Saharan Africa \\
DFID & Department for International Development, UK \\
IPCC & Intergovernmental Panel on Climate Change \\
WII & Weather Index-based Insurance \\
ILRI & International Livestock Research Institute \\
FSD & Financial Sector Deepening, Kenya \\
IFAD & International Fund for Agricultural Development \\
IFC & International Finance Corporation \\
ACRE & Agriculture and Climate Risk Enterprise \\
DCE & Discrete Choice Experiment \\
ML & Mixed logit \\
IIA & Independence of Irrelevant Alternatives \\
ASC & Alternative Specific Constant \\
\hline & Willingness to Pay \\
\hline & Instrumental Variables \\
\hline &
\end{tabular}




\section{Chapter 1: Introduction}

\subsection{Background}

The first Millennium Development Goal was to halve the prevalence of extreme poverty and hunger in the world by the year 2015. On average for the developing countries as a whole, at least the poverty target has been achieved. Nevertheless, it is estimated that one billion people in the world are still extremely poor, living on less than $\$ 1.25$ per day (FAO, 2015). Similarly, about 795 million people suffer from severe undernourishment which is a worrying state of affairs (FAO et al., 2015). Sub-Saharan Africa (SSA) as a region has totally lagged behind the rest of the developing world: close to half of the world's poor live in SSA while at least 23\% of the region's population is considered undernourished (FAO, 2015; FAO et al., 2015). Furthermore, the majority of the poor are found in rural areas where they either directly or indirectly depend on agriculture for their livelihoods. Thus, economic growth in the agricultural sector is often more pro-poor than growth in other sectors of the economy (Thirtle et al., 2003; FAO, 2015).

Reduction in poverty has also historically been linked to growth in agricultural productivity (DFID, 2004). Countries that increased their agricultural productivity the most such as China, and much of South-East Asia and Latin America, have also been able to achieve the most rapid poverty reduction rates (Lipton, 2006). SSA countries on the other hand have registered stagnating or sometimes declining agricultural productivity during the last decades, which also correlates with increasing poverty and food insecurity in some countries in that region (DFID, 2004). Much of the growth in agricultural productivity elsewhere was realized through the "Green Revolution” which generally involved a shift towards intensive use of fertilizer and higher-yielding crop varieties. Unfortunately, SSA never experienced that wave of productivity growth (Evenson and Gollin, 2003). Hence, governments and development agencies are keen to understand how the Asian Green Revolution could be replicated in Africa. However, in comparison to the Asian model of the 1960 and 1970s, additional challenges are how to intensify more sustainably, while making agricultural systems more resilient to climate change (DFID, 2004; Denning et al., 2009; Pingali, 2012; Otsuka and Larson, 2013). 
Agricultural impacts associated with climate change and climate variability are immense. For example, the increase in temperatures and unpredictable seasonal rainfalls are already negatively affecting global cereal production, more so in the vulnerable regions of South Asia and Africa (Knox et al., 2012; Lesk et al., 2016). In addition, production uncertainties will increase with climate change. It is expected that average temperatures will be warmer and variability in precipitation and extreme events will become more frequent and severe in the future. These trends may have severe implications for food availability (IPCC, 2012; Wheeler and von Braun, 2013; Challinor et al., 2016). Uncertainties will also have indirect implications for agricultural productivity through behavioral response of producers. Because of the widely observed risk aversion among farmers, uncertainty tends to reduce agricultural investments, which in turn may lead to overall declines in yields (Cooper et al., 2008). As such, improving the effectiveness of climate risk management will be critical for future agricultural and rural development.

Smallholder farmers tend to use various strategies to cope with weather shocks. Some of them are undertaken pre-season to mitigate risks (e.g., choosing stress-tolerant varieties, intercropping, irrigation, farm and off-farm diversification, among others). During the season farmers also make risk-reducing adjustments in input allocation depending on the realized weather conditions. Still, other risk management strategies are undertaken ex-post, and they aim at minimizing the economic hardships after a devastating shock (e.g., selling assets, borrowing, informal insurance within social networks, or temporary off-farm work, among others) (Cooper et al., 2008; Shiferaw et al., 2014).

While these local strategies are generally effective for stabilizing income and smoothing consumption, they may also result in huge opportunity costs, for example, because of foregone productivity gains from specialization or adequate input use (Dercon and Christiaensen, 2011). Ex-post coping strategies also fail when it comes to covariate risks that affect many households within the same locality. During times of hardship, prices of most assets drop; wage rates also go down since many people try to find employment simultaneously (Hazell, 1992; Morduch, 1999). Moreover, as resource-poor households face continuous shocks and dispose of productive assets, their vulnerability to future risks increases. It may take many years for the affected households to recover. Thus, uninsured risk is capable 
of not only worsening the condition among those already poor, but also pulling those who were initially non-poor back into lasting poverty traps (Dercon, 2004; Carter and Barrett, 2006; Barnett et al., 2008; Dercon and Christiaensen, 2011).

Risk transfer options such as insurance can be used to cushion producers from weather shocks. The insurance providers often operate in different regions where they enlist clients with varying levels of risk exposure. Risk pooling arrangements can therefore be utilized to offer effective protection for weather risks. But agricultural insurance in its conventional form has been challenging for private insurers, because of classical information asymmetry problems of moral hazard and adverse selection. Moral hazard arises from the fact that farmers may alter their production actions to increase the possibility of compensation. To reduce this problem, the insured farmer might be required to retain a percentage of his risk through what is referred to as a "deductible”. But still, the process of monitoring individual farms is prohibitively expensive (Hölmstrom, 1979). In addition, with adverse selection the insurer is likely to make losses, since high risk and less productive farmers will be quick to take an insurance cover (Akerlof, 1970; Just et al., 1999).

Another problem is the covariate nature of risks in agriculture. Without external reinsurance possibilities, an insurance provider is likely to run bankrupt, when a severe weather event affects most of the clients simultaneously (Miranda and Glauber, 1997). Overall the conventional form of agricultural insurance involves too high transaction costs. The costs are particularly high in developing countries, because majority of the clients there are small farms in rural areas where infrastructure is less developed (Mahul and Stutley, 2010). In high-income countries, crop insurance schemes have been successful because of heavy government funding, either in the form of premium subsidies or contribution towards part of the administrative costs. However, in low-income countries, where government bail-out is fiscally limited, agricultural insurance has remained more or less non-existent (Hazell, 1992; Miranda and Farrin, 2012). 


\subsection{Index-based insurance}

Because of the problems with conventional crop insurance, various experts suggested index-based insurance contracts as possible alternatives (Halcrow, 1949; Miranda, 1991; Hazell, 1992). The basic idea behind index insurance is that instead of basing on actual yield losses; the insurer relies on a completely exogenous variable (or "index") that serves as a proxy for farm losses. An ideal index is one that is objectively measurable, verifiable, and highly correlated with farm losses (Barnett et al., 2008). Typical examples of indexes include average area yield or revenue, cumulative rainfall, mean temperature, humidity, and satellite-measured indexes (Miranda, 1991; Deng et al., 2007; Kellner and Musshoff, 2011; Chantarat et al., 2013). But generally in lower-income countries, index insurance products that rely on weather variables are the most widely piloted due to difficulties in getting reliable yield data (Mahul and Stutley, 2010; World Bank, 2011).

In a simplified weather index insurance contract, for example, meant to insure farmers against drought risk, rainfall data is measured at a local weather station for a period of time (World Bank, 2011). The insurer establishes the normal average rainfall in the surrounding area (threshold 1) and a minimum agronomic threshold below which plant growth would be affected (threshold 2). In the event that the realized rainfall is less than the normal average, all insured farmers registered under the respective weather station receive an indemnity payment. The payment amount is the monetized value per millimeter of rainfall below the normal average, which increases proportionately until the second threshold is crossed. In such a severe case of drought, a maximum pay-out is received by insured farmers (Giné and Yang, 2009; World Bank, 2011). Figure 1 illustrates the drought contract example.

Index insurance solves many of the problems that traditionally affect crop insurance. For example, because of relying on a variable that is verifiable and less prone to manipulation, index insurance minimizes moral hazard and adverse selection issues. Moral hazard is solved because an insured farmer has no incentive to let his crop fail to get compensation. All farmers registered under a weather station pay the same premium rate and receive indemnity payment based on similar terms, so adverse selection is also minimized. Another advantage is that administrative costs are lower in an index insurance program since 
on-farm yield-damage assessments are not necessary. The insurer can also easily access international reinsurance, particularly for the extremely severe shocks, which are difficult for a single insurance company to handle. In turn, lower transaction costs reduce the loading on premiums, making it possible to provide relatively affordable insurance instruments even to small farmers (Barnett and Mahul, 2007; World Bank, 2011; Miranda and Farrin, 2012).

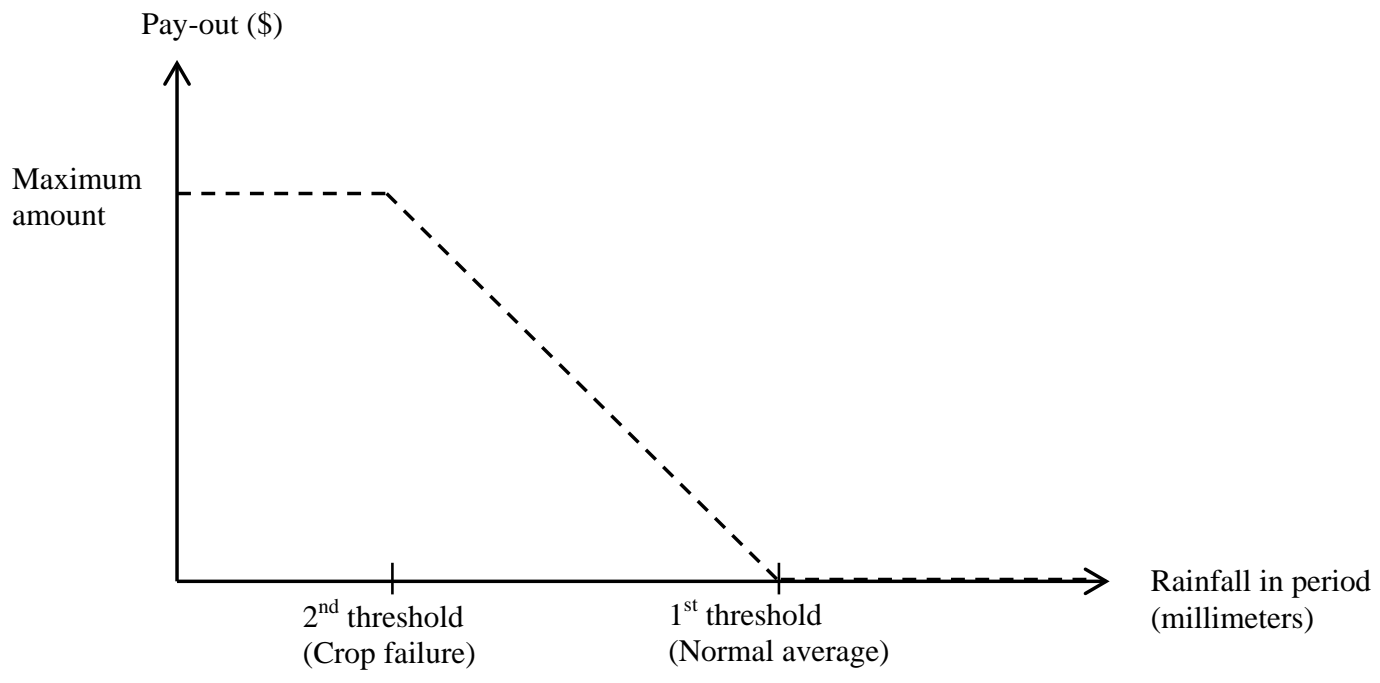

\section{Figure 1.1: Rainfall measurement and pay-out for a weather index insurance contract}

(Source: Giné and Yang, 2009)

One major limitation is that index insurance contracts are subject to basis risk - i.e. some residual risk is left with the insured farmer - which arises because the index used is not perfectly correlated with yield losses on each farm. As such, the insurance might fail to trigger a payment when the farmer actually experienced crop loss; or a payment might be triggered when no loss was experienced. This means that index insurance is not suitable for all risks and definitely not to all places (Musshoff et al., 2011; Elabed et al., 2013; Jensen et al., 2016). There are places with micro-climates or where yield losses on individual farms result to a great extent from localized risks (e.g., frost, hails, pests). In such cases crop losses will not be accurately predicted by a regional level index, and index insurance in general will not work properly. However, if carefully designed to minimize basis risk, and within the right environment, index insurance products can be effective for transferring severe weather-related risks that perpetuate poverty in 
rural areas. Furthermore, experience from a number of lower-income countries indicates that index insurance products can be used beyond the farm level, to hedge risks of intermediate agricultural-related firms and to strengthen disaster risk management at the macro level (Barnett et al., 2008; Hazell and Hess, 2010; Carter et al., 2014).

\subsection{Problem statement and objectives}

Recent years have seen an increase in the number of pilot programs on weather index insurance (WII) in developing countries. However, despite the potential benefits of WII products, voluntary uptake among small farmers has been lower than expected (Binswanger-Mkhize, 2012; Carter et al., 2014). The patterns of adoption have also been puzzling: poor households who are particularly risk averse and who could benefit the most from micro-insurance show particularly low demand. Where there is reasonable demand, often this is because premiums are heavily subsidized, or insurance is made almost mandatory by being provided in combination with credit or technical inputs (Sarris, 2013; Clarke et al., 2012; Miranda and Farrin, 2012).

This mismatch between anticipated and actual demand has attracted research on determinants of index insurance adoption. Available studies attribute the problem of low adoption to liquidity constraints, limited trust, and lack of insurance experience (e.g., Giné et al., 2008; Cole et al., 2013; Hill et al., 2013). Others cite basis risk as a major hindrance and investigate mechanisms for reducing basis risk in index insurance design (Breustedt et al., 2008; Kellner and Musshoff, 2011; Norton et al., 2013; Elabed et al., 2013; Jensen et al., 2016). A number of experimental games were also undertaken to better understand insurance demand and to educate farmers about the concepts of index insurance (e.g., Carter et al., 2008; Norton et al., 2014; Takahashi et al., 2016). However, farmers' preferences and willingness to pay for specific attributes of WII contracts have rarely been analyzed. A few studies used choice experiments to examine farmers' attitudes towards WII in developed countries (Liebe et al., 2012; Liesivaara and Myyrä, 2014). To the best of our knowledge, only two recent studies have applied this method in developing countries, namely in Ethiopia and Bangladesh (Castellani et al., 2014; Akter et al., 2016). Evidence is 
particularly limited on how farmers would respond to higher levels of insurer transparency, and provision of WII at group-level. In this study, we contribute to the literature by using the choice experimental method to explicitly analyze farmers' valuation of contract features related to basis risk, insurer transparency, and group-provision of insurance contracts.

The second research gap we identified in the literature relates to the impacts of existing WII programs. Index insurance programs are aimed not only at providing farmers with another risk management option, but also at catalyzing agricultural development through improved access to agricultural finance or increased utilization of modern technology. Yet empirical evidence on the impact of WII uptake on production decisions is limited. A few studies in this direction exist, most of them using field experiments rather than observations from actually existing WII programs. Using experimental methods, Giné and Yang (2009) found that loan-linked insurance had a negative influence on technology adoption in Malawi, which is against expectations. A few similar studies have reported a positive effect of WII on agricultural investments among smallholder farmers in Ghana, Ethiopia, and Mali (e.g., Karlan et al., 2014; Berhane et al., 2015; Elabed and Carter, 2015).

Amidst this scarce and mixed evidence it remains unclear if WII is really an appropriate tool to foster growth in smallholder agriculture. While important to understand behavioral responses in a controlled setting, results from field experiments may not always be generalizable under typical circumstances outside the experiment, where additional factors may play an important role. For instance, outside of a controlled experiment, liquidity constraints and limited access to information and markets may be more challenging issues. Therefore, studies with observational data can provide important complementary information in settings where commercial WII programs exist. Understanding how existing WII programs impact on input use and productivity is particularly relevant for agricultural policy, especially in Africa where the utilization of modern inputs and technologies remains relatively low.

To address the mentioned research gaps, the following specific objectives were developed for the study: 
i) To analyze farmers’ overall attitudes, preferences, and willingness to pay for WII.

ii) To analyze the factors influencing smallholder farmers' uptake of currently marketed WII contracts in Kenya.

iii) To evaluate the impact of WII purchase on input use and productivity among smallholder farmers in Kenya.

\subsection{Data}

\subsubsection{The Kenyan context}

Kenya's agricultural system is predominantly rain-fed, and highly vulnerable to weather variability. The country is also prone to recurrent weather disasters (e.g., droughts) that occur at least once in every five years given that $80 \%$ of the land area is either arid or semi-arid (Omoyo et al., 2015). The impacts of weather variability and climatic shocks in an agricultural-dependent country like Kenya can be substantial, since poor performance of the agricultural sector dampens growth for the whole economy. Furthermore, the government and donor agencies incur huge spending in humanitarian assistance every time there is an adverse weather event (Shiferaw et al., 2014). Therefore, there has been a need for market-based solutions to transfer part of these risks outside of rural communities and, where possible, internationally.

Thanks to technical assistance from the World Bank and the International Livestock Research Institute (ILRI), the Kenyan insurance sector started piloting index-based insurance products with a view of creating an active market for such products in the country (FSD, 2013). While many of these initiatives never went beyond the pilot stage, there have been promising examples, including ILRI's index-based livestock insurance; and the Kilimo Salama WII Program initiated by Syngenta Foundation (FSD, 2013; Jensen et al., 2016). The Kilimo Salama Program is particularly outstanding because it began as a pilot project in 2009, offering rainfall insurance to a small group of 200 farmers. By 2013, close to 200,000 farmers in Kenya, Rwanda, and Tanzania had been covered through this Program. In the Kilimo Salama Program, WII is mostly linked to agricultural loans or sold to farmers through local input dealers. The 
Program has transitioned into a commercial business since 2014, showing that with the right design and implementation, index insurance programs are capable of upscaling (Greatrex et al., 2015). Our empirical study explores farmers' preferences and the impact of WII on smallholder productivity growth, using the Kenyan context and the specific case of Kilimo Salama as an example. Further information about the Kilimo Salama Program is provided in Chapter 2.

\subsubsection{Farm survey}

The data utilized in this study was collected in 2014 among smallholder farmers in Embu County, Kenya. Embu was selected for the survey because WII products had been marketed in the area for more than five years through the Kilimo Salama Program (Sina and Jacobi, 2012). Hence, farmers' familiarity with WII was higher in Embu than in other parts of Kenya. Embu is a high potential area for agricultural production with an average rainfall of 1000-2000 millimeters per annum and a bimodal rainfall distribution. However, rainfall is highly unpredictable in this part of Kenya in terms of timing and seasonal distribution, which is a major issue affecting agricultural productivity in Embu (Ngetich et al., 2014; Omoyo et al., 2015).

To select households for the survey, we followed a multi-stage stratified sampling procedure. First, we purposively selected Embu-East sub-county, which according to the County Ministry of Agriculture, had a relatively high number of insured farmers. Embu-East has two administrative divisions, namely Kyeni and Runyenjes. Within each of these divisions we randomly selected three sub-locations (smallest administrative units). Then in each of the selected sub-locations, we interviewed all farmers who had ever been insured under the Kilimo Salama Program. To identify the “ever-insured” farmers we relied on lists provided by Kilimo Salama field staff. In addition, non-insured farmers were selected randomly in the same sub-locations. In total, 386 households were interviewed, comprising 152 "ever-insured” and 234 non-insured farmers.

The survey involved face-to-face interviews which were conducted during the long-rain (AprilAugust) season of 2014. A small team of enumerators from Egerton University, who could speak the local 
dialect, were hired to assist with the interviews. We used a carefully designed and pretested questionnaire developed for this research. In addition to a wide range of questions about agricultural production, the socioeconomic context, WII uptake, and farmers' risk attitudes and coping strategies, the questionnaire also comprised a choice experiment through which we elicited data about farmers' preferences for WII. The survey questionnaire is provided in Appendix B.

\subsection{Dissertation outline}

The next chapters of this dissertation are organized as follows. Chapter 2 addresses the first objective of the research. We provide a detailed descriptive analysis of farmers' experiences with the existing WII products, including an assessment of overall satisfaction levels. Econometric analysis of farmers' preferences is undertaken by use of a mixed logit model, which takes into account varying preferences across sample farmers. We also compute willingness to pay estimates to show relative preferences for specific contract attributes and attribute levels. The willingness to pay estimates provide a basis for suggesting improvements that could potentially make WII contracts more attractive and valuable within small-farm contexts.

Chapter 3 addresses the second and third objectives of the research. We first model the factors influencing the probability of WII uptake. Then we apply treatment-effects regressions with instrumental variables to analyze the effects of WII on the intensity of input use. Thereafter, we analyze effects of WII on productivity using the example of maize, because maize is the most important staple food crop in Kenya and widely grown in Embu. Other factors affecting the usage of purchased inputs and maize productivity are also identified.

Chapter 4 gives a brief summary of the main findings from the research. Based on those findings we draw conclusions and provide relevant recommendations for policy and also for future research. 


\title{
Chapter 2: Small Farmers’ Preferences for Weather Index Insurance: Insights from Kenya
}

\begin{abstract}
Smallholder farmers are particularly vulnerable to climate shocks but often lack access to agricultural insurance. Weather index insurance (WII) could reduce some of the problems associated with traditional, indemnity-based insurance programs, but uptake has been lower than expected. One reason is that WII contracts are not yet sufficiently tailored to the needs and preferences of smallholder farmers. This study combines survey and choice-experimental data from Kenya to analyze the experience with an existing WII program and how specific changes in contractual design might increase insurance uptake. Many smallholders struggle with fully understanding the functioning of the program, which undermines their confidence. Better training and communication are needed. Regular provision of relevant rainfall measurements and thresholds would significantly increase farmers' willingness to pay for WII. Mechanisms to reduce basis risk are also positively valued by farmers, although not to the same extent as higher levels of transparency. Finally, offering contracts to small groups rather than individual farmers could increase insurance uptake. Group contracts may help to reduce transaction costs. Farmer groups can also be important platforms for learning about complex innovations, including novel risk transfer products. While the concrete results are specific to Kenya, they provide some broader policy-relevant insights into typical issues of WII in a small-farm context.
\end{abstract}

Keywords: Climate risk, smallholder farmers, crop insurance, discrete choice experiment, Africa 


\subsection{Introduction}

Climate change will affect agricultural production through higher mean temperatures and more frequent weather extremes (Anton et al., 2013; Lesk et al., 2016). Higher variability in crop yields and food prices may increase poverty and food insecurity, especially in developing countries (Wheeler and von Braun, 2013; Brown and Kshirsagar, 2015). Smallholder farmers, who make up a large share of the world's poor and undernourished people, could suffer the most (World Bank, 2010). Often located in the tropics and subtropics, smallholders are particularly vulnerable to climate shocks, and they are usually also ill-equipped to cope with risks (Vermeulen et al., 2012). After severe weather events, small farm households often end up selling productive assets to smooth consumption (Carter and Barrett, 2006). Frequent weather extremes are also associated with risk-avoidance strategies, such as low uptakes of productivity-enhancing inputs and technologies (Dercon and Christiaensen, 2011). Thus, climate shocks can cause and perpetuate poverty traps in the small farm sector. Agricultural insurance could help, but is literally non-existent in most developing countries due to institutional constraints, including high transaction costs and issues of moral hazard and adverse selection (Hazell and Hess, 2010; de Janvry et al., 2014).

Weather index insurance (WII) is a relatively new type of financial risk transfer product, which could help to overcome some of the problems with traditional insurance schemes (Barnett and Mahul, 2007; IFAD, 2010). Unlike indemnity-based crop insurance, where an insured farmer receives compensation for the verifiable loss at the end of the growing season, WII makes claim payments based on the realization of an objectively measured weather variable (e.g., rainfall) that is correlated with production losses (Musshoff et al., 2011; World Bank, 2011). Neither the insured farmer nor the insurer can easily manipulate rainfall measurements, which reduces issues of information asymmetry. Moreover, instead of reducing effort to increase chances of compensation, farmers with WII actually have an incentive to make the best farming decisions (IFAD, 2010). In comparison to traditional insurance, WII is less expensive to administer, which can lead to more affordable contracts and faster payments to farmers, who often need the funds for timely planting in the subsequent season (Rao, 2010). 
Despite these potential benefits, voluntary uptake of index insurance products is much lower than was initially anticipated (Binswanger-Mkhize, 2012). Importantly, poor households, who are particularly risk-averse and could benefit most from novel micro-insurance products, were found to be hesitant in adopting WII, unless when premiums are subsidized or bundled with other benefits, such that insurance becomes quasi-compulsory (Clarke et al., 2012; Miranda and Farrin, 2012). This mismatch between anticipated and actual demand of smallholder farmers is attributed to liquidity constrains during planting time, limited trust, and lack of experience with formal insurance (Carter et al., 2008; Cole et al., 2013; Hill et al., 2013). Others cite basis risk or the residual risk that often remains with the insurance-holder as a major issue (Breustedt et al., 2008; Musshoff et al., 2011; Norton et al., 2013; Elabed et al., 2013; Jensen et al., 2016). Several field experimental studies were undertaken to better understand farmers' insurance demand and its determinants (Carter et al., 2008; Norton et al., 2014; Takahashi et al., 2016). However, farmers' preferences and willingness to pay for specific attributes of WII contracts have rarely been analyzed. Such knowledge could help to better adjust WII contracts and policies to the needs of smallholder farmers in different contexts. Here, we address this knowledge gap by using data from smallholder farmers in Kenya.

It would be interesting to observe how farmers actually respond to certain changes in the contractual design of a WII scheme. However, observational data with suitable variations in insurance contracts are not available. As an alternative, choice experiments can be conducted to analyze peoples’ preferences for hypothetical contract features that are not (yet) observable in the market. A few studies used choice experiments to examine farmer attitudes towards WII in developed countries, such as Germany and Finland (Liebe et al., 2012, Liesivaara and Myyrä, 2014). Two recent studies applied this method to estimate farmers' willingness to pay for WII in Ethiopia and Bangladesh (Castellani et al., 2014; Akter et al., 2016). We add to this choice experimental literature by analyzing more explicitly how farmers might react to changes in WII contracts aimed at reducing typical issues in a smallholder context. In particular, we study possible mechanisms to reduce basis risk and increase farmers' confidence in WII products. 
A typical problem that contributes to low confidence in WII is that farmers often do not fully understand when exactly a payment is triggered (Barnett and Mahul, 2007; Musshoff et al., 2011; Elabed et al., 2013). Even when the threshold level is clearly stated in the contract, this refers to a weather station located at some distance to the farm, so the insured farmer is usually not perfectly informed. A larger network of weather stations to decrease the mean distance to farms may be one mechanism to reduce basis risk. Another mechanism to improve confidence is regular communication of the weather data recorded at relevant stations. Transparent communication could also help to reduce farmers' distrust in the insurance provider. While some experimental evidence on the importance of trust in micro-insurance uptake exists (Patt et al., 2009; Cole et al., 2013), the specific influence of insurer transparency on WII demand has never been researched. We use contract features related to distance and regular communication in our choice experiment.

In addition, we analyze the possible role of insurance contracts with farmer groups instead of individual farmers. Group contracts are being proposed as a potential mechanism to increase WII uptake in the small-farm sector (Barnett and Mahul, 2007; de Janvry et al., 2014). Farmer groups could influence demand for WII through several pathways. First, groups can help to reduce transaction costs. Second, groups can be efficient channels for disseminating information about innovative technologies and products (Fischer and Qaim, 2014; Wollni and Fischer, 2015). Third, and related to the previous point, groups may provide a learning platform that increases farmers' confidence in trying-out unfamiliar insurance products (Traerup, 2012). Finally, farmer groups often involve networks that interact in various social dimensions and have norms on how to internalize idiosyncratic risks of their members (Townsend, 1995). Against this background, group WII contracts that help to mitigate covariate weather risks could have interesting complementary effects (Barnett and Mahul, 2007; Delpierre and Boucher, 2013; de Janvry et al., 2014). Empirical evidence on the effect of group contracts on farmers' willingness to adopt WII is scarce. A few studies have confirmed a positive influence of informal risk-sharing networks (Mobarak and Rosenzweig, 2012; Dercon et al., 2014). Others suggest that group dynamics and possible distrust towards other 
members might actually make group insurance less attractive than individual contracts (Vasilaky et al., 2014; McIntosh et al., 2015).

Our analysis builds on a survey and choice experiment carried out with smallholder farmers in Kenya. Farmers in Kenya already had the opportunity to gain first-hand experience with WII contracts. Since 2009, the so-called Kilimo Salama Program has provided index-based crop insurance products in various parts of the country. We briefly describe this existing program in the next section, before presenting and discussing details of the methodological approach and results.

\subsection{Weather index insurance in Kenya}

Crop production in Kenya takes place mostly under rain-fed conditions, with weather fluctuations having a great impact on productivity (Omoyo et al., 2015). Well-designed WII contracts could therefore be beneficial for development given such production uncertainties. Several pilot projects to introduce WII have been implemented with technical support from the World Bank and other development agencies. Kilimo Salama, which was launched by the Syngenta Foundation for Sustainable Agriculture, is the most widely-known and successful out of these projects (FSD, 2013). Kilimo Salama was started in 2009 as a small initiative with only 200 farmers. By 2013, the project covered close to 200,000 farmers in Kenya, Rwanda, and Tanzania, with a total sum insured of 12.3 million US dollars (IFC, 2015; Greatrex et al., 2015). While this growth within a few years is impressive, it cannot mask the fact that up till now only a small fraction of farmers has actually adopted WII. In 2014, Kilimo Salama transitioned into a commercial business under the new name “Agriculture and Climate Risk Enterprise” (ACRE). In this study, we stick to the old name because this is better known in the literature.

Kilimo Salama offers rainfall index insurance products that cover farmers against drought and excess rain. As is common for weather-based insurance schemes, Kilimo Salama relies on data from automated weather stations to monitor local rainfall. Farmers are allowed to choose the station that best represents their farm conditions. Initially, the contracts were designed for maize and wheat, but more recently products for other crops have also been developed (IFC, 2015). Contracts are sold for a crop 
season divided into three phases (early growth, flowering, and grain filling), which vary in duration and rainfall thresholds. Contracts are location-specific, and threshold (or strike) levels reflect the minimum agronomic requirements for normal plant growth during each particular phase. If the cumulative rainfall in a given phase falls below the threshold (for drought) or exceeds the threshold (for excess rain), a pay-out is triggered for all farmers holding a contract with reference to the particular weather station. The pay-out amount is calculated per millimeter of rainfall below (or above) the strike level and increases proportionately up to the maximum pay-out. However, as we learned through our survey, farmers are rarely aware of the exact details of the pay-out function, even when they purchase an insurance contract. At the end of the contract period, the sum of triggered pay-outs over the three phases is sent to farmers through mobile money transfer. This is different from traditional indemnity-based crop insurance programs, where the insurer has to physically visit the farm to assess individual crop damage.

One important element for the smooth functioning of Kilimo Salama is the existence of a vibrant mobile money network (M-PESA) that facilitates farmers' access to various financial services (Kikulwe et al., 2014; Greatrex et al., 2015). In many cases, farmers purchase WII linked to agricultural loans; in the event of unfavorable weather conditions the insurer compensates the credit institution, which then writes off the loans of affected farmers. Kilimo Salama also offers input insurance through local input dealers. In that case, the insurance premium is included in the price of purchased inputs.

In 2011, Kilimo Salama-plus was launched, which offers the option to either only insure the cost of the inputs at a lower premium or the value of the output at a higher premium. Both options are offered through local input dealers on behalf of the insurer. The dealers have technical equipment to directly transmit purchase information to an administrative server, which also automatically triggers pay-outs to farmers via M-PESA. To keep our choice experiment simple and easy to understand for farmers, our hypothetical contracts build on the output-based insurance option, as is explained in more detail below. 


\subsection{Materials and methods}

\subsubsection{Farm survey}

This study builds on primary data collected in 2014 among smallholder farms in Embu County, Kenya. Embu was chosen because WII initiatives have been implemented in that area for more than five years (Sina and Jacobi, 2012). This ensured farmers' familiarity with this type of insurance. Farmers in Embu are predominantly small-scale, and uncertainty about the timing and amount of rainfall is a serious issue in this part of Kenya (Ngetich et al., 2014).

The farm households to be surveyed were selected using a stratified sampling procedure. At first, we purposively selected Embu-East sub-county, which had a relatively high number of farmers insured under Kilimo Salama. However, even in Embu-East insurance coverage was below 10\%. Embu-East has two administrative divisions (Kyeni and Runyenjes); within each division we randomly selected three sublocations (smallest administrative units). In each of the six sub-locations, we interviewed all farmers that were insured at the time of the survey or had purchased an insurance contract in previous years. These farmers were identified through lists provided by Kilimo Salama field staff. Overall, we surveyed 152 “ever-insured” farmers. In addition, we randomly selected 234 non-insured farmers in the same six sublocations, resulting in a total sample size of 386. While we deliberately over-sampled insured farmers, the two sub-samples are representative for “ever-insured” and non-insured farmers in Embu-East.

The survey involved face-to-face interviews, which were administered with the help of a small team of local enumerators. The enumerators were students from Egerton University that we hired and trained for this research. The survey instrument included a structured questionnaire to capture socioeconomic data at farm and household level, including risk preferences, past experiences with weather shocks, and attitudes towards the existing WII contracts. In addition, each sample farmer participated in a carefully-designed choice experiment. In this choice experiment, farmers were asked to make selections between various hypothetical WII insurance options to better understand possible responses to contract changes. Details of the choice experiment are explained in the following. 


\subsubsection{Discrete choice experiment}

We developed and used a discrete choice experiment (DCE) to evaluate subjective preferences of farmers for WII contracts. In particular, we want to assess how farmers value specific contract attributes and trade-off between different attribute levels, which is not possible with other common preference elicitation methods such as contingent valuation (Adamowicz et al., 1998). The theoretical basis for DCEs is Lancaster's consumer choice theory, which postulates that an individual derives utility from the different attributes of a good (Louviere et al., 2000). DCEs are also consistent with random utility theory, which suggests that, given a finite set of alternatives, a rational individual will always prefer the alternative that yields the highest utility (Adamowicz et al., 1998). DCEs are frequently applied in agriculture and environmental valuation to study consumer and producer preferences in multi-attribute choice problems (e.g., Hanley et al., 2001; Schipmann and Qaim, 2011; Veettil et al., 2011; Kouser and Qaim, 2013). But, as explained, choice-experimental methods have not yet been widely used to analyze farmer preferences for WII.

\subsubsection{Experimental design}

For designing the DCE, we first identified contract attributes of possible interest in the WII context through a review of the relevant literature (Giné and Yang, 2009; Heimfarth and Musshoff, 2011; Liebe et al., 2012; Delpierre and Boucher, 2013; Elabed et al., 2013). Then, we carried out focus group discussions with farmers in Kenya and also consulted local insurance agents and agricultural extension officers to narrow down the list of possible attributes to those most meaningful in a smallholder context. In order not to overburden participants in the experiment, we eventually decided to use five contract attributes, as shown in Table 2.1. 
Table 2.1: Attributes of WII contracts used in the choice experiment

\begin{tabular}{|c|c|c|c|c|c|c|}
\hline \multirow{2}{*}{$\begin{array}{l}\text { Attribute } \\
\text { Premium rate }\end{array}$} & \multicolumn{6}{|c|}{ Attribute levels } \\
\hline & $2 \%$ & $5 \%$ & $7 \%$ & $10 \%$ & $15 \%$ & $20 \%$ \\
\hline Strike level & $-10 \%$ & $-20 \%$ & $-40 \%$ & $\pm 10 \%$ & $\pm 20 \%$ & $\pm 40 \%$ \\
\hline $\begin{array}{l}\text { Distance to weather } \\
\text { station }\end{array}$ & \multicolumn{2}{|c|}{5 km (ward radius) } & \multicolumn{2}{|c|}{20 km (district radius) } & \multicolumn{2}{|c|}{50 km (county radius) } \\
\hline Transparency & \multicolumn{3}{|c|}{$\begin{array}{l}\text { Weekly text messages and radio } \\
\text { broadcast of recorded rainfall }\end{array}$} & \multicolumn{3}{|c|}{$\begin{array}{l}\text { No text message or radio broadcast of } \\
\text { recorded rainfall }\end{array}$} \\
\hline Contracted party & \multicolumn{2}{|c|}{ Individual farmer } & \multicolumn{2}{|c|}{ Small group (10 farmers) } & \multicolumn{2}{|c|}{ Large group (100 farmers) } \\
\hline
\end{tabular}

"Premium rate" is the fee charged for insurance coverage. This is expressed as a percentage of the maximum pay-out (expected value of harvest per acre), irrespective of the type of crop cultivated. In the existing WII contracts, premium rates are calculated based on the historical frequency of certain weather events. For instance, severe droughts in Kenya occur every ten years, so the average premium charged in existing contracts is $10 \%$. Yet, the rates are adjusted to local weather conditions, where shocks may occur more or less often. In the Kilimo Salama Program, premium rates range from 5-25\% depending on the location (IFC, 2015). We included six levels ranging from 2-20\% in the DCE, in order to predict farmers' responsiveness to changing prices.

Apart from the premium rate, which is treated as numerical, all the other attributes were effectscoded, thus ensuring that the effect of reference levels is not correlated with the intercept (Bech and GyrdHansen, 2005). "Strike level”, refers to the percentage deviation in rainfall at which the index triggers a pay-out to the insurance-holder in a particular phase of the crop season. We chose to include six levels, where a negative sign (e.g., $-20 \%$ ) refers to drought contracts, and double signs (e.g., $\pm 20 \%$ ) refer to contracts that insure both drought and excess rainfall. Strike levels indicate the magnitude of loss (mild, moderate, or severe) that farmers have to personally manage before a pay-out is triggered. Strike levels also determine how frequently insured farmers will receive compensation over the years. Higher levels (say $40 \%$ rainfall deviation) decrease the probability of compensation, hence making insurance contracts more affordable. But this also reduces eligibility and frequency of payments, since payments will only be 
triggered by rare but extremely severe losses (Rao, 2010; Clarke et al., 2012). The tick size (i.e., the payment per millimeter of rainfall deviation) was not varied across attribute levels.

The third attribute is distance from the farm to the weather station, which we use as a proxy for basis risk. With shorter distances, pay-outs will be more closely correlated with actual yield losses on the farm (Heimfarth and Musshoff, 2011). Distance also signifies the radius of the insurance zone. Insured farmers within this zone pay the same premium rate and receive pay-outs at the same time (IFAD, 2010). For this attribute we considered three levels, as shown in Table 2.1.

The fourth attribute relates to insurer transparency. In two attribute levels, we differentiate between transparent and non-transparent contracts, referring to the weather information provided to farmers. For transparent contracts, insured farmers would receive weekly text messages from the insurer, summarizing rainfall measurements at the reference weather station, required measurements for a pay-out, and whether a threshold for pay-out has actually been reached in that phase. This information would be publicly verifiable, by comparing with radio broadcasts about local weather facilitated by the national meteorological department. In the Kilimo Salama Program, such information is currently not provided to farmers, but the proposed intervention would be technically feasible without much extra cost.

The last attribute refers to the "contracted party”, which allows us to analyze farmer preferences for individual versus group contracts. Currently, Kilimo Salama sells contracts only to individuals. As explained, group contracts may potentially be attractive for farmers to reduce transaction costs and benefit from mutual learning and broader risk-sharing arrangements. But the effectiveness of groups may depend on group size (Ligon et al., 2002; Fischer and Qaim, 2014). Hence, we distinguish between small groups (10 members) and large groups (100 members) in different attribute levels. In Kenya, a minimum of 10 members is required for a group to be legally registered.

The next step in the DCE design was to come up with meaningful choice alternatives from varying combinations of attributes and attribute levels. The generic nature of the research problem prompted the use of an unlabeled experiment (Hensher et al., 2005). A full factorial design based on the five attributes and associated attribute levels gives a total of $648\left(2^{1} \times 3^{2} \times 6^{2}\right)$ possible combinations. Using 
SAS macros (Kuhfeld, 2010), we developed 12 generic choice sets with a calculated D-efficiency of 0.79. To prevent fatigue and resulting inefficiency in answering, these 12 choice sets were randomly divided into three blocks, and only one of these blocks was randomly assigned to each participating farmer. That is, each farmer participated in four choice sets by choosing one out of three hypothetical insurance contracts. Every choice set also included a "no-insurance" opt-out choice, which farmers could select when none of the contract choices was satisfactory to them. This design makes it possible to interpret welfare effects resulting from the proposed contract modifications (Hanley et al., 2001).

Prior to presenting the choice sets, the different attributes and attribute levels were explained to farmers in their local language. The choice cards also had shortened texts and pictorial representations of the attribute levels to facilitate understanding. An example of a choice set presented to farmers is shown in Figure 2.1.

\begin{tabular}{|c|c|c|c|c|}
\hline $\begin{array}{c}\text { Threshold } \\
\text { rainfall } \\
\text { (strike level) }\end{array}$ & Transparency & $\begin{array}{c}\text { Distance to the } \\
\text { nearest weather } \\
\text { station }\end{array}$ & $\begin{array}{c}\text { Contracted } \\
\text { party }\end{array}$ & Premium rate \\
\hline \multicolumn{5}{|c|}{ Choice card 1A } \\
\hline$-40 \%$ & $\begin{array}{l}\text { No text message or } \\
\text { open radio broadcast } \\
\text { of recorded rainfall }\end{array}$ & $\begin{array}{c}5 \mathbf{k m} \\
\text { (ward radius) }\end{array}$ & $\begin{array}{l}\text { Large group } \\
\text { (100 farmers) }\end{array}$ & $\begin{array}{l}5 \% \text { of expected } \\
\text { harvest }\end{array}$ \\
\hline \multicolumn{5}{|c|}{ Choice card $1 B$} \\
\hline $\begin{array}{l}\text { mait } \\
\pm 40 \%\end{array}$ & $\begin{array}{l}\text { Weekly texts and } \\
\text { open radio broadcast } \\
\text { of recorded rainfall }\end{array}$ & $\begin{array}{l}50 \mathrm{~km} \\
\text { (county radius) }\end{array}$ & $\begin{array}{c}\text { Small group } \\
\text { (10 farmers) }\end{array}$ & 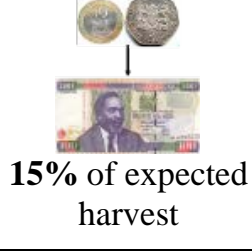 \\
\hline \multicolumn{5}{|c|}{ Choice card 1C } \\
\hline$-10 \%$ & $\begin{array}{l}\text { No text message or } \\
\text { open radio broadcast } \\
\text { of recorded rainfall }\end{array}$ & (district radius) & $\begin{array}{c}\text { Individual } \\
\text { farmer }\end{array}$ & 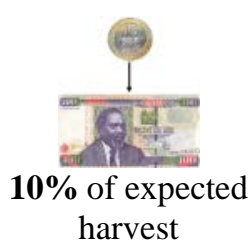 \\
\hline choose nor & the above three WII co & $\begin{array}{l}\text { Choice 1D } \\
{\left[\begin{array}{c}3 \\
\end{array}\right.}\end{array}$ & & \\
\hline
\end{tabular}

Figure 2.1: Example of a choice set 


\subsubsection{Econometric model}

The choice data were analyzed using mixed logit (ML), a popular model in discrete choice analysis (Train, 2003). ML has several advantages over standard logit models. First, it allows utility parameters to vary over decision-makers rather than being fixed, hence accommodating for preference heterogeneity in the sample. Second, it relaxes the independence of irrelevant alternatives (IIA) assumption in standard logit models. In our case, Hausman specification tests showed that the IIA assumption was violated, so that the standard logit model would have produced biased estimates. Third, ML allows for correlation of unobserved factors over choice situations. In our experiment, each farmer responded to four choice sets, meaning that individual-specific characteristics did not vary. Correlation over choice sets could also occur due to learning effects or fatigue among respondents (Train, 2003; Hensher et al., 2005).

The ML models were run in STATA using a maximum simulated likelihood estimator (Hole, 2007). We assumed a lognormal distribution for the premium rate attribute, allowing us to restrict the coefficient sign to be negative (rational farmers will always prefer a lower premium, holding other things constant) while still being able to account for preference heterogeneity (Hole and Kolstad, 2012). The coefficients for the non-monetary attributes were assumed to be independent and normally distributed because the direction of preferences could not be determined prior to estimation.

We start by first specifying a main-effects model, assuming preference heterogeneity for all attributes. The simplified empirical model is expressed as:

$$
y_{n t}=\alpha_{n}+\beta_{n} p_{n t}+\gamma_{n}^{\prime} x_{n t}^{\prime}
$$

where $y_{n t}$ is a binary variable that takes a value of one if farmer $n$ chooses a WII contract in choice scenario $t$, and zero otherwise. $\alpha$ is an alternative specific constant (ASC), and $\beta$ and $\gamma^{\prime}$ are parameters to be estimated for the premium rate $\left(p_{n t}\right)$ and other contract attributes $\left(X_{n t}^{\prime}\right)$ respectively. The ASC captures the average effect of unobserved factors on utility (Train, 2003). In our specification, the ASC is defined such that it tells us how farmers value the no-contract option when observed factors are controlled 
for. That is, a negative ASC coefficient reveals a negative general attitude towards the non-contract option (a positive preference for WII contracts) and vice versa.

Next, we add interaction terms to analyze the influence of farmer-specific characteristics on contract preferences and thus better understand causes of preference heterogeneity. These extended models are specified as follows:

$y_{n t}=\alpha_{n}+\beta_{n} p_{n t}+\gamma_{n}^{\prime} x_{n t}^{\prime}+\delta_{n 1}\left(A S C \times W I I_{n}^{2014}\right)+\delta_{n 2}\left(A S C \times W I I_{n}^{2013}\right)+\delta_{n 3}\left(A S C \times W I I_{n}^{\text {before }}\right)$

$y_{n t}=\alpha_{n}+\beta_{n} p_{n t}+\gamma_{n}^{\prime} x_{n t}^{\prime}+\lambda_{n}^{\prime}\left(A S C \times z_{n}^{\prime}\right)$

where $W I I_{n}^{2014}, W I I_{n}^{2013}$, and $W I I_{n}^{\text {before }}$ are dummy variables that take a value of one if the household had last purchased WII in 2014, 2013, or any previous year, respectively. Thus, we can evaluate the influence of previous contract experience and drop-out on current contract preferences. In equation [2.3], $Z_{n}^{\prime}$ is a vector of socio-economic factors that are expected to influence farmers' demand for WII.

Finally, by working out the total derivative of utility $\left(U_{n t}\right)$ with respect to changes in the premium rate and other contract attributes $\left[d U_{n t}=\beta_{n} d p+\gamma_{n}^{\prime} d x^{\prime}\right]$ and setting this expression equal to zero, we can solve for:

$$
\frac{d p}{d x_{k}}=-\frac{\gamma_{n k}}{\beta_{n}}=W T P_{n k}
$$

which is the marginal willingness to pay (WTP) of farmer $n$ for a change in attribute $x_{k}$ (Hensher et al., 2005). Given that the premium rate is log-normally distributed, we use the median parameter which is less sensitive than the mean (Meijer and Rouwendal, 2006). The median estimate for the premium rate is calculated as $-\exp \left(\beta_{n}\right)$ (Hole, 2007). 


\subsection{Results and discussion}

We first introduce sample descriptive statistics and farmers' experience with the existing Kilimo Salama insurance scheme, before presenting and discussing results from the model estimates with the choice experimental data.

\subsubsection{Socio-economic characteristics}

Table 2.2 presents descriptive statistics of socio-economic characteristics for the full sample of farmers, as well as separately for the sub-samples of ever-insured and non-insured farmers. Overall, sample farmers from Embu County are typical smallholders with an average farm size of around two acres. Statistically significant differences between the sub-samples are observed for sex, age, farming experience, and occupation of the household head. Female-headed households are more likely to purchase insurance than male-headed households. Furthermore, insured farmers are older and more experienced than their non-insured colleagues, and they derive a larger share of their income from farming. This suggests that, to some extent, insurance may be a substitute for income diversification, which otherwise tends to be a common strategy to cope with risk. Farmers with access to WII training and those who have been organized in farmer groups for a longer period of time are also more likely to purchase insurance.

Farmers were also asked how willing they are to take risks in their farming decisions using a scale of $1=$ very risk-averse to $10=$ very risk-loving. This direct question about farmers’ perception of their risk behavior is an alternative to more comprehensive lotteries that can also be used to elicit risk attitudes. Dohmen et al. (2011) argued that farmers sometimes overstate their risk preference (understate their risk aversion) when asked directly, but that in terms of comparing relative risk attitudes answers to direct questions are equally reliable as lotteries. The last row in Table 2.2 reveals that average risk preferences are indeed relatively high. However, as the same question was used for all sample farmers, relative comparisons should be in order. Interestingly, we do not observe a statistically significant difference in risk attitudes between ever-insured and non-insured farmers. 
Table 2.2: Socio-economic characteristics of sample farmers

\begin{tabular}{lccc}
\hline Variables & $\begin{array}{c}\text { Full sample } \\
(\mathrm{n}=386)\end{array}$ & $\begin{array}{c}\text { Ever-insured } \\
(\mathrm{n}=152)\end{array}$ & $\begin{array}{c}\text { Non-insured } \\
(\mathrm{n}=234)\end{array}$ \\
\hline Male household head (\%) & $67.9(46.8)$ & $58.6(49.4)$ & $73.9^{* * *}(44.0)$ \\
Education of farmer (years) & $8.2(4.0)$ & $8.2(4.0)$ & $8.2(4.0)$ \\
Age of farmer (years) & $52.1(14.6)$ & $53.7(13.1)$ & $51.1^{*}(15.4)$ \\
Farming experience (years) & $26.8(16.2)$ & $29.1(15.7)$ & $25.3^{* *}(16.4)$ \\
Household size (persons) & $4.6(1.9)$ & $4.6(2.0)$ & $4.5(1.9)$ \\
Farming as primary occupation (\%) & $92.0(27.2)$ & $94.7(22.3)$ & $90.2^{* * *(29.8)}$ \\
Off-farm secondary occupation (\%) & $33.4(47.2)$ & $29.0(45.4)$ & $36.3^{* * *}(48.1)$ \\
Farm size (acres) & $2.1(1.9)$ & $2.4(2.4)$ & $1.9^{* * *}(1.5)$ \\
Land title (\%) & $66.4(47.2)$ & $74.7(43.5)$ & $61.0^{* * *(48.8)}$ \\
Share of farm income (\%) & $67.2(32.7)$ & $72.0(31.1)$ & $64.1^{* *}(33.4)$ \\
Total annual income ('000 Ksh) & $186.4(370.9)$ & $158.4(216.6)$ & $204.6(442.8)$ \\
Share of land under maize (\%) & $46.1(17.5)$ & $49.5(18.7)$ & $43.9^{* * *}(16.3)$ \\
Received WII training in 2013 (\%) & $41.2(49.3)$ & $61.8(48.7)$ & $27.8^{* * *}(44.9)$ \\
WII trainings in 2013 (number of contacts) & $2.3(8.5)$ & $3.5(10.5)$ & $1.6 * *(6.8)$ \\
Group membership (\%) & $88.1(32.4)$ & $90.8(29.0)$ & $86.3(34.4)$ \\
Years in group & $11.2(12.8)$ & $14.2(13.4)$ & $9.2^{* * * *(12.1)}$ \\
Access to farming loan (\%) & $20.2(40.2)$ & $23.0(42.2)$ & $18.4(38.8)$ \\
Farming loan received in 2013 ('000 Ksh) & $28.2(78.1)$ & $15.2(23.0)$ & $28.2(78.1)$ \\
Satisfaction with WII (1=very dissatisfied, & $3.4(0.5)$ & $3.5(0.6)$ & $3.3^{* * *(0.4)}$ \\
5=very satisfied) & $43.6(12.5)$ & $44.8(12.6)$ & $42.8(12.4)$ \\
Distance to weather stations (km) & $6.75(2.87)$ & $6.82(2.90)$ & $6.71(2.86)$ \\
Risk preference (1=risk averse, 5=neutral, 10= & & &
\end{tabular}

Notes: Mean values are shown with standard deviations in parentheses.

$* * *, * *, *$ indicate difference in means between sub-samples is statistically significant at $1 \%, 5 \%$, and $10 \%$ level, respectively.

Table 2.3 outlines the main agricultural risks encountered by farmers in the study area. A five-year recall period was used to enhance reliability in respondents' answers. In addition to asking respondents about the frequency of events, they also had to rate the severity of shocks based on experienced losses, using a four-point Likert scale ( $1=$ no effect, $2=$ mild, $3=$ =severe, $4=$ =very severe). Over $80 \%$ of the farmers were affected by input and output price shocks, drought, and crop pests during the last five years. Other weather-related shocks, such as excess rain, frost, and hailstorms, were more localized, and also occurred less often. 
Table 2.3: Farmers' experience with agricultural shocks during the past five years

\begin{tabular}{lccc}
\hline Agricultural risks & $\begin{array}{c}\text { Farmers affected } \\
(\%)\end{array}$ & $\begin{array}{c}\text { Frequency } \\
\text { (past 5 years) }\end{array}$ & $\begin{array}{c}\text { Severity } \\
\text { (scale:1-4) }\end{array}$ \\
\hline Input price hike & 88.6 & $4.2(1.2)$ & $3.1(0.7)$ \\
Output price drop & 85.2 & $4.1(1.2)$ & $3.0(0.7)$ \\
Drought/insufficient rain & 85.2 & $3.0(1.2)$ & $3.0(0.7)$ \\
Pests and diseases & 84.7 & $3.8(1.6)$ & $2.9(0.8)$ \\
Excess rain & 23.6 & $1.7(1.1)$ & $3.0(0.8)$ \\
Frost & 22.5 & $3.3(1.6)$ & $2.4(0.8)$ \\
Hail storms & 9.6 & $1.4(0.8)$ & $2.0(1.1)$ \\
Wildlife problem & 6.5 & $3.5(1.8)$ & $2.8(0.8)$ \\
\hline
\end{tabular}

Notes: Mean values are shown with standard deviations in parentheses.

\subsubsection{Farmers’ experience with existing WII}

We now look at experiences with the existing WII in the Kilimo Salama Program, based on farmers' responses to the survey questions. Table 2.4 shows that the number of insured farmers has increased since 2009, when WII started as a small pilot project. However, the number of insured farmers has not further increased since 2012, and has actually fallen in 2014. Similarly, the number and share of insured farmers who received payments have declined since 2012. The lower share of farmers paid in 2013 may possibly have contributed to lower insurance purchase in 2014. Yet the majority (62\%) of all ever-insured farmers has been compensated at least once since the start of the program.

Table 2.4: Number of farmers who purchased WII and received payment (2009-2014)

\begin{tabular}{lccc}
\hline Year & $\begin{array}{c}\text { Farmers who purchased } \\
\text { WII (number) }\end{array}$ & $\begin{array}{c}\text { Farmers who received } \\
\text { payment (number) }\end{array}$ & $\begin{array}{c}\text { Share of insured farmers } \\
\text { who received payment (\%) }\end{array}$ \\
\hline 2009 & 14 & 4 & 2.6 \\
2010 & 35 & 16 & 10.5 \\
2011 & 54 & 23 & 15.1 \\
2012 & 88 & 55 & 36.2 \\
2013 & 86 & 26 & 17.1 \\
2014 & 60 & 1 & 0.7 \\
Overall (in & 152 & 94 & 61.8 \\
any year) & & & \\
\hline
\end{tabular}


Farmers' responses reveal that actual insurance payments do not always coincide with their own assessment of yield losses. Differences may be due to basis risk, but they contribute to a lower level of confidence from the farmers' point of view. Figure 2.2 illustrates that in the early years of the WII program several farmers had received pay-outs without having experienced significant yield losses. It is possible that the insurance program paid more generously in the beginning to encourage more farmers to participate in subsequent years. However, in 2013, when many farmers experienced crop losses due to low rainfalls, the index failed to trigger a pay-out. As indicated above, this may have contributed to lower insurance uptake in 2014.

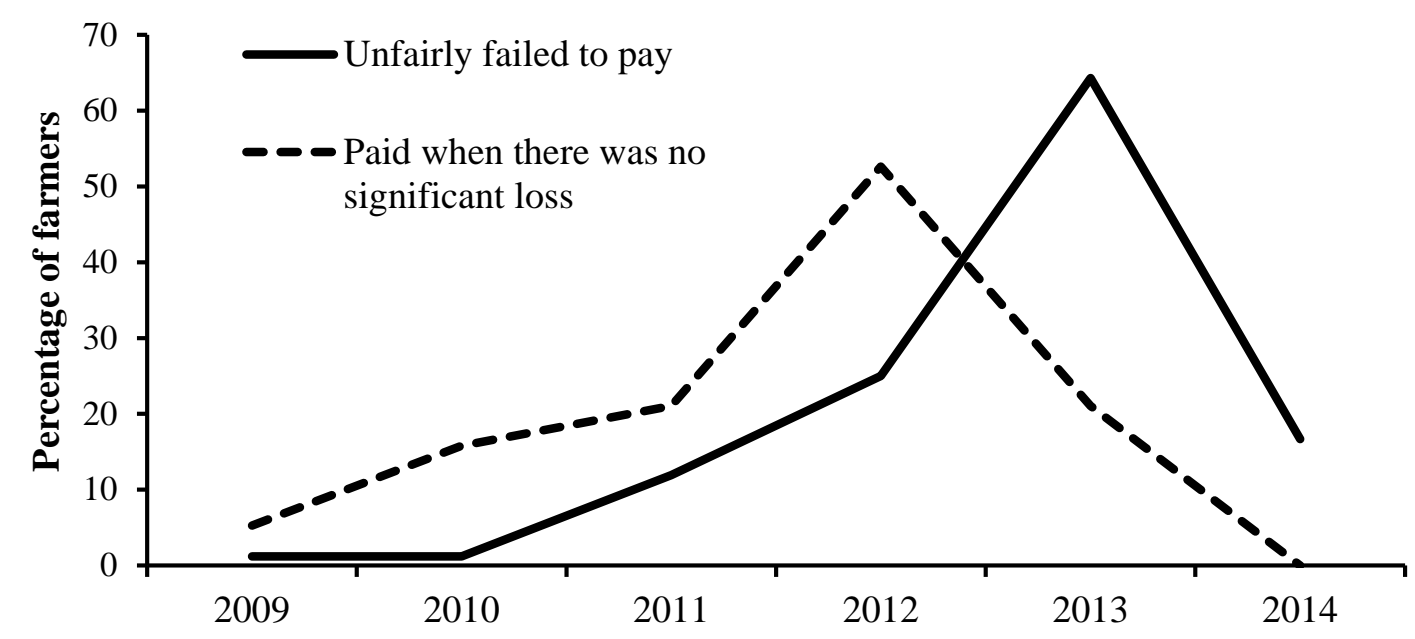

Figure 2.2: Insurance payment in "good" and “bad” years

Some of the ever-insured farmers purchased insurance in several years, others only in one year. The average number of years that farmers in this sub-sample were insured is 2.2 (out of the six years considered). Dropping-out is not uncommon, indicating that not all farmers are fully satisfied with their WII experience. In the survey, we assessed the farmers' level of satisfaction, using a list of 22 statements. Farmers were asked whether they agree or disagree with each statement based on a five-point Likert scale ranging from "completely disagree" to "completely agree”. As most farmers in our sample were aware of WII and had some opinion, the same questions were asked to all respondents, not only those who had ever 
purchased insurance themselves. Out of the 22 responses for each farmer, we calculated mean satisfaction levels, as summarized in Figure 2.3. The majority of the farmers are in the "neural" category, meaning that they are neither particularly satisfied nor dissatisfied with the WII program. Yet, further disaggregation shows that mean levels of satisfaction are higher among those who had ever purchased insurance themselves than among the non-insured. Overall, this analysis suggests that most farmers have neutral or positive attitudes towards WII in general, but that there is scope for further improvement in the insurance products.

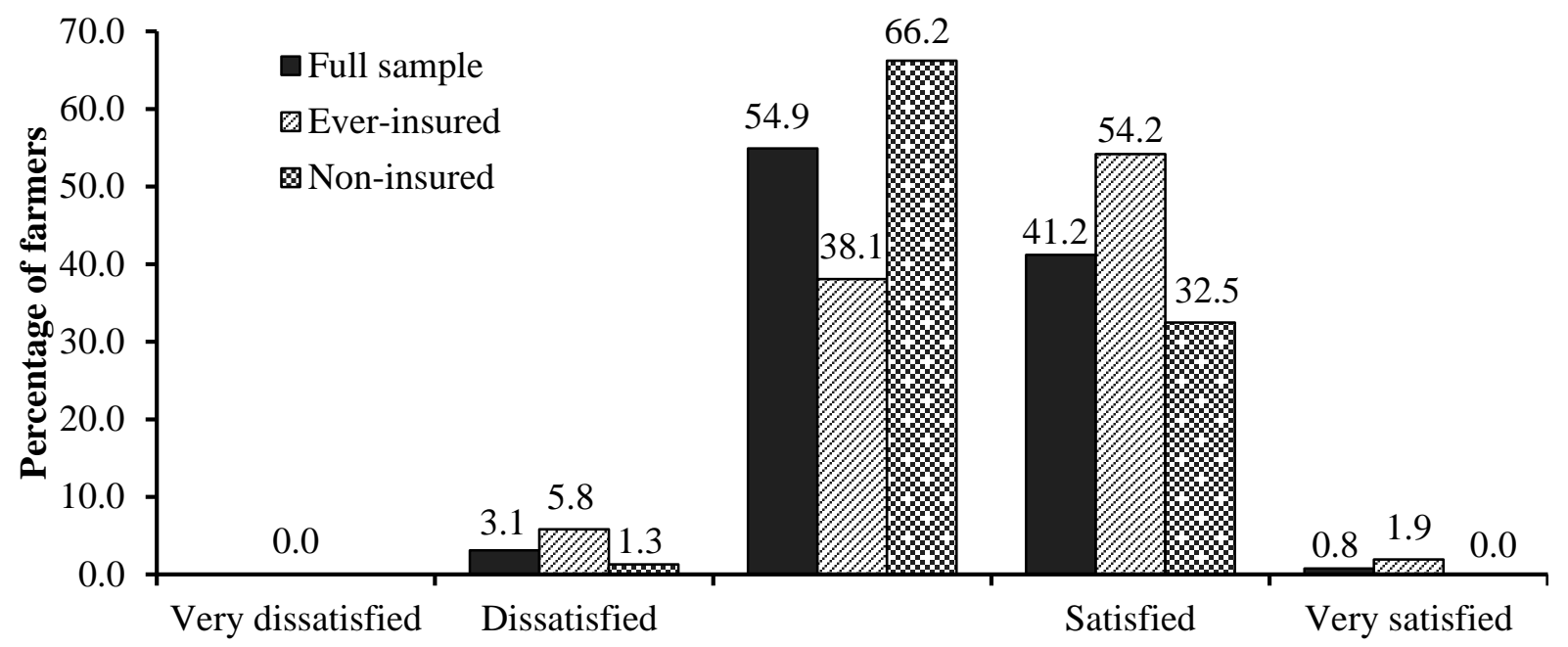

Figure 2.3: Farmers' overall satisfaction with the existing WII program

\subsubsection{Choice-experimental results}

We now present and discuss results from the DCE. Model (1) in Table 2.5 shows the ML estimates of the main-effects model without interaction terms. Most of the mean parameters are statistically significant with expected signs, suggesting that the chosen contract attributes are relevant for farmers in this context. Most of the standard deviation parameters, which are shown in the lower part of Table 2.5, are significant as well, pointing at considerable preference heterogeneity.

In model (1), the mean parameter for the ASC is negative, suggesting that farmers have a positive general attitude towards WII contracts. The premium rate coefficient is negative, meaning that farmers 
prefer lower-priced over higher-priced insurance contracts, holding other contract attributes constant. For the strike level, $-10 \%$ is the reference against which the other coefficients can be compared. The coefficient for $-20 \%$ is not statistically significant. However, the coefficient for $-40 \%$ is statistically significant. The negative sign indicates that farmers have a preference for pay-outs already starting at lower absolute threshold levels. The coefficients for $\pm 20 \%$ and $\pm 40 \%$ are positive and significant, suggesting that farmers value insurance that covers excess rainfall in addition to drought. The coefficient for $\pm 10 \%$ is insignificant, which may be due to the fact that excess rain in moderate dimensions is often less harmful for crop yields. More heavy excess rain, however, can be quite damaging, as farmers' responses in Table 2.3 above have shown. This is in line with the estimation results in Table 2.5.

The positive and significant coefficient for insurer transparency reveals a strong farmer preference for receiving regular text messages about rainfall measurements as part of the insurance contract. This result confirms that information transparency and regular communication can increase farmers' confidence in WII products, which was also pointed out by Patt et al. (2009). Concerning distance to the weather station, where $5 \mathrm{~km}$ is the reference; the negative and significant coefficient for the $50 \mathrm{~km}$ alternative shows that farmers prefer shorter distances that are associated with lower basis risk. Currently the average distance to the weather stations in our sample of farmers is $44 \mathrm{~km}$ (Table 2.1). The estimation results suggest that insurance uptake could be higher with more weather stations installed. Previous research also showed that reducing basis risk can be an important way of increasing the attractiveness of WII contracts (Musshoff et al., 2011; Norton et al., 2013). 
Table 2.5: Estimated model results for weather index insurance preferences

\begin{tabular}{|c|c|c|c|c|c|c|}
\hline \multirow{2}{*}{$\begin{array}{l}\text { Variables } \\
\text { Mean parameters }\end{array}$} & \multicolumn{2}{|l|}{ Model (1) } & \multicolumn{2}{|l|}{ Model (2) } & \multicolumn{2}{|l|}{ Model (3) } \\
\hline & & & & & & \\
\hline ASC (1=no insurance) & $-7.54 * * *$ & $(1.72)$ & $-9.53^{* * *}$ & $(2.46)$ & 4.25 & (3.93) \\
\hline Premium rate (\%) & $-5.39 * * *$ & $(2.01)$ & $-5.26 * * *$ & (1.86) & $-5.50 * * *$ & (1.86) \\
\hline Strike level - 20\% & -0.16 & $(0.11)$ & -0.16 & $(0.11)$ & -0.15 & $(0.11)$ \\
\hline$-40 \%$ & $-0.44 * * *$ & $(0.11)$ & $-0.43^{* * *}$ & $(0.11)$ & $-0.45 * * *$ & $(0.12)$ \\
\hline $\pm 10 \%$ & -0.01 & $(0.10)$ & -0.01 & $(0.10)$ & -0.01 & $(0.10)$ \\
\hline $\pm 20 \%$ & $0.18^{*}$ & $(0.10)$ & $0.17 *$ & $(0.10)$ & $0.17 *$ & $(0.10)$ \\
\hline $\pm 40 \%$ & $0.20 *$ & $(0.11)$ & $0.19 *$ & $(0.11)$ & $0.21^{*}$ & $(0.11)$ \\
\hline Transparency (1=weekly texts) & $0.85^{* * *}$ & $(0.08)$ & $0.86^{* * *}$ & $(0.08)$ & $0.86^{* * *}$ & $(0.08)$ \\
\hline Distance to station $50 \mathrm{~km}$ & $-0.27 * * *$ & $(0.07)$ & $-0.26 * * *$ & $(0.07)$ & $-0.27 * * *$ & $(0.07)$ \\
\hline $20 \mathrm{~km}$ & 0.08 & $(0.06)$ & 0.07 & $(0.07)$ & 0.08 & $(0.06)$ \\
\hline Contracted party small group & $0.25^{* * *}$ & $(0.08)$ & $0.26^{* * *}$ & $(0.08)$ & $0.25^{* * *}$ & $(0.08)$ \\
\hline large group & $-0.33 * * *$ & $(0.09)$ & $-0.33 * * *$ & $(0.09)$ & $-0.33 * * *$ & $(0.09)$ \\
\hline $\mathrm{WII}^{2014} \times$ ASC & & & -1.23 & (1.51) & & \\
\hline $\mathrm{WII}^{2013} \times$ ASC & & & -1.89 & $(1.60)$ & & \\
\hline WII ${ }^{\text {before }} \times$ ASC & & & $2.67 *$ & (1.49) & & \\
\hline Satisfaction (scale:1-5) × ASC & & & & & $-2.15^{*}$ & (1.12) \\
\hline Risk-attitude (scale:1-10) $\times$ ASC & & & & & $-0.51^{* * *}$ & $(0.20)$ \\
\hline Received WII training $\times$ ASC & & & & & $-3.22 * *$ & (1.54) \\
\hline Education $\times$ ASC & & & & & 0.0004 & (0.13) \\
\hline Female $\times$ Education $\times$ ASC & & & & & $0.30 * *$ & $(0.12)$ \\
\hline Group membership × ASC & & & & & $-2.64 * *$ & $(1.25)$ \\
\hline Off-farm occupation $\times$ ASC & & & & & -2.61 & (3.21) \\
\hline Larger farm $(1=$ if $\geq \bar{x}) \times$ ASC & & & & & $1.93^{*}$ & (1.14) \\
\hline Std. deviation parameters & & & & & & \\
\hline ASC & $3.76^{* * *}$ & $(0.88)$ & $5.03^{* * *}$ & (1.32) & $3.66^{* * *}$ & $(0.95)$ \\
\hline Premium rate (\%) & $4.29 * * *$ & $(0.83)$ & 0.20 & $(0.31)$ & 0.16 & $(0.37)$ \\
\hline Strike level - 20\% & 0.15 & $(0.37)$ & 0.39 & $(0.25)$ & $0.42 *$ & $(0.23)$ \\
\hline$-40 \%$ & 0.38 & $(0.24)$ & 0.05 & $(0.25)$ & 0.04 & $(0.25)$ \\
\hline $\pm 10 \%$ & 0.07 & $(0.24)$ & 0.21 & $(0.21)$ & 0.10 & $(0.25)$ \\
\hline $\pm 20 \%$ & 0.13 & $(0.24)$ & 0.09 & $(0.38)$ & 0.13 & $(0.26)$ \\
\hline $\pm 40 \%$ & 0.15 & $(0.25)$ & $0.62 * * *$ & (0.09) & $0.60 * * *$ & $(0.09)$ \\
\hline Transparency (1= weekly texts) & $0.60 * * *$ & $(0.09)$ & $0.45^{* * *}$ & $(0.11)$ & $0.49 * * *$ & $(0.11)$ \\
\hline Distance to station $50 \mathrm{~km}$ & $0.48^{* * *}$ & $(0.11)$ & $0.30 * *$ & $(0.13)$ & 0.24 & $(0.17)$ \\
\hline $20 \mathrm{~km}$ & 0.22 & $(0.16)$ & $0.79 * * *$ & $(0.12)$ & $0.81^{* * *}$ & $(0.12)$ \\
\hline Contracted party small group & $0.78^{* * *}$ & $(0.12)$ & $1.04 * * *$ & $(0.13)$ & $1.03^{* * *}$ & $(0.12)$ \\
\hline large group & $1.00^{* * *}$ & $(0.12)$ & $4.33^{* * *}$ & $(0.79)$ & $4.33^{* * *}$ & (0.83) \\
\hline Log likelihood & -1490.76 & & -1489.72 & & -1474.11 & \\
\hline Chi-squared & $279.12^{* * *}$ & & $278.75^{* * *}$ & & $240.55^{* * *}$ & \\
\hline
\end{tabular}

Notes: The number of observations in all three models is 6176. Coefficient estimates are shown with standard errors in parenthesis. The reference values for the effects-coded contract attributes are $-10 \%$ strike level, no text message, $5 \mathrm{~km}$ distance, and individual contract. ${ }^{* *},{ }^{* *}, *$ indicate statistically significant at the $1 \%, 5 \%$, and $10 \%$ level, respectively. 
Regarding group insurance, results in Table 2.5 show that small-group contracts are more likely to be chosen over individual contracts, whereas large-group contracts have a lower probability of being chosen. This implies that offering group contracts could motivate more farmers to take up WII, which is consistent with recent findings from Tanzania and Ethiopia (Traerup, 2012; Dercon et al., 2014). However, it also becomes evident that structural aspects such as group size matter, as larger groups may be associated with lower levels of group cohesion (Fischer and Qaim, 2014).

\subsubsection{Models with interaction effects}

To explain possible sources of preference heterogeneity, we added interaction terms as additional covariates, as was explained above. Results of these extended model estimates are shown in models (2) and (3) of Table 2.5. We concentrate the discussion on the coefficients of the interaction terms. In model (2), ASC is interacted with actual insurance uptake in the past. The insignificant coefficients for the interactions with WII uptake in 2013 and 2014 suggest that recent adopters and non-adopters of insurance contracts have similar preferences. However, the interaction with WII uptake before 2013 is positive and significant, meaning that earlier adopters who then dropped out have less positive attitudes towards insurance contracts. This is plausible, as their decision to drop out from the existing WII program was probably related to not being fully satisfied.

The results in model (3) confirm that levels of satisfaction with the existing insurance program determine farmer attitudes: higher levels of satisfaction contribute to a higher general preference for WII. Somewhat surprising is the negative coefficient for the ASC interaction with risk attitudes, which implies that risk-loving farmers have more positive attitudes towards WII. One would usually expect the opposite, namely that risk-averse farmers have a stronger preference for crop insurance. We interpret this result as another sign that not all farmers are yet fully confident with the functioning of WII contracts. Given the lack of transparency regarding rainfall measurements and pay-out triggers, risk-averse farmers may not feel properly insured against weather shocks. Some may even consider WII as a kind of gamble on 
random weather outcomes. This is consistent with previous studies showing that risk-averse farmers are often less likely to adopt WII (Giné et al., 2008; Hill et al., 2013; Clarke, 2016).

Limited confidence may also be related to the complexity of WII, especially for smallholder farmers who are often unfamiliar with formal insurance products (Patt et al., 2010). The other interaction terms in model (3) confirm the important role of training and learning. Farmers who received training as part of the Kilimo Salama Program have more positive attitudes towards WII. Furthermore, membership in a farmer group, which can serve as a learning platform for innovations, affects attitudes towards WII in a positive way.

Finally, we were interested in the role of farm size. To analyze possible heterogeneity between smaller and larger farms, we created a dummy variable that takes a value one if a particular farm is above the mean farm size in the sample. The positive and significant coefficient for the interaction of this dummy with ASC reveals that smaller farms have a higher preference for WII. This is a welcome finding, as it demonstrates the potential of properly-designed WII products to benefit smallholder farmers. This potential is not yet fully realized.

\subsubsection{Willingness to pay (WTP)}

Based on the estimates in model (1), we calculated farmers' WTP for WII contracts and for changes in particular contract attributes. We used individual-specific coefficients to obtain WTP point estimates for the farmers in our sample (Hensher et al., 2005). Results are presented in Table 2.6. We only show results for attribute levels with significant coefficient estimates. For the ASC, we multiplied the coefficient estimates by -1 , because we are interested in the WTP for insurance, not for the no-insurance option. On average, farmers are willing to pay about $7.6 \%$ of their expected harvest for a WII contract. As mentioned, the actual price varies by location, but the average premium rate in the Kilimo Salama Program is $10 \%$. Moderate premium reductions could probably increase insurance uptake significantly. The mean estimate also suggests that contracts priced at 20 or $25 \%$, as observed in some locations, are way above what the average farmer is willing and able to pay for WII. 
Table 2.6: Marginal willingness to pay for WII attributes

\begin{tabular}{lcccc}
\hline Variables & Mean (\%) & Std. deviation & Lower CI & Upper CI \\
\hline ASC & 7.56 & 1.90 & 7.37 & 7.75 \\
Transparency & 0.79 & 0.34 & 0.76 & 0.83 \\
Strike level $-40 \%$ & -0.41 & 0.09 & -0.42 & -0.40 \\
$\pm 20 \%$ & 0.16 & 0.03 & 0.16 & 0.17 \\
$\pm 40 \%$ & 0.18 & 0.03 & 0.18 & 0.19 \\
Large group contract & -0.31 & 0.66 & -0.38 & -0.24 \\
Small group contract & 0.23 & 0.46 & 0.19 & 0.28 \\
Distance (50 km) & -0.24 & 0.20 & -0.26 & -0.22 \\
\hline
\end{tabular}

Notes: Confidence intervals (CI) refer to the $95 \%$ level. Willingness to pay (WTP) was calculated by dividing individual-specific coefficients for attribute level by the premium rate coefficient. For the ASC, the coefficient was multiplied by -1 to obtain the WTP for insurance in general. WTP is only shown for attribute levels with significant coefficient estimates in model (1) of Table 2.5.

The WTP estimates for the different attribute levels can be interpreted as increments over the base value of insurance. That is, the mean WTP for a contract with transparent communication of weather data through weekly text messages would be $7.56+0.79=8.35 \%$ of the expected harvest. The point estimates for the different attribute levels are all highly significant but quite small in magnitude, which may be due to the assumed lognormal distribution of the premium rate variable. However, even if the marginal WTP for the attribute levels was underestimated, relative comparisons should still be in order because the same calculation methods were used for all attributes. The highest marginal WTP is observed for the transparency attribute. Transparency also seems to be more important than distance to the weather station. Even though farmers are willing to pay less for contracts with reference stations further away from their farm, the WTP comparison suggests that transparent communication and information provision may have a larger effect on insurance uptake than investing in additional weather stations to reduce basis risk.

Concerning the other attributes, farmers are willing to pay 0.41 percentage points less for contracts that only start paying at a rainfall threshold level of $-40 \%$. For contracts that are also covering excess rainfall, farmers are willing to pay more, but the additional WTP is relatively small. Comparing values across attributes we learn that - at least for this study area - focusing on drought risk with a lower absolute strike level is more valuable for farmers than covering additional risks, as the existing Kilimo Salama Program does. Finally, the estimates show that large-group contracts would only be chosen over 
individual contracts if the premium was 0.31 percentage points lower, whereas small-group contracts would result in a 0.23 percentage point higher WTP.

\subsection{Conclusions}

Weather index insurance (WII) could reduce the high transaction costs involved in traditional, indemnity-based crop insurance programs and could therefore be of particular relevance for smallholder farmers in developing countries. However, the uptake of WII in the small-farm sector has been relatively low up till now. One reason is probably that WII contracts are not sufficiently tailored to the needs and preferences of smallholder farmers. Improved contractual design might help towards more widespread insurance uptake. In this study, we have contributed to the knowledge base focusing on the situation of smallholder farmers in Kenya. We have combined farm survey and choice-experimental data to analyze the experience with an existing WII program and to better understand how hypothetical changes in the insurance contracts might improve the situation.

While the existing WII program in Kenya was launched in 2009, the number of participating farmers has remained relatively low. Several farmers also decided to discontinue their insurance contracts after one or two years of participation. One issue is that the insurance contracts are too expensive from the farmers' point of view. Our analysis has shown that farmers' mean willingness to pay is about $25 \%$ lower than the average premium rate charged by the insurance provider. Lower premium rates could probably contribute to increased insurance uptake.

Beyond the premium rate we identified several other contract attributes that seem to be critical. Many farmers struggle with fully understanding the functioning of WII contracts and when exactly payouts are triggered. The resulting uncertainty undermines farmers' confidence and thus lowers their demand for insurance. Risk-averse farmers in particular were found to have a low preference for WII contracts, even though they are actually the main target group of insurance products. Our estimates suggest that better training and communication could increase farmers' confidence and thus insurance uptake. 
Transparent provision of relevant rainfall measurements and thresholds - for instance through regular text messages - could significantly increase farmers' willingness to pay for WII. Mechanisms to reduce basis risk are also valued by farmers, although not to the same extent as higher levels of transparency. Improving communication may therefore be more important for WII providers than investing into additional weather stations in order to reduce basis risk. Offering contracts to farmer groups rather than individuals was also found to be a promising avenue for wider insurance uptake. Group contracts could help to reduce transaction costs. Furthermore, farmer groups can be important platforms for learning about complex innovations, including novel risk transfer products. For this, however, group sizes should be relatively small, as larger groups often lack the necessary cohesion.

We caution that the results are specific to Kenya and that choice experimental data may be subject to hypothetical bias. Hence, the exact estimates should not be generalized and over-interpreted. However, the findings still provide interesting insights into typical issues of WII design in a small-farm context. Given that smallholder farmers are particularly vulnerable to climate shocks, improving their access to crop insurance is of high policy relevance. More research is needed to further add to the knowledge base about suitable contractual designs in particular situations. 


\title{
Chapter 3: Effects of Weather Index Insurance on Input Use and Productivity in Kenya
}

\begin{abstract}
Weather risk is a serious issue affecting the usage of fertilizer and other external inputs by smallholder farmers. However, without moderately increasing the intensity of these external inputs it will be difficult to achieve rapid productivity growth and food security particularly in sub-Saharan Africa. This paper contributes to the emerging literature on the factors influencing weather index insurance (WII) adoption and its effects on input use and crop productivity. Unlike previous studies which build on randomized field experiments, we use observational data from a survey of smallholder farmers in Kenya, who had participated in a commercial WII scheme. After controlling for selectivity bias and other factors, the empirical results reveal positive and significant effects of WII uptake on the intensity of fertilizer and improved seeds. Insurance uptake is also associated with a significant improvement in maize productivity, which mainly comes through the increase in fertilizer application. The results underscore the need for upscaling WII programs to increase their coverage. At the moment only a small proportion of farmers participate in existing programs, which limits the potential gains in agricultural productivity development that can be achieved from insurance provision.
\end{abstract}

Key words: Weather risk, fertilizer, maize productivity, crop insurance, endogenous treatment regression, Africa 


\subsection{Introduction}

Agricultural productivity growth remains the effective vehicle for poverty reduction and food security in rural areas of developing countries (World Bank, 2008). Yet increasing threats of climate change, declining resources for production, and a steadily growing human population have raised the need for agricultural intensification (Reardon et al., 1999; Burney et al., 2010; Jayne et al., 2014). Specifically for sub-Saharan Africa (SSA) it is recognized that intensifying smallholder agriculture, through increasing fertilizer use and adoption of improved seed varieties is one approach that can effectively reduce food insecurity and rural poverty (Minten and Barrett, 2008; Otsuka and Larson, 2013; Shiferaw et al., 2014).

To this end, remarkable policy initiative is visible in terms of input market reforms in some countries, and targeted fertilizer subsidies in others (Jayne et al., 2003; Mason et al., 2016). However, adoption rates for fertilizer and modern seed technologies in SSA remain generally low compared to the rest of the developing world (Evenson and Gollin, 2003; Morris et al., 2007). Furthermore, government intervention through input subsidies is widely contested; critics arguing that such programs are tainted by inefficiencies in implementation. They are also seen to take substantial chunks of national agriculture budgets, which would be better utilized to provide public infrastructure that lower transaction costs in input markets (Kelly et al., 2003; Jayne and Rashid, 2013).

An emerging literature is keen on the role of risk and looks at whether provision of weather index insurance (WII) might induce demand for purchased inputs as an alternative to market distorting input subsidies (Farrin and Murray, 2014). Indeed weather risk is a serious impediment in rain-fed agriculture. Variability in rainfall and temperatures not only affects crop productivity directly, it also discourages farmers from investing in productive inputs when the outcome becomes too uncertain (Alem et al., 2010).

In an effort to provide agricultural insurance solutions, a number of index insurance programs have recently been initiated in developing countries (IFAD, 2010). With provision of insurance usually the expectation is that risk averse farmers will be more willing to switch to modern technologies, which are riskier but high-yielding, hence boosting their productivity (Carter et al., 2016). Availability of formal 
insurance might also improve farmers' access and demand for agricultural credit which lowers liquidity constraints in input adoption (Boucher et al., 2008; Farrin and Miranda, 2015).

Despite these valid expectations, WII products have equally been met with low demand (Binswanger-Mkhize, 2012; Cole et al., 2013). In addition, empirical studies analyzing the impact of WII on production decisions are scarce, probably because most of the programs were still in their infancy. There are a few exceptions, such as Giné and Yang (2009) who surprisingly found a negative influence of WII on loan uptake for technology adoption in Malawi. Yet similar studies using field experiments have reported positive effects of WII on crop acreage and farm investments among smallholder farmers in Ghana, Ethiopia, and Mali (e.g., Karlan et al., 2014; Berhane et al., 2015; Elabed and Carter, 2015). Amidst this mixed evidence it remains unclear if WII is really an appropriate tool to foster input use and productivity growth in small-farm contexts. Furthermore, it is useful to find out if findings from previous studies can be observed in other areas; especially beyond the pilot experiments as WII projects upscale into commercial schemes.

Concerning crop insurance in general, some articles have analyzed input use effects in the context of indemnity-based insurance schemes (Horowitz and Lichtenberg, 1993; Mishra et al., 2005, among others). An indemnity-based insurance differs from an index insurance contract since in the latter; payouts are not based on actual damage to the crop, rather they are based on an objectively measured variable (e.g., average rainfall) that serves as a proxy for farm losses. As such, provision of index insurance contracts leads to different input use incentives because moral hazard and adverse selection are not serious problems as they would be in damage-based insurance schemes (Barnett and Mahul, 2007).

This paper thus adds to the available knowledge by analyzing determinants of WII adoption and its effects on input use and productivity using the example of maize, which is a staple food crop. Unlike previous studies which relied on randomized field experiments, here we build on survey data of insured and non-insured farmers in Kenya. Insured farmers were those who had purchased rainfall index insurance through a program known as Kilimo Salama. The program was first initiated in Kenya in 2009. It is a unique example of a commercially marketed index insurance scheme in SSA; that offers a range of 
agricultural insurance products tailored for the needs of smallholder farmers (Greatrex et al., 2015). For empirical analysis, we use an endogenous treatment-effects regression model that accounts for potential observed and unobserved differences between insured and non-insured farmers that could also be correlated with crop productivity. Failure to account for these differences would result in biased estimates of index insurance effects, since there are farmers who use higher levels of fertilizers or achieve relatively higher yields, for example, whether or not they purchase insurance.

The rest of this paper proceeds as follows. In the next section we explain the analytical procedure used in the paper. Then we give a brief description of the study context, the survey process and data. After that we present results and discussions before summarizing the main conclusions at the end.

\subsection{Analytical framework}

In general, provision of formal risk management instruments to farmers is likely to influence farm performance through a number of pathways, stemming from the multiple effects of risk on agricultural systems. Apart from influencing input use decisions, provision of insurance where it was technically missing before could cause shifts in crop acreages, by encouraging resource endowed farmers to expand the cultivated land (Goodwin et al., 2004). Insurance provision could also alter cropping patterns, as farmers may feel confident to specialize or shift to crops directly covered by the insurance program (Wu, 1999; Karlan et al., 2014). Since WII has a low incentive for moral hazardous tendencies, one would expect insurance holders to portray higher overall productivity levels. Our analysis concentrates on effects (if any) that arise from differences in input use between insured and non-insured farmers.

Risk is expected to play a greater role on the intensity of using purchased inputs because they entail a cash investment. We conceptualize that the farmer faces a sequence of decisions, namely whether to take-up a WII cover, and subsequently the quantity of external inputs to use. To model WII adoption, suppose that the level of WII coverage desired by farmer $i$ (for $i=1,2, \ldots, N$ ) is denoted as $C_{i}^{*}$. Also suppose that $C_{i}^{*}$ is a latent variable coded as a dichotomous choice equal to one if farmer $i$ buys a WII contract and zero if otherwise. The reduced-form adoption equation can be expressed as 


$$
\begin{aligned}
& C_{i}^{*}=\alpha^{\prime} Z_{i}+u_{i}, \\
& \text { with } C_{i}=1 \text {, if } C_{i}^{*}>0 \text { and } C_{i}=0 \text { otherwise }
\end{aligned}
$$

where $Z_{i}$ is a vector of explanatory variables and $u_{i}$ is a random error term. Equation [3.1] is estimated separately using a probit model, including explanatory variables related to risk attitudes, coping strategies, access to insurance information, wealth, and group membership among other socio-economic factors that could affect the probability of purchasing WII. Further we are interested in analyzing the potential effects of WII adoption on input use and crop productivity outcomes $\left(Y_{i}\right)$,

$$
Y_{i}=\beta^{\prime} X_{i}+\delta C_{i}+\varepsilon_{i}
$$

where $X_{i}$ is a vector of covariates, $C_{i}$ is a dummy for WII purchase, $\varepsilon_{i}$ is a random error term, and $\delta$ measures the treatment effect. If at all uptake of WII was random, then simply estimating equation [3.2] by ordinary least squares would provide an unbiased estimate of intended WII effects $(\delta)$. However, WII adoption is not random. It might be subject to selectivity bias (Heckman, 1979). For example individuals who choose to take-up insurance could as well be the more "enterprising” ones who ordinarily use more external inputs. They could also be the more productive farmers, who would achieve higher output whether or not they bought insurance. As such, unobservable factors affecting WII uptake $\left(u_{i}\right)$ may be correlated with those affecting production outcomes $\left(\varepsilon_{i}\right)$. We require a modeling strategy that eliminates such a bias.

\subsubsection{Addressing selection bias}

While there are a couple of approaches for managing selection bias in a causal-effect study such as through propensity score matching (Rosenbaum and Rubin, 1983) and instrumental variable (IV) approaches (Angrist et al., 1996); each method has its own practical challenges. For instance, the matching approach only uses observed characteristics to compare participants to a matched group of nonparticipants. However, many factors that simultaneously influence WII uptake and input use or 
productivity are unobservable. On the other hand, to use IV approaches one requires valid instruments. We were able to find a suitable instrument therefore we apply the IV method: first of all by using an endogenous treatment regression model. The model assumes a joint normal distribution between error terms, and it estimates the treatment and outcome equations simultaneously; hence correcting for possible endogeneity and selection bias (Greene, 2012, p. 931).

Second, to facilitate the identification of treatment effects we use an instrument for insurance uptake, which is "whether a farmer received training on WII". For an instrument to be valid it needs to be exogenous itself, and it should be correlated with the treatment, but not the outcomes. Our selected instrument seems appropriate because it significantly influences WII uptake, but has no direct influence on the production outcomes of interest, except through the indirect effect of insurance uptake (Angrist et al., 1996; Kabunga et al., 2014). To be sure, we performed pair-wise correlations between the instrument and all production variables first using the full sample (Table A1 in appendix). The same test was repeated only among non-participants similar to Di Falco et al. (2011) and results are shown in Table A2. Thus, we confirmed that the selected instrument was not directly correlated with the outcomes.

In addition regarding trainings, the insurance program has employed field officers who train farmers about available index insurance products. The trainers often meet people in public gatherings which make training less endogenous on the farmers' choice. There are factors that might limit the ability to attend public meetings in general for example due to old age, or distance. To control for this weakness we have included human capital and market distance variables in our models, since most gatherings are held at local market centers. Another advantage is that insurance agents are independent from agricultural extension providers and usually operate over a wide region; hence we have no reason to believe index insurance trainings would be directly correlated with farm productivity.

\subsubsection{The treatment regression model}

To explain briefly how the endogenous treatment regressions are specified, we show the selection [3.3] and outcome [3.4] equations as follows, 


$$
\begin{aligned}
& C_{i}=\alpha_{0}+\alpha_{1} T_{i}+\alpha_{2} X_{i}+u_{i} \\
& Y_{i}=\beta_{0}+\beta_{1} X_{1 i}+\beta_{2} X_{2 i}, \ldots,+\beta_{k} X_{k i}+\delta C_{i}+\varepsilon_{i}
\end{aligned}
$$

where $T_{i}$ is the instrument for WII uptake, and the other variables are as defined above. For ease of identification all explanatory variables in the outcome equations are also included in the selection equation in addition to the instrument. The input regressions include (logged) input levels as dependent variables against a set of right-hand-side variables expected to affect the extent of using purchased inputs. Explanatory variables capture aspects like land- and labor-endowment, capital, information and market access, as well as risk attitudes and other farmer and farm characteristics. Log transformation of the input variables is useful in this case because the data is highly skewed. Figures A.1 - A.4 (in the appendix) illustrate that data for fertilizer and maize seed were originally positively skewed, but by log transforming the two variables we achieve a relatively normal distribution. To ensure that zero observations remain included in the log-transformed variables, we add “one” before taking the natural logarithm.

In the crop yield regression we use a Cobb-Douglas specification, and include dummy variables for inputs that are not used by all farmers as suggested by Battese (1997). Other control variables related to farm management ability, risk, information access, and locational characteristics are also added to the yield regression. Since WII is expected to affect productivity mainly through inputs, we include production inputs to the regression in a step-wise manner, as we observe the respective changes in the WII coefficient so as to interpret crop productivity effects.

The advantage with the treatment regression model is that the two error terms $\left(u_{i}, \varepsilon_{i}\right)$ are assumed to be jointly normally distributed with a mean of zero and a covariance matrix equal to

$$
\left[\begin{array}{cc}
\sigma^{2} & \rho \sigma \\
\rho \sigma & 1
\end{array}\right]
$$

This means correlation (denoted $\rho$ ) between the error terms is accounted for within the model, solving the endogeneity problem in insurance adoption. We estimate equations [3.3] and [3.4] simultaneously using the full information maximum likelihood estimator in STATA. This approach is not only consistent but also computationally efficient, and results in unbiased parameter estimates (Greene, 2012, p. 931). 


\subsection{Background, farm survey, and data}

\subsubsection{Study area and WII program in Kenya}

The empirical data used in this study was collected in 2014 as part of a broader household survey on weather index-based crop insurance in Embu County, Kenya. Kenya was an interesting context because index insurance initiatives for both crops and livestock have been implemented in the country since 2009 (FSD, 2013; Jensen et al., 2016). The most successful of these initiatives is the so called Kilimo Salama program of the Syngenta Foundation for Sustainable Agriculture (IFC, 2015). The program offers rainfall index insurance contracts against the risks of drought and excess rain. In particular input insurance is provided through arrangements with input dealers. Farmers choose whether to purchase insured inputs - i.e., paying insurance premiums as part of the input cost - or inputs from other companies that are not part of the insurance arrangement. For example, certified maize seed (from Kenya Seed Company), fertilizer (from MEA, an input company) and chemicals inputs (from Syngenta) have been included in the input insurance arrangement.

The local input dealer can register insured farmers on behalf of the insurer. In other cases the input package already contains a unique code inside. Farmers register themselves by sending a text message to the insurer stating the unique code. This is done at the farm just before planting so that the location of the farm can be detected and also to mark the start of the contract. Rainfall is monitored for the first 21 days of planting; if within this period rainfall fails then a pay-out is triggered and sent to farmers automatically through mobile money networks. Thus, Kilimo Salama's input insurance plan offers a great motivation for higher input use because farmers can recover the full cost of their insured inputs, without waiting until the end of the season, which allows drought affected farmers to replant (Greatrex et al., 2015). We sort to investigate the factors that influence input demand in this context, and the implications of the insurance program so far on input use and crop productivity.

Specifically, we chose Embu County for this research because it was one of the areas where WII interventions were first piloted in Kenya (Sina and Jacobi, 2012). At the time of the survey, WII initiatives had been implemented in the County for more than five years, which offered a good setting for evaluating 
causal impacts. Moreover within Kenya, Embu is located in the Eastern region where erratic and insufficient rainfall is a serious concern for agricultural production (Ngetich et al., 2014).

\subsubsection{Survey and data}

The households to be surveyed were selected using a multi-stage stratified sampling procedure. First, we purposively selected Embu-East sub-county, which had a relatively higher number of farmers insured through Kilimo Salama. Embu-East has two administrative divisions (Kyeni and Runyenjes); within each division we randomly selected three sub-locations (smallest administrative units). Then in each of the six sub-locations, we interviewed all farmers that were at that time insured or who had purchased an index insurance contract in previous years. These farmers were identified through lists provided by Kilimo Salama field staff. Overall, we interviewed 152 "ever-insured” farmers. In addition, 234 non-insured farmers were randomly selected in the same six sub-locations, resulting in a total sample size of 386. Although insured farmers were deliberately over-sampled, the two sub-samples are representative for "ever-insured” and non-insured farmers in Embu-East.

Primary data was collected through face-to-face interviews with the key decision maker in each household. The data collection was administered with the help of a small team of local enumerators, essentially students from Egerton University, whom we hired and trained specifically for this research. The survey questionnaire was carefully designed and pretested before the main survey. It captured information on farm production, weather shocks, risk preferences, and actual experiences with WII; as well as other socio-economic data at household level. Summaries of these household and production characteristics of relevance for this paper are provided in Tables 3.1 and 3.2.

The data was collected with reference to 2013 cropping year, therefore we use insurance uptake in 2013 as our treatment variable. About 23\% of all farmers in our sample purchased a WII contract in 2013. This should not be interpreted as the rate of adoption in the overall population. Among all farmers in Embu-East insurance uptake in general did not exceed 10\%. Table 3.1 shows the overall sample means as well as comparisons between "insured" farmers and the rest. Farmers in the sample are typical 
smallholders owning an average of 2.2 acres of land. Insured farmers own more land, and engage more in farming with fewer opportunities for off-farm work. Apart from diversifying off-farm, the average farmer grows an average of three crops and invests in livestock. These diversification strategies are useful in coping with production risks. For instance droughts are a major problem in the area. According to farmers' recall, severe rainfall failure occurred on average 2.5 times over a five year span. However, we do not observe significant differences in risk exposure and risk attitudes between insured and non-insured farmers. Further comparisons indicate that fewer male headed households purchase WII. Insured farmers are also older and probably more experienced in farming; they are likely to be farmers with ease of transportation; and generally more networked and better informed about index insurance than their noninsured counterparts.

\subsubsection{Maize production characteristics}

Table 3.2 provides summary statistics for maize output and inputs that will be used later on for impact assessment. Maize is an important food crop in East and Southern Africa. The average maize yield in our sample is about one metric ton with fertilizer use, which is comparable to the 1.3 tons reported by Ariga et al. (2008) from a country-wide panel study. Fertilizer use on maize is relatively high (68 kg/acre) than what is usually observed in the African context. Actually, almost all sample farms apply fertilizer on their maize crop. Nonetheless, our mean is not very different from the Kenyan national average of about $60 \mathrm{~kg} / \mathrm{acre}$, which varies between $75 \mathrm{~kg} /$ acre in high potential maize producing areas to as low as seven kg/acre in the drier lowland areas (Ariga et al., 2008). Still, the Kenyan Ministry of Agriculture encourages higher fertilizer application (100 kg/acre) through the National Accelerated Input Access Program (Mason et al., 2016). To improve soil fertility, animal manure could be used in supplementing inorganic fertilizer. However, close to $50 \%$ of the farmers in our sample did not apply manure. Furthermore, insured farmers applied significantly less manure on maize than the other farmers. Insured farmers also cultivated larger maize area. Other than these two variables, we do not find any statistically significant differences in input use or crop productivity based on WII uptake. Since these are only 
descriptive results, we cannot draw conclusions or really attribute the differences to insurance adoption. In what follows we discuss results of the econometric analysis.

\section{Table 3.1: Descriptive statistics of the sample}

\begin{tabular}{|c|c|c|c|c|c|c|}
\hline \multirow{3}{*}{$\begin{array}{l}\text { Variables } \\
\text { Household and farm characteristics }\end{array}$} & \multicolumn{6}{|c|}{ Means (SD) } \\
\hline & \multicolumn{2}{|c|}{ All $(n=386)$} & \multicolumn{2}{|c|}{ Insured, $2013(\mathrm{n}=87)$} & \multicolumn{2}{|c|}{ Non-insured $(n=299)$} \\
\hline & & & & & & \\
\hline Total land owned (acres) & 2.20 & $(2.47)$ & $3.08^{* * *}$ & $(3.44)$ & 1.95 & $(2.05)$ \\
\hline Cultivated area (acres) & 2.09 & $(1.92)$ & $2.71 * * *$ & $(2.73)$ & 1.91 & $(1.57)$ \\
\hline Total annual income ('000 Ksh) & 192.92 & (368.99) & 185.04 & $(244.61)$ & 195.22 & $(398.26)$ \\
\hline Share of off-farm income (\%) & 32.79 & $(32.70)$ & $26.01^{* *}$ & $(30.96)$ & 34.76 & (32.98) \\
\hline Off-farm occupation (dummy) & 33.42 & $(47.23)$ & 29.89 & $(46.04)$ & 34.45 & $(47.60)$ \\
\hline Crop diversification (crop count) & 2.80 & $(1.06)$ & 2.74 & $(1.17)$ & 2.82 & $(1.03)$ \\
\hline Value of livestock owned ('000 Ksh) & 63.01 & $(116.90)$ & 65.43 & (53.63) & 62.31 & (129.70) \\
\hline Frequency of droughts (past 5 years) & 2.52 & $(1.54)$ & 2.62 & $(1.50)$ & 2.49 & $(1.55)$ \\
\hline Own irrigation equipment (dummy) & 7.51 & (26.39) & 9.20 & $(29.06)$ & 7.02 & $(25.60)$ \\
\hline Risk averse (\% with WTR between 0-4 ) & 19.95 & $(40.01)$ & 21.84 & $(41.55)$ & 19.40 & (39.61) \\
\hline Risk neutral (\% with WTR between 5-6) & 22.54 & $(41.84)$ & 18.39 & (38.97) & 23.75 & $(42.62)$ \\
\hline Risk loving (\% with WTR between 7-10) & 57.51 & $(49.50)$ & 59.77 & $(49.32)$ & 56.86 & $(49.61)$ \\
\hline Male household head (dummy) & 67.88 & $(46.76)$ & $59.77 *$ & $(49.32)$ & 70.23 & $(45.80)$ \\
\hline Age of farmer (years) & 52.11 & $(14.56)$ & $55.73 * * *$ & $(12.94)$ & 51.06 & (14.85) \\
\hline Education of farmer (years) & 8.18 & $(4.01)$ & 8.05 & $(4.48)$ & 8.22 & $(3.87)$ \\
\hline Male labor endowment (adult males/area) & 1.03 & $(1.35)$ & $0.80 *$ & $(0.77)$ & 1.10 & $(1.47)$ \\
\hline Female labor endowment (adult females/area) & 1.09 & $(1.19)$ & $0.76^{* * *}$ & $(0.83)$ & 1.19 & $(1.26)$ \\
\hline Own transportation means (dummy) & 59.33 & (49.19) & $68.97 * *$ & (46.53) & 56.52 & (49.66) \\
\hline \multicolumn{7}{|l|}{ Institutional characteristics } \\
\hline Group membership (dummy) & 88.08 & (32.44) & $93.10^{*}$ & (25.49) & 86.62 & $(34.10)$ \\
\hline Access to credit (dummy) & 38.60 & $(48.75)$ & 40.23 & $(49.32)$ & 38.13 & $(48.65)$ \\
\hline Agric. extension in 2013 (contacts) & 1.51 & $(3.54)$ & 1.26 & $(1.69)$ & 1.60 & (3.99) \\
\hline Time taken to input market (minutes) & 32.51 & $(25.30)$ & 30.48 & $(24.14)$ & 33.11 & $(25.64)$ \\
\hline Fertilizer price (Ksh/kg) & 65.53 & $(4.65)$ & 65.33 & $(2.88)$ & 65.59 & $(5.05)$ \\
\hline \multicolumn{7}{|l|}{ WII-related characteristics } \\
\hline Purchased WII before 2013 (dummy) & 28.24 & $(45.07)$ & $67.82 * * *$ & (46.99) & 16.72 & (37.38) \\
\hline Received WII training in 2013 (dummy) & 41.19 & $(49.28)$ & $66.67 * * *$ & $(47.41)$ & 33.78 & (47.38) \\
\hline $\begin{array}{l}\text { Knows location of weather station(s) } \\
\text { (dummy) }\end{array}$ & 53.37 & $(49.95)$ & $77.01^{* * *}$ & $(42.32)$ & 46.49 & $(49.96)$ \\
\hline
\end{tabular}


Table 3.2: Maize production: Descriptive analysis

\begin{tabular}{lcccccc}
\hline & \multicolumn{7}{c}{ Means (SD) } \\
\cline { 2 - 7 } Variables & \multicolumn{7}{c}{ All maize farmers (n=382) } & Insured, 2013 (n=86) & Non-insured (n=296) \\
\hline Revenue in 2013 ('000 Ksh/acre) & 31.75 & $(27.74)$ & 30.44 & $(24.93)$ & 32.13 & $(28.53)$ \\
Yield (kg/acre) & 1119.78 & $(905.64)$ & 1118.65 & $(841.71)$ & 1120.11 & $(924.74)$ \\
Seed expense ('000 Ksh/acre) & 3.07 & $(2.43)$ & 3.03 & $(2.18)$ & 3.08 & $(2.50)$ \\
Inorganic fertilizer (kg/acre) & 67.91 & $(57.64)$ & 63.32 & $(45.37)$ & 69.25 & $(60.74)$ \\
Used fertilizer (dummy) & 97.64 & $(15.19)$ & 97.67 & $(15.16)$ & 97.64 & $(15.22)$ \\
Pesticide ('000 Ksh/acre) & 0.75 & $(1.20)$ & 0.76 & $(1.09)$ & 0.75 & $(1.23)$ \\
Used chemical pesticides (dummy) & 69.11 & $(46.26)$ & 72.09 & $(45.12)$ & 68.24 & $(46.63)$ \\
Manure (MT/acre) & 4.99 & $(18.29)$ & $3.46 *$ & $(4.73)$ & 5.44 & $(20.61)$ \\
Used animal manure (dummy) & 56.02 & $(49.70)$ & 56.98 & $(49.80)$ & 55.74 & $(49.75)$ \\
Labor (man-days/acre) & 82.12 & $(64.06)$ & 75.25 & $(55.51)$ & 84.11 & $(66.30)$ \\
Maize area (acres) & 1.01 & $(0.92)$ & $1.32 * * *$ & $(1.35)$ & 0.91 & $(0.72)$ \\
\hline
\end{tabular}

Note: $* * *$ and $*$ indicate mean difference is statistically significant at $1 \%, 5 \%$, and $10 \%$ levels respectively.

\subsection{Results and discussion}

\subsubsection{The WII uptake decision}

Before analyzing the causal impacts, it is important to have a better understanding of the factors influencing weather index insurance purchase. Table 3.3 presents results of the probit model estimation for this purpose. As mentioned, the dependent variable is binary, coded as one if a WII contract was purchased in 2013, and zero otherwise. Overall the model Chi-squared statistic was significant with McFadden's Pseudo R-squared greater than 0.2 as shown at the bottom of the table. Estimation results show that being trained on WII, knowing where the reference weather station is located, and actual previous experience with the insurance significantly improve the probability of purchasing a WII contract. This indicates that knowledge of insurance is low, and that capacity building could be important in upscaling the coverage of WII programs (Takahashi et al., 2016). There is perhaps progressive learning of the insurance over time, in that those who previously took-up an insurance contract are more likely to participate in subsequent years. Knowing the physical location of the reference weather stations also demystifies the insurance and increases farmer trust in the insurance program, which leads to the positive effect on adoption. 
Table 3.3: Probit model results: WII uptake decision

\begin{tabular}{|c|c|c|c|c|}
\hline Variables & Coefficients & & $d y / d x$ & \\
\hline Received WII training (dummy) & $0.798 * * *$ & $(0.182)$ & $0.158 * * *$ & $(0.034)$ \\
\hline Knows location of weather station(s) (dummy) & $0.558 * * *$ & $(0.208)$ & $0.110^{* * *}$ & $(0.040)$ \\
\hline Purchased WII before 2013 (dummy) & $1.233 * * *$ & $(0.203)$ & $0.244 * * *$ & $(0.034)$ \\
\hline Male household head (dummy) & -0.215 & $(0.195)$ & -0.042 & $(0.038)$ \\
\hline Age of farmer (years) & $0.015^{* *}$ & $(0.007)$ & $0.003 * *$ & $(0.001)$ \\
\hline Education of farmer (years) & 0.016 & $(0.026)$ & 0.003 & $(0.005)$ \\
\hline Risk neutral $(5 \leq \text { WTR } \leq 6)^{a}$ & $-0.586 * *$ & $(0.278)$ & $-0.116^{* *}$ & $(0.054)$ \\
\hline Risk loving ( $\leq$ WTR $\leq 10)$ & -0.256 & $(0.222)$ & -0.051 & $(0.044)$ \\
\hline Total land owned (acres) & $0.054 *$ & $(0.030)$ & $0.011^{*}$ & $(0.006)$ \\
\hline Frequency of drought (past 5 years) & -0.035 & $(0.057)$ & -0.007 & $(0.011)$ \\
\hline Share of off-farm income (\%) & $-0.540 *$ & $(0.285)$ & $-0.107^{*}$ & $(0.057)$ \\
\hline Crop diversification (crop count) & -0.081 & $(0.096)$ & -0.016 & $(0.019)$ \\
\hline Agricultural extension in 2013 (contacts) & $-0.090 *$ & $(0.050)$ & $-0.018 *$ & $(0.010)$ \\
\hline Group membership (dummy) & $0.525 * *$ & $(0.257)$ & $0.104 * *$ & $(0.051)$ \\
\hline Credit access (dummy) & -0.113 & $(0.196)$ & -0.022 & $(0.039)$ \\
\hline Own transportation means (dummy) & $0.335^{*}$ & $(0.194)$ & $0.066^{*}$ & $(0.038)$ \\
\hline Constant & $-2.714 * * *$ & $(0.603)$ & & \\
\hline Location dummies included & [Yes] & & & \\
\hline Log likelihood & -137.784 & & & \\
\hline Chi-squared & $114.09 * * *$ & & & \\
\hline Pseudo $\mathrm{R}^{2}$ & 0.331 & & & \\
\hline
\end{tabular}

Notes: Number of observations is 386. Shown are coefficients, marginal effects and robust standard errors in parenthesis. ${ }^{* * *},{ }^{* *}$, and $*$ indicate statistical significance at $1 \%, 5 \%$, and $10 \%$ levels, respectively.

${ }^{a}$ WTR is a willingness-to-take risk score. Reference is risk averse $[1 \leq \mathrm{WTR} \leq 4]$.

Furthermore, age of the farmer has a positive influence on WII uptake. Specifically, a one year increase in farmer's age raises the probability of purchasing WII by 0.3 percentage points, indicating that older and experienced farmers are likely to attach a higher value on risk management instruments (Sherrick et al., 2004). To capture the role of risk attitudes we inquired on farmers' willingness to take risks (WTR) in farming, based on a score of $1=$ "completely risk averse” to $10=$ "completely risk loving” similar to Dohmen et al. (2011). Results show that highly risk averse farmers have a generally higher likelihood of insuring than the risk neutral or risk lovers, which is consistent with theoretical expectations. However, this finding contradicts some previous studies which found a negative relationship between risk aversion and WII demand (e.g., Giné et al., 2008; Hill et al., 2013). We attribute the difference to the fact 
that the WII program in Kenya had been in existence for some years, which means uncertainty about the insurance may have been lower in our case. Also different from what is often found in ex ante studies; here we observe that, in terms of the actual purchase, it is those who are risk averse who would most likely adopt index insurance.

Land is an important resource for production and an indicator of wealth. We observe that insurance uptake increases with the size of land owned. This finding might appear counterintuitive, given that micro-insurance schemes are aimed at including smaller farmers. However, we could argue that larger acreage offers room for expanding the cultivated area. Land availability also reflects economies of scale and potential for commercialization. Hence the attractiveness of insurance among land endowed households may be due to the need to reduce economic risk (Sherrick et al., 2004).

The coefficient for share of off-farm income is negative. The marginal effect (11 percentage points) is also relatively large implying that farmers with capacity to self-insure through off-farm income diversification are less likely to purchase WII. Quite unexpected though, is the negative influence of agricultural extension trainings on insurance purchase. Ideally agricultural extension is not supposed to create disincentives for WII uptake, since both improve farmers' resilience but at different levels of risk. Extension might promote technologies that have a risk management component (e.g., irrigation). On the other hand, WII tends to mitigate covariate weather risks that are difficult to effectively manage through on-farm strategies (Barnett and Mahul, 2007). However, a possible reason could be that public extension officers do not necessarily promote the WII products, so that farmers who are more in contact with extension officers may not as such be well informed about WII, hence the negative influence of extension on insurance uptake.

Membership in producer groups seems to improve WII uptake by about 10 percentage points. This is not surprising given the vital role that producer organizations play in promoting information flow on new innovations and market access (Shiferaw et al., 2009; Fischer and Qaim, 2012). Farmers who actively participate in groups may be better informed about index insurance not only because they are easily reached by insurance providers, but also due to learning and discussing the complexities with fellow group 
members which raises their likelihood of adoption. Finally, WII uptake is influenced by the ease of transportation according to the results in Table 3.3. Households owning private means of transportation such as bicycles, motorcycles, or vehicles incur less in terms of time and money to get to public gatherings or to reach major markets. This increases their likelihood of adopting agricultural innovations, compared to those who entirely rely on public transportation.

\subsubsection{Intensity of input use}

In order to measure the average effect of WII uptake on demand for purchased inputs, we estimate endogenous treatment regression models as explained before. We show regression results for inorganic fertilizer and improved seed (Table 3.4), since they are the two main purchased inputs used by smallholder farmers. Maize seed was deliberately measured in monetary terms because some farmers use recycled seeds while others use certified seeds, hence monetary measurement accounts for quality as well. To value recycled seeds we used the grain price which reflects the opportunity cost. From Table 3.4, the parameter athrho at the bottom of the table is statistically significant in both models. This shows there is evidence of selection bias meaning ordinary least square estimates would have been biased. Negative rho signs also have important implications of negative selection bias (Kabunga et al., 2014); meaning that farmers taking-up WII are likely to be those who ordinarily use inputs less intensively.

Concentrating on the outcome equations (Column 1 and 3) the results indicate that other factors being constant, WII uptake increases the intensity of fertilizer used on maize by 51\% [100 (exp(0.409)-1)] relative to not being insured. Similarly, WII increases investment in quality maize seed by 65\% [100 $(\exp (0.500)-1)]$. These effects are substantially large, indicating that weather risk is a major problem affecting the usage of purchased inputs in the study area. Similar positive effects of index insurance on fertilizer and seed expenditure have also been reported in Ghana and Ethiopia although based on pilot experiments (Karlan et al., 2014; Berhane et al., 2015). 
Table 3.4: Treatment-effect regression estimates: Intensity of inorganic fertilizer and maize seed

\begin{tabular}{|c|c|c|c|c|}
\hline Variables & $\begin{array}{c}\text { Fertilizer } \\
(\log , \mathrm{kg} / \text { acre })\end{array}$ & $\begin{array}{c}\text { WII } \\
\text { Uptake }\end{array}$ & $\begin{array}{c}\text { Maize seed } \\
\text { (log,'000ksh/acre) }\end{array}$ & $\begin{array}{c}\text { WII } \\
\text { Uptake }\end{array}$ \\
\hline WII uptake (dummy) & $\begin{array}{c}0.409 * * \\
(0.205)\end{array}$ & & $\begin{array}{c}0.500^{* *} \\
(0.228)\end{array}$ & \\
\hline Age of farmer (years) & $\begin{array}{c}-0.010^{* * *} \\
(0.004)\end{array}$ & $\begin{array}{c}0.021^{* * *} \\
(0.007)\end{array}$ & $\begin{array}{l}-0.005^{*} \\
(0.002)\end{array}$ & $\begin{array}{c}0.021^{* * *} \\
(0.007)\end{array}$ \\
\hline Age squared & $\begin{array}{l}0.0003^{*} \\
(0.0001)\end{array}$ & $\begin{array}{l}-0.0007^{*} \\
(0.0003)\end{array}$ & $\begin{array}{l}0.0002 * \\
(0.0001)\end{array}$ & $\begin{array}{c}-0.0007^{* *} \\
(0.0004)\end{array}$ \\
\hline Education of farmer (years) & $\begin{array}{c}0.001 \\
(0.016)\end{array}$ & $\begin{array}{c}0.014 \\
(0.022)\end{array}$ & $\begin{array}{c}0.011 \\
(0.008)\end{array}$ & $\begin{array}{c}0.012 \\
(0.023)\end{array}$ \\
\hline Cultivated area (acres) & $\begin{array}{c}-0.048 * * \\
(0.022)\end{array}$ & $\begin{array}{c}0.053 \\
(0.040)\end{array}$ & $\begin{array}{l}-0.031 \\
(0.020)\end{array}$ & $\begin{array}{c}0.047 \\
(0.046)\end{array}$ \\
\hline $\begin{array}{l}\text { Male labor endowment } \\
\text { (adult males/area) }\end{array}$ & $\begin{array}{c}0.106 * * * \\
(0.030)\end{array}$ & $\begin{array}{l}-0.042 \\
(0.101)\end{array}$ & $\begin{array}{c}0.060 * * * \\
(0.020)\end{array}$ & $\begin{array}{l}-0.079 \\
(0.104)\end{array}$ \\
\hline $\begin{array}{l}\text { Female labor endowment } \\
\text { (adult females/area) }\end{array}$ & $\begin{array}{c}0.030 \\
(0.040)\end{array}$ & $\begin{array}{c}-0.244^{* *} \\
(0.114)\end{array}$ & $\begin{array}{c}0.022 \\
(0.028)\end{array}$ & $\begin{array}{l}-0.192 \\
(0.118)\end{array}$ \\
\hline Livestock value (log, '000 Ksh) & $\begin{array}{c}0.157 * * * \\
(0.044)\end{array}$ & $\begin{array}{c}0.029 \\
(0.073)\end{array}$ & $\begin{array}{c}0.051^{* *} \\
(0.020)\end{array}$ & $\begin{array}{c}0.025 \\
(0.070)\end{array}$ \\
\hline Risk neutral $(5 \leq \text { WTP } \leq 6)^{\text {a }}$ & $\begin{array}{c}0.225 \\
(0.153)\end{array}$ & $\begin{array}{l}-0.700^{* * *} \\
(0.255)\end{array}$ & $\begin{array}{c}0.146 \\
(0.092)\end{array}$ & $\begin{array}{c}-0.666 * * * \\
(0.247)\end{array}$ \\
\hline Risk loving $(7 \leq \mathrm{WTR} \leq 10)$ & $\begin{array}{l}0.274^{* *} \\
(0.130)\end{array}$ & $\begin{array}{c}-0.460 * * \\
(0.213)\end{array}$ & $\begin{array}{c}0.146 * * \\
(0.067)\end{array}$ & $\begin{array}{c}-0.446^{* *} \\
(0.208)\end{array}$ \\
\hline Crop diversification (crop count) & $\begin{array}{c}0.064 \\
(0.046)\end{array}$ & $\begin{array}{l}-0.072 \\
(0.092)\end{array}$ & $\begin{array}{c}0.064^{* *} \\
(0.028)\end{array}$ & $\begin{array}{c}-0.050 \\
(0.091)\end{array}$ \\
\hline Share of off-farm income (\%) & $\begin{array}{c}0.089 \\
(0.146)\end{array}$ & $\begin{array}{l}-0.407 \\
(0.264)\end{array}$ & $\begin{array}{c}0.098 \\
(0.092)\end{array}$ & $\begin{array}{l}-0.344 \\
(0.262)\end{array}$ \\
\hline Access to credit (dummy) & $\begin{array}{l}-0.011 \\
(0.092)\end{array}$ & $\begin{array}{c}0.091 \\
(0.171)\end{array}$ & $\begin{array}{c}0.011 \\
(0.058)\end{array}$ & $\begin{array}{c}0.119 \\
(0.166)\end{array}$ \\
\hline Agricultural extension (contacts) & $\begin{array}{c}0.026 * * * \\
(0.007)\end{array}$ & $\begin{array}{c}-0.052^{*} \\
(0.030)\end{array}$ & $\begin{array}{c}0.005 \\
(0.007)\end{array}$ & $\begin{array}{c}-0.042 \\
(0.029)\end{array}$ \\
\hline Own transportation means (dummy) & $\begin{array}{c}0.097 \\
(0.099)\end{array}$ & $\begin{array}{c}0.300 \\
(0.193)\end{array}$ & $\begin{array}{l}-0.044 \\
(0.065)\end{array}$ & $\begin{array}{l}0.312^{*} \\
(0.188)\end{array}$ \\
\hline Time taken to input market (log, minutes) & $\begin{array}{c}-0.218^{* * *} \\
(0.064)\end{array}$ & $\begin{array}{l}-0.091 \\
(0.109)\end{array}$ & $\begin{array}{c}-0.069 * * \\
(0.035)\end{array}$ & $\begin{array}{c}-0.062 \\
(0.110)\end{array}$ \\
\hline Fertilizer price (log, Ksh/kg) & $\begin{array}{c}-1.114^{* *} \\
(0.538)\end{array}$ & $\begin{array}{c}0.015 \\
(1.150)\end{array}$ & $\begin{array}{c}0.282 \\
(0.380)\end{array}$ & $\begin{array}{c}0.170 \\
(1.143)\end{array}$ \\
\hline Received WII training (dummy) & & $\begin{array}{c}0.837 * * * \\
(0.168)\end{array}$ & & $\begin{array}{c}0.804 * * * \\
(0.160)\end{array}$ \\
\hline Location dummies included & [Yes] & [Yes] & [Yes] & [Yes] \\
\hline Constant & $\begin{array}{c}8.084^{* * * *} \\
(2.283)\end{array}$ & $\begin{array}{l}-0.195 \\
(4.842)\end{array}$ & $\begin{array}{l}-0.463 \\
(1.600)\end{array}$ & $\begin{array}{l}-0.971 \\
(4.861)\end{array}$ \\
\hline ath(rho) & $\begin{array}{c}-0.257^{*} \\
(0.132)\end{array}$ & & $\begin{array}{c}-0.597^{*} \\
(0.313)\end{array}$ & \\
\hline $\ln (\operatorname{sigma})$ & $\begin{array}{l}-0.155^{* *} \\
(0.0636)\end{array}$ & & $\begin{array}{c}-0.674 * * * \\
(0.069)\end{array}$ & \\
\hline Wald test of independent equations & $3.79 *$ & & $3.63 *$ & \\
\hline
\end{tabular}


Results on the other determinants indicate that age of the farmer negatively influences the intensity of fertilizer and seed investment. Much younger farmers are known to be more willing to adopt technologies due to being aware of modern farming approaches. However, the influence of age is nonlinear: results show that much older farmers would also apply fertilizer more intensively since they have farming experience and better understanding of the importance of fertilizer in maize productivity. In addition, smaller farms apply fertilizer more intensively than larger farms. This is because farmers tend to experiment with small doses of fertilizer over a large area (Nkonya et al., 1997). It could also be because of higher pressure on land for smaller farms which pushes them to apply productive inputs more intensively.

Further results show that male family labor improves fertilizer and seed use by more than $6 \%$. Households endowed with family labor can allocate more resources into purchasing productive inputs, as they spend relatively less on hired labor (Abdulai and Huffman, 2014). More so the male labor force is important in this regard because of their strength and often less involvement in other household chores. The coefficient for livestock ownership is also positive and significant. Livestock can be a proxy for wealth in rural settings where households generally own few assets. In addition, income from livestock products might serve as additional capital that improves the intensity of inputs applied on maize.

Risk attitude is another factor that affects input usage based on the results in Table 3.4. Specifically, risk loving individuals apply more fertilizer and invest in maize seed more than the risk averse. Using improved seeds and inorganic fertilizer is known to enhance maize yields (Duflo et al., 2008). Nonetheless, it also leads to lower returns under unfavorable rainfall; which discourages intensive usage by risk averse farmers (Feder et al., 1985; Alem et al., 2010). On the contrary, risk management at the farm level could encourage the demand for modern inputs. Results show that crop enterprise diversification significantly increases maize seed investments. Diversification is a strategy for reducing risk yet it may also limit the productivity of each crop, especially if farmers practice mixed cropping. Hence it is possible that diversified farms have greater incentive to use quality seed also so as to compensate for the loss in productivity. 
In terms of institutional factors, the intensity of using fertilizer increases with access to agricultural extension. This is expected because the Kenyan Ministry of Agriculture has been promoting fertilizer use on maize to improve the country's food security (Mason et al., 2016). Surprising though, extension has no significant influence on seed investment. Distance to the market is also seen to affect input use in a negative way. Farmers located closer to the input market apply fertilizer and invest in seeds more intensively, which results from better access to market information and lower transaction costs (Alene et al., 2008). Lastly, fertilizer price has a negative and significant coefficient as expected. An increase in price by $1 \%$ results in a decrease in fertilizer use by more than $1 \%$, implying that fertilizer demand is elastic to its price. Both models also include village dummy variables to control for unobserved village level differences for example in soil quality, road infrastructure, or agro-climatic conditions which we were unable to capture in the data.

\subsubsection{Maize productivity}

Having established that WII indeed affects input use, we estimate a maize production model to show whether those input-use effects lead to significant yield gains. We use a Cobb-Douglas specification where both maize yield and production inputs are in natural logs. In addition, we include dummy variables for inputs that are not used by all farmers (following Battese, 1997), as well as other control variables. Table 3.5 presents results of the treatment regression model. To economize on space the table only presents results of the outcome equation. The first stage (WII uptake) results are shown in the Appendix [Table A3].

Results in Column 1 (Table 3.5) indicate that WII has a positive and significant effect on maize productivity. Specifically, other factors being held constant, purchasing WII increases maize yields by about $62 \%$ [100 (exp(0.485)-1)], which is a substantial effect. This clearly demonstrates that WII programs can contribute to an increase in crop productivity. We have not included production inputs in Column 1 because we expect the yield effect to be channeled through input use. In Columns 2-6 we add the inputs in a step-wise fashion to investigate the main source of the effect. Labor and manure are both 
significant inputs determining maize productivity. Pesticide on the other hand does not significantly influence maize yield in this context. Addition of these three inputs leads to a decrease in the WII effect, however, the decrease is relatively small and the coefficient remains positive and significant. As we add fertilizer and then seed to the regression, the WII coefficient drastically decreases and becomes insignificant. This shows that WII affects crop productivity mainly through enhancing the intensity of external inputs. In other words, as a result of taking-up index insurance farmers allocate more resources into purchasing fertilizer and quality seed which in turn improve the yields of their farms compared to the situation without insurance.

Moreover, results in Column 6 also indicate that fertilizer has the largest production elasticity among all inputs. On average an increase in fertilizer by $1 \%$ increases maize yield in the area by $0.4 \%$. Improved seeds $(0.17 \%)$, labor $(0.14 \%)$, and manure $(0.11 \%)$ also contribute significantly to maize productivity in the study area. Policies that promote adequate allocation of these inputs could therefore contribute towards improving maize production in general. An issue of concern for sustainability is that WII provision might crowd out manure. We tested and found a negative effect of WII uptake on manure use (results in Appendix A4). It is usually recommended that farmers combine inorganic fertilizer with manure and other agronomic practices so as to maintain the soil organic matter and fertility in the long term (Holden and Lunduka, 2012; Wainaina et al., 2016). This however does not seem to occur in this case since insured farmers substitute inorganic fertilizer for manure which increases yields but might not guarantee a long term productivity improvement for the smallholder farmers. Since both inorganic fertilizer and manure significantly influence maize yields (Table 3.5), it is important to educate farmers on the importance of appropriately combining them where possible so as to maximize their yield potential. 
Table 3.5: Treatment-effect regression estimates: WII effect on maize yields (log, kg/acre)

\begin{tabular}{|c|c|c|c|c|c|c|}
\hline Variables & [1] & [2] & [3] & [4] & [5] & {$[6]$} \\
\hline WII uptake (dummy) & $\begin{array}{c}0.485 * * \\
(0.246)\end{array}$ & $\begin{array}{l}0.433^{*} \\
(0.245)\end{array}$ & $\begin{array}{c}0.453^{* *} \\
(0.210)\end{array}$ & $\begin{array}{l}0.423 * \\
(0.228)\end{array}$ & $\begin{array}{l}-0.538 \\
(1.037)\end{array}$ & $\begin{array}{l}-0.605 \\
(0.584)\end{array}$ \\
\hline Seed (log, '000 Ksh/acre) & & & & & & $\begin{array}{c}0.172 * * \\
(0.072)\end{array}$ \\
\hline Fertilizer (log, kg/acre) & & & & & $\begin{array}{c}0.492 * * * \\
(0.099)\end{array}$ & $\begin{array}{c}0.442 * * * \\
(0.081)\end{array}$ \\
\hline Fertilizer not used (dummy) & & & & & $\begin{array}{c}-1.012 * * * \\
(0.370)\end{array}$ & $\begin{array}{c}-1.017^{* * *} \\
(0.380)\end{array}$ \\
\hline Pesticide (log, '000 Ksh/acre) & & & & $\begin{array}{c}0.019 \\
(0.050)\end{array}$ & $\begin{array}{l}-0.014 \\
(0.052)\end{array}$ & $\begin{array}{l}-0.012 \\
(0.048)\end{array}$ \\
\hline Pesticide not used (dummy) & & & & $\begin{array}{c}-0.180^{*} \\
(0.097)\end{array}$ & $\begin{array}{l}-0.076 \\
(0.092)\end{array}$ & $\begin{array}{l}-0.060 \\
(0.094)\end{array}$ \\
\hline Manure (log, MT/acre) & & & $\begin{array}{c}0.168^{* * *} \\
(0.058)\end{array}$ & $\begin{array}{c}0.158 * * * \\
(0.058)\end{array}$ & $\begin{array}{c}0.133 * * \\
(0.057)\end{array}$ & $\begin{array}{l}0.106^{*} \\
(0.056)\end{array}$ \\
\hline Manure not used (dummy) & & & $\begin{array}{c}-0.074 \\
(0.083)\end{array}$ & $\begin{array}{l}-0.063 \\
(0.083)\end{array}$ & $\begin{array}{c}0.022 \\
(0.079)\end{array}$ & $\begin{array}{c}0.026 \\
(0.078)\end{array}$ \\
\hline Labor (log, man-days/acre) & & $\begin{array}{c}0.320 * * * \\
(0.073)\end{array}$ & $\begin{array}{c}0.299 * * * \\
(0.070)\end{array}$ & $\begin{array}{c}0.299 * * * \\
(0.070)\end{array}$ & $\begin{array}{c}0.176^{* *} \\
(0.073)\end{array}$ & $\begin{array}{l}0.140 * \\
(0.076)\end{array}$ \\
\hline Maize area (log, acres) & $\begin{array}{c}-0.470 * * * \\
(0.066)\end{array}$ & $\begin{array}{c}-0.290 * * * \\
(0.073)\end{array}$ & $\begin{array}{c}-0.231 * * * \\
(0.073)\end{array}$ & $\begin{array}{c}-0.227 * * * \\
(0.077)\end{array}$ & $\begin{array}{l}-0.005 \\
(0.171)\end{array}$ & $\begin{array}{c}0.019 \\
(0.121)\end{array}$ \\
\hline Male household head (dummy) & $\begin{array}{l}-0.020 \\
(0.097)\end{array}$ & $\begin{array}{l}-0.004 \\
(0.095)\end{array}$ & $\begin{array}{c}0.010 \\
(0.092)\end{array}$ & $\begin{array}{l}-0.003 \\
(0.092)\end{array}$ & $\begin{array}{l}-0.136 \\
(0.124)\end{array}$ & $\begin{array}{l}-0.133 \\
(0.101)\end{array}$ \\
\hline Education of farmer (years) & $\begin{array}{c}0.030 * * \\
(0.015)\end{array}$ & $\begin{array}{l}0.027^{*} \\
(0.015)\end{array}$ & $\begin{array}{l}0.024 * \\
(0.014)\end{array}$ & $\begin{array}{c}0.021 \\
(0.014)\end{array}$ & $\begin{array}{c}0.026 * * \\
(0.013)\end{array}$ & $\begin{array}{l}0.024^{*} \\
(0.013)\end{array}$ \\
\hline Age of farmer (years) & $\begin{array}{l}-0.0002 \\
(0.004)\end{array}$ & $\begin{array}{l}-0.0001 \\
(0.004)\end{array}$ & $\begin{array}{l}0.0003 \\
(0.004)\end{array}$ & $\begin{array}{l}0.0004 \\
(0.004)\end{array}$ & $\begin{array}{c}0.007 \\
(0.006)\end{array}$ & $\begin{array}{l}0.008 * \\
(0.004)\end{array}$ \\
\hline Off-farm occupation (dummy) & $\begin{array}{c}0.196 * * \\
(0.090)\end{array}$ & $\begin{array}{c}0.209 * * \\
(0.087)\end{array}$ & $\begin{array}{c}0.199 * * \\
(0.086)\end{array}$ & $\begin{array}{c}0.195 * * \\
(0.085)\end{array}$ & $\begin{array}{c}0.208 * * \\
(0.088)\end{array}$ & $\begin{array}{c}0.219 * * \\
(0.088)\end{array}$ \\
\hline Livestock value ('000 Ksh) & $\begin{array}{c}0.005^{* * *} \\
(0.0008)\end{array}$ & $\begin{array}{c}0.004 * * * \\
(0.0008)\end{array}$ & $\begin{array}{l}0.004 * * * \\
(0.0008)\end{array}$ & $\begin{array}{l}0.003^{* * *} \\
(0.0008)\end{array}$ & $\begin{array}{c}0.003^{* * *} \\
(0.0007)\end{array}$ & $\begin{array}{c}0.003 * * * \\
(0.0007)\end{array}$ \\
\hline $\begin{array}{l}\text { Frequency of droughts } \\
\text { (past } 5 \text { years) }\end{array}$ & $\begin{array}{l}-0.028 \\
(0.026)\end{array}$ & $\begin{array}{l}-0.037 \\
(0.025)\end{array}$ & $\begin{array}{l}-0.040 \\
(0.025)\end{array}$ & $\begin{array}{l}-0.043^{*} \\
(0.025)\end{array}$ & $\begin{array}{c}-0.051^{* *} \\
(0.026)\end{array}$ & $\begin{array}{c}-0.047^{*} \\
(0.025)\end{array}$ \\
\hline $\begin{array}{l}\text { Owns irrigation equipment } \\
\text { (dummy) }\end{array}$ & $\begin{array}{c}0.603^{* * *} \\
(0.122)\end{array}$ & $\begin{array}{c}0.587 * * * \\
(0.110)\end{array}$ & $\begin{array}{c}0.526^{* * *} \\
(0.115)\end{array}$ & $\begin{array}{c}0.524 * * * \\
(0.116)\end{array}$ & $\begin{array}{c}0.553^{* * *} \\
(0.162)\end{array}$ & $\begin{array}{c}0.533^{* * *} \\
(0.151)\end{array}$ \\
\hline Agricultural extension (contacts) & $\begin{array}{l}-0.005 \\
(0.011)\end{array}$ & $\begin{array}{l}-0.006 \\
(0.011)\end{array}$ & $\begin{array}{l}-0.005 \\
(0.012)\end{array}$ & $\begin{array}{l}-0.007 \\
(0.012)\end{array}$ & $\begin{array}{l}-0.016 \\
(0.013)\end{array}$ & $\begin{array}{l}-0.015 \\
(0.013)\end{array}$ \\
\hline $\begin{array}{l}\text { Time taken to input market } \\
\text { (log, minutes) }\end{array}$ & $\begin{array}{l}-0.106^{*} \\
(0.059)\end{array}$ & $\begin{array}{c}-0.112^{*} \\
(0.058)\end{array}$ & $\begin{array}{l}-0.100^{*} \\
(0.057)\end{array}$ & $\begin{array}{l}-0.099 * \\
(0.058)\end{array}$ & $\begin{array}{l}-0.035 \\
(0.055)\end{array}$ & $\begin{array}{l}-0.025 \\
(0.055)\end{array}$ \\
\hline Location dummies included & [Yes] & [Yes] & [Yes] & [Yes] & [Yes] & [Yes] \\
\hline Constant & $\begin{array}{c}-0.704 * * \\
(0.279)\end{array}$ & $\begin{array}{l}-0.506^{*} \\
(0.282)\end{array}$ & $\begin{array}{l}-0.501^{*} \\
(0.279)\end{array}$ & $\begin{array}{l}-0.404 \\
(0.285)\end{array}$ & $\begin{array}{l}-0.500^{*} \\
(0.297)\end{array}$ & $\begin{array}{l}-0.495^{*} \\
(0.282)\end{array}$ \\
\hline ath(rho) & $\begin{array}{l}-0.231 \\
(0.182)\end{array}$ & $\begin{array}{l}-0.200 \\
(0.189)\end{array}$ & $\begin{array}{l}-0.223 \\
(0.159)\end{array}$ & $\begin{array}{l}-0.206 \\
(0.172)\end{array}$ & $\begin{array}{c}0.619 \\
(1.063)\end{array}$ & $\begin{array}{c}0.679 \\
(0.613)\end{array}$ \\
\hline $\ln (\operatorname{sigma})$ & $\begin{array}{c}-0.250 * * * \\
(0.051)\end{array}$ & $\begin{array}{c}-0.280 * * * \\
(0.049)\end{array}$ & $\begin{array}{c}-0.290 * * * \\
(0.049)\end{array}$ & $\begin{array}{c}-0.297 * * * \\
(0.050)\end{array}$ & $\begin{array}{l}-0.327 \\
(0.216)\end{array}$ & $\begin{array}{c}-0.325^{* *} \\
(0.140)\end{array}$ \\
\hline Wald test of independent equations & 1.61 & 1.12 & 1.97 & 1.43 & 0.34 & 1.23 \\
\hline
\end{tabular}

Notes: Shown are coefficients with standard errors in parenthesis. First stage results are shown in the Appendix (Table A3). Number of observations is 382 (for farmers growing maize). ${ }^{* * *}$, **, and * indicate significance at $1 \%$, $5 \%$, and $10 \%$ levels, respectively. 


\subsection{Conclusions}

Agricultural intensification is necessary for achieving rapid productivity growth in a manner that will sustainably meet demands of the rising population. Particularly for sub-Saharan Africa (SSA), fertilizer and modern varieties are often advocated to boost productivity growth and food security in the region. Yet because of weather-related risks, and other factors, farmers usually under-apply these inputs which limits their productivity potential. One way to support smallholder farmers is through expanding the markets for agricultural insurance. The objectives of this paper were to analyze the factors influencing WII uptake and the effect of insurance on input use and productivity. We have contributed to the scarce literature on this topic by using survey data of smallholder farmers in Kenya, who had participated in a commercial WII scheme. To control for endogeneity and self-selection bias we applied a treatment regression model with instrumental variables.

Empirical results revealed a significant increase in fertilizer use and seed investments as a result of purchasing WII. These effects were analyzed specifically for maize because it is a staple food crop grown by the majority of farmers in Kenya. Controlling for other factors, WII uptake was found to increase the intensity of fertilizer and seeds by 50 and 65\% respectively. Insurance uptake is also associated with improvement in maize yields by almost $60 \%$. Further analysis on the source of the yield effects confirmed that WII was indeed increasing maize yields through its influence on the use of purchased inputs. This increased usage of external inputs might result in substitution of locally available inputs; hence further research on potential unintended effects on productivity could be useful. Furthermore, the magnitudes of the WII effects are substantial in the specific case of Kenya, since input markets are better developed than many other countries in SSA, and also because there is pre-existing demand for fertilizer. Therefore these findings may not be generalizable to other marginalized areas in Kenya, or to other SSA countries. Further research is required in different agro-climatic conditions and institutional contexts. Still, our findings show that novel risk-transfer instruments such as WII provide a lot of promise. Through offering insurance smallholder farmers can be encouraged to utilize modern 
technologies by simply reducing the burden of weather risk. This potential has, however, not fully been realized because at the moment only a small fraction of farmers purchase WII products.

It is important to educate farmers about this relatively unfamiliar type of insurance. Although insurance providers currently offer some training as part of marketing, the "public good" nature of the investment limits the extent to which a private company would be involved. Thus public support might be required for capacity building. In addition, there is need to harmonize agricultural extension with WII training initiatives to strengthen the roles played by each. This can be achieved through public-private partnerships. Furthermore, results suggest the need to empower producer groups and to nurture farmer-tofarmer knowledge exchange within these group networks to improve the general understanding of index insurance amongst rural communities.

Besides insurance, there are still other mechanisms for encouraging input intensification without the need for input subsidies or other market distorting interventions. Results point at factors such as market distance and fertilizer prices, both of which contribute to the transaction costs of purchasing inputs. Government can intervene by improving transport and market infrastructure into rural areas which will allow input prices to come down through a competitive market environment. 


\section{Chapter 4: Conclusions and Policy Implications}

\subsection{Main findings}

Uninsured risk is a major cause of persistent poverty in rural areas of developing countries, where farming is predominantly rain-fed, and where agriculture is the main source of livelihood. To cushion producers from devastating weather events, governments and donor agencies have widely piloted weather index insurance (WII) in several lower-income countries. WII could reduce the high transaction costs that have traditionally hindered the development of agricultural insurance in these countries. In this study, we have focused on the Kilimo Salama WII Program in Kenya, which was initiated in 2009 by the Syngenta Foundation to provide index-based crop insurance products for smallholder farmers.

A common observation from pilot WII programs, is that uptake of insurance products among smallholder farmers is usually much lower than expected. Even for the case of Kilimo Salama, although this Program has shown impressive growth within only a few years, the fraction of farmers that have actually purchased WII contracts remains relatively small. Moreover, some of the previously insured farmers dropped out after one or two years of participating in the Program, showing that not all farmers are satisfied with their WII experience. In Chapter 2, we have argued and shown based on farmer responses that insurance contracts are probably not sufficiently tailored to the needs and expectations of smallholder farmers. We have also used choice-experimental methods to analyze farmers' preferences and how hypothetical changes in contractual design might help towards more widespread WII uptake. A mixed logit model that accommodates varying preferences of farmers was applied in the econometric analysis.

Estimation results show that smallholder farmers have a positive overall attitude towards WII. However, the existing insurance contracts are probably too expensive, since the mean willingness to pay (WTP) was about 25\% lower than the average premium rate charged by the insurance provider. In addition, other non-price attributes also seemed critical from farmers’ point of view. Specifically, farmers have a strong preference for transparency and frequent communication from the insurer. Sending regular 
text messages that provide relevant rainfall measurements and thresholds could significantly improve farmers' WTP for insurance. Second, basis risk is often cited as a major obstacle in designing WII contracts. Results have shown that reducing spatial basis risk - for example through shorter distances to weather stations - could actually increase the WTP for insurance. However, this effect on WTP is smaller than the one resulting from higher levels of transparency. Third, farmers are willing to pay more for insurance contracts that already trigger pay-outs for relatively less severe weather events. Such events occur more frequently, meaning that pay-outs would also be more frequent over the years than when only triggered in case of very severe weather shocks. Contracts that make small but frequent pay-outs seem to be more trust-building for smallholder farmers, since many of them still struggle with understanding how the insurance actually works. Finally, WII contracts offered to farmer groups attract a significantly higher WTP than individual contracts. But smaller groups are more preferred over large groups, probably because the latter have less cohesion among members.

After gaining insights from farmer preferences, in Chapter 3 we have analyzed WII adoption and its effect on input use and productivity. WII initiatives can contribute in multiple ways towards poverty reduction and development; one way is through encouraging farm investments in environments that are prone to weather risks. The literature on socio-economic impacts of actually existing WII programs is still scarce. Thus, we have contributed towards this knowledge gap by specifically analyzing how WII affects the intensity of purchased inputs and the resulting effects on maize productivity. Unlike several previous studies that identified WII effects within randomized field experiments, we have used observational data from a farm survey in Kenya, where the Kilimo Salama Program has been marketing WII products for more than five years. In the econometric analysis we have applied a treatment regression model with instrumental variables, to account for endogeneity and possible self-selection bias that may arise in WII adoption.

Estimation results indicate a positive and significant increase in the intensity of fertilizer and improved maize seed as a result of purchasing WII. Specifically, the effect of WII uptake on the use of these purchased inputs was in the range of $50-65 \%$, which is a large effect considering that risk is only one 
out of many factors that influence fertilizer and improved seed usage. Other factors that we controlled for in the econometric analysis are human capital, labor endowment, farm size, location, as well as information and market access, among others. Further analysis has revealed that WII improves maize productivity by about $60 \%$, which mainly comes through enhanced fertilizer application and better quality seeds. Thus we provide evidence that WII can contribute significantly towards higher crop productivity in small-farm contexts.

\subsection{Policy implications}

Many developing countries have recently witnessed marked progress in the fight against hunger and poverty, yet most countries in sub-Saharan Africa (SSA) have lagged behind because of rapid population growth and low productivity development in agriculture. There is a drive to promote fertilizer and modern varieties in an effort to rapidly raise yields in SSA. A common policy strategy is often to subsidize fertilizer and certified seeds, but such subsidies have been heavily contested. Our findings suggest that there are other mechanisms for supporting smallholder farmers such as through WII programs. Provision of WII in rural areas, where farmers lack other types of formal insurance, can open up agricultural investments and credit markets to farmers. These shifts in farm investments and capital have the potential of creating improvements in productivity in a sizeable dimension, as shown in this

study. But for this potential to be fully realized, WII programs have to expand and reach farmers at broader scale. At the moment, only a small proportion of farmers purchase WII products.

A starting point in attracting farmers to take up WII is to make premiums more affordable where this is possible. Farmers will also develop more confidence in the insurance if there is transparent provision of relevant information and frequent communication from the insurance provider. Sending regular text messages to insured farmers may not cost very much for the insurance provider, but could significantly help to build trust and encourage further insurance uptake, as the choice experimental results underline. In addition, there is need for increased training to improve farmers' understanding of this novel type of insurance. For this, public support might be required since capacity building helps to develop the 
overall WII market and does not only benefit a specific insurance company. Moreover, widespread insurance adoption can be achieved by offering group insurance contracts, and strengthening the functions of producer groups in rural areas. A group approach can reduce marketing and program implementation costs for the insurer, while allowing farmers to exchange knowledge within group networks. Also, providing insurance at group level may help to internalize individual risks which are not usually covered by a WII contract.

\subsection{Limitations of the study}

While this study has provided useful insights into typical issues of WII programs in a small-farm context, it is important to note a few limitations of this research. First, we used a discrete choice experiment (DCE) to assess how farmers value different design attributes in WII contracts. But DCE data may be subject to hypothetical bias in the sense that farmers may portray higher WTP than they would in an actual insurance purchase situation. Therefore, while the directions of the results and the relative rankings between contract design attributes should be in order, the exact WTP estimates should not be over-interpreted. Second, related to the WII effects on input use and productivity, our study was undertaken in one part of Kenya where there was pre-existing demand for fertilizer, so that WII was useful in improving the intensity of use. In other areas, where input markets are less developed, or where it is economically not rational to apply higher levels of fertilizer, WII alone may not lead to significant improvements in productivity. Third, the analysis here builds on cross-section observational data, which have their limitations in terms of addressing possible issues of selection bias.

Further research is needed on farmers' preferences in different environmental and social-cultural settings, so as to design contracts that are better tailored to farmers' needs. More research on the impacts of already existing WII programs is also required. We have only measured WII effects using the example of maize in one particular region of Kenya. It would be useful to explore WII effects for other crops, other regions, and using panel datasets. With panel data one can better address issues of selection bias and also analyze dynamics of insurance participation and pay-outs over time. 


\section{References}

Abdulai, A., \& Huffman, W. (2014). The adoption and impact of soil and water conservation technology: An endogenous switching regression application. Land Economics, 90(1), 26-43.

Adamowicz, W., Boxall, P., Williams, M., \& Louviere, J. (1998). Stated preference approaches for measuring passive use values: Choice experiments and contingent valuation. American Journal of Agricultural Economics, 80(1), 64-75.

Akerlof, G. (1970). The market for lemons: Qualitative uncertainty and market mechanism. Quarterly Journal of Economics, 84(3), 488-500.

Akter, S., Krupnik, T.J., Rossi, F., \& Khanam, F. (2016). The influence of gender and product design on farmers’ preferences for weather-indexed crop insurance. Global Environmental Change 38: 217229.

Alem, Y., Bezabih, M., Kassie, M., \& Zikhali, P. (2010). Does fertilizer use respond to rainfall variability? Panel data evidence from Ethiopia. Agricultural Economics, 41(2), 165-175.

Alene, A.D., Manyong, V.M., Omanya, G., Mignouna, H.D., Bokanga, M., \& Odhiambo, G. (2008). Smallholder market participation under transactions costs: Maize supply and fertilizer demand in Kenya. Food policy, 33(4), 318-328.

Angrist, J.D., Imbens, G.W., \& Rubin, D.B. (1996). Identification of causal effects using instrumental variables. Journal of the American Statistical Association, 91(434), 444-455.

Anton, J., Cattaneo, A., Kimura, S., \& Lankoski, J. (2013). Agricultural risk management policies under climate uncertainty. Global Environmental Change, 23(6), 1726-1736.

Ariga, J., Jayne, T.S., Kibaara, B., \& Nyoro, J.K. (2008). Trends and patterns in fertilizer use by smallholder farmers in Kenya, 1997-2007. Nairobi: Tegemeo Institute of Agricultural Policy and Development, Egerton University.

Barnett, B.J., \& Mahul, O. (2007). Weather index insurance for agriculture and rural areas in lowerincome countries. American Journal of Agricultural Economics, 89(5), 1241-1247.

Barnett, B.J., Barrett, C.B., \& Skees, J.R. (2008). Poverty traps and index-based risk transfer products. World Development, 36(10), 1766-1785.

Battese, G.E. (1997). A note on the estimation of Cobb-Douglas production functions when some explanatory variables have zero values. Journal of Agricultural Economics, 48(1-3), 250-252.

Bech, M., \& Gyrd-Hansen, D. (2005). Effects coding in discrete choice experiments. Health Economics, 14(10), 1079-1083.

Berhane, G., Dercon, S., Hill, R.V., \& Taffesse, A. (2015). Formal and informal insurance: Experimental evidence from Ethiopia. Selected Paper for International Association of Agricultural Economists Conference, Milan, 9-14 August 2015. 
Binswanger-Mkhize, H.P. (2012). Is there too much hype about index-based agricultural insurance? Journal of Development Studies, 48(2), 187-200.

Boucher, S.R., Carter, M.R., \& Guirkinger, C. (2008). Risk rationing and wealth effects in credit markets: Theory and implications for agricultural development. American Journal of Agricultural Economics, 90(2), 409-423.

Breustedt, G., Bokusheva, R., \& Heidelbach, O. (2008). Evaluating the potential of index insurance schemes to reduce crop yield risk in an arid region. Journal of Agricultural Economics, 59(2), 312-328.

Brown, M.E., \& Kshirsagar, V. (2015). Weather and international price shocks on food prices in the developing world. Global Environmental Change, 35, 31-40.

Burney, J.A., Davis, S.J., \& Lobell, D.B. (2010). Greenhouse gas mitigation by agricultural intensification. Proceedings of the National Academy of Sciences, 107(26), 12052-12057.

Carter, M.R., \& Barrett, C.B. (2006). The economics of poverty traps and persistent poverty: An assetbased approach. Journal of Development Studies, 42(2), 178-199.

Carter, M.R., Barrett, C. B., Boucher, S., Chantarat, S., Galarza, F., McPeak, J., et al. (2008). Insuring the never before insured: Explaining index insurance through financial education games. BASIS Brief 2008-07, Madison: University of Wisconsin.

Carter, M.R., Cheng, L., \& Sarris, A. (2016). Where and how index insurance can boost the adoption of improved agricultural technologies. Journal of Development Economics, 118, 59-71.

Carter, M., de Janvry, A., Sadoulet, E., \& Sarris, A. (2014). Index-based weather insurance for developing countries: A review of evidence and a set of propositions for up-scaling. Foundation for International Development Study and Research (FERDI), Working paper No. 111.

Castellani, D., Viganò, L., \& Tamre, B. (2014). A discrete choice analysis of smallholder farmers' preferences and willingness to pay for weather derivatives: Evidence from Ethiopia. Journal of Applied Business Research, 30(6), 1671-1692.

Challinor, A.J., Koehler, A.K., Ramirez-Villegas, J., Whitfield, S., \& Das, B. (2016). Current warming will reduce yields unless maize breeding and seed systems adapt immediately. Nature Climate Change, DOI:10.1038/nclimate3061.

Chantarat, S., Mude, A.G., Barrett, C.B., \& Carter, M.R. (2013). Designing index-based livestock insurance for managing asset risk in Northern Kenya. Journal of Risk and Insurance, 80(1), 205237.

Clarke, D.J. (2016). A theory of rational demand for index insurance. American Economic Journal: Microeconomics, 8(1), 283-306.

Clarke, D.J., Mahul, O., Rao, K.N., \& Verma, N. (2012). Weather based crop insurance in India. Washington, DC: The World Bank, Policy research working paper No. 5985. 
Cole, S.A., Giné, X., Tobacman, J., Townsend, R., Topalova, P., \& Vickery, J.I. (2013). Barriers to household risk management: Evidence from India. American Economic Journal: Applied Economics, 5(1), 104-135.

Cooper, P.J., Dimes, J., Rao, K.P., Shapiro, B., Shiferaw, B., \& Twomlow, S. (2008). Coping better with current climatic variability in the rain-fed farming systems of sub-Saharan Africa: An essential first step in adapting to future climate change? Agriculture, Ecosystems \& Environment, 126(1), 24-35.

De Janvry, A., Dequiedt, V., \& Sadoulet, E. (2014). The demand for insurance against common shocks. Journal of Development Economics, 106, 227-238.

Delpierre, M., \& Boucher, S. (2013). The impact of index-based insurance on informal risk-sharing networks. Annual Meeting of Agricultural and Applied Economics Association, Washington, DC, 4-6 August, 2013.

Deng, X., Barnett, B.J., Vedenov, D.V., \& West, J.W. (2007). Hedging dairy production losses using weather-based index insurance. Agricultural Economics, 36(2), 271-280.

Denning, G., Kabambe, P., Sanchez, P., Malik, A., Flor, R., Harawa, R.N., et al. (2009). Input subsidies to improve smallholder maize productivity in Malawi: Toward an African Green Revolution. PLoS Biol, 7(1), e1000023.

Dercon, S. (2004). Growth and shocks: Evidence from rural Ethiopia. Journal of Development Economics, 74(2), 309-329.

Dercon, S.H., Clarke, D., Outes-Leon, I., \& Taffesse, A.S. (2014). Offering rainfall insurance to informal insurance groups: Evidence from a field experiment in Ethiopia. Journal of Development Economics, 106, 132-143.

Dercon, S., \& Christiaensen, L. (2011). Consumption risk, technology adoption, and poverty traps: Evidence from Ethiopia. Journal of Development Economics, 96(2), 159-173.

DFID. (2004). Agriculture, growth and poverty. London: The UK Department for International Development.

Di Falco, S., Veronesi, M., \& Yesuf, M. (2011). Does adaptation to climate change provide food security? A micro-perspective from Ethiopia. American Journal of Agricultural Economics, 93(3), 829-846.

Dohmen, T., Falk, A., Huffman, D., Sunde, U., Schupp, J., \& Wagner, G.G. (2011). Individual risk attitudes: Measurement, determinants, and behavioral consequences. Journal of the European Economic Association, 9(3), 522-550.

Elabed, G., \& Carter, M.R. (2015). Ex-ante impacts of agricultural insurance: Evidence from a field experiment in Mali. Davis: University of California.

Elabed, G., Bellemare, M.F., Carter, M.R., \& Guirkinger, C. (2013). Managing basis risk with multiscale index insurance. Agricultural Economics, 44(4-5), 419-431. 
Evenson, R.E., \& Gollin, D. (2003). Assessing the impact of the Green Revolution, 1960 to 2000. Science, 300(5620), 758-762.

FAO. (2015). The state of food and agriculture. Social protection and agriculture: Breaking the cycle of rural poverty. Rome: Food and Agriculture Organization of the United Nations.

FAO, IFAD, WFP. (2015). The state of food insecurity in the world. Meeting the 2015 international hunger targets: Taking stock of uneven progress. Rome: Food and Agriculture Organization of the United Nations.

Farrin, K., \& Miranda, M.J. (2015). A heterogeneous agent model of credit-linked index insurance and farm technology adoption. Journal of Development Economics, 116, 199-211.

Farrin, K., \& Murray, A.G. (2014). The effect of index insurance on returns to farm inputs: Exploring alternatives to Zambia's fertilizer subsidy program. Selected Paper for Agricultural and Applied Economics Association meeting, Minneapolis, 27-29 July 2014.

Feder, G., Just, R.E., \& Zilberman, D. (1985). Adoption of agricultural innovations in developing countries: A survey. Economic Development and Cultural Change, 33(2), 255-298.

Fischer, E., \& Qaim, M. (2012). Linking smallholders to markets: Determinants and impacts of farmer collective action in Kenya. World Development, 40(6), 1255-1268.

Fischer, E., \& Qaim, M. (2014). Smallholder farmers and collective action: What determines the intensity of participation? Journal of Agricultural Economics, 65(3), 683-702.

FSD. (2013). Review of FSD's index based weather insurance initiatives. Nairobi: Financial Sector Deepening.

Giné, X., \& Yang, D. (2009). Insurance, credit, and technology adoption: Field experimental evidence from Malawi. Journal of Development Economics, 89(1), 1-11.

Giné, X., Townsend, R., \& Vickery, J. (2008). Patterns of rainfall insurance participation in rural India. World Bank Economic Review, 22(3), 539-566.

Goodwin, B.K., Vandeveer, M.L., \& Deal, J.L. (2004). An empirical analysis of acreage effects of participation in the federal crop insurance progam. American Journal of Agricultural Economics, 86(4), 1058-1077.

Greatrex, H., Hansen, J.W., Garvin, S., Diro, R., \& Blakeley, S. (2015). Scaling up index insurance for smallholder farmers: Recent evidence and insights. CCAFS Report No. 14, Copenhagen: CGIAR Research Program on Climate Change, Agriculture and Food Security.

Greene, W.H. (2012). Regression analysis of treatment effects. In Econometric analysis (pp. 930-934). Edinburgh Gate: Prentice Hall.

Halcrow, H.G. (1949). Actuarial structures for crop insurance. Journal of Farm Economics, 31(3), 418443. 
Hanley, N., Mourato, S., \& Wright, R.E. (2001). Choice modelling approaches: A superior alternative for environmental valuatioin? Journal of Economic Surveys, 15(3), 435-462.

Hazell, P.B. (1992). The appropriate role of agricultural insurance in developing countries. Journal of International Development, 4(6), 567-581.

Hazell, P.B., \& Hess, U. (2010). Drought insurance for agricultural development and food security in dryland areas. Food Security, 2(4), 395-405.

Heckman, J.J. (1979). Sample Selection Bias as a Specification Error. Econometrica, 47(1), 153-161.

Heimfarth, L.E., \& Musshoff, O. (2011). Weather Index-based Insurances for Farmers in the North China Plain: An Analysis of Risk Reduction Potential and Basis Risk. Agricultural Finance Review, 71 (2): 218-239.

Hensher, D.A., Rose, J.M., \& Greene, W.H. (2005). Applied choice analysis: A primer. Cambridge: Cambridge University Press.

Hill, R., Hoddinott, J., \& Kumar, N. (2013). Adoption of weather-index insurance: Learning from willingness to pay among a panel of households in rural Ethiopia. Agricultural Economics , 44(45), 385-398.

Holden, S., \& Lunduka, R. (2012). Do fertilizer subsidies crowd out organic manures? The case of Malawi. Agricultural Economics, 43(3), 303-314.

Hole, A.R. (2007). Estimating mixed logit models using maximum simulated likelihood. The Stata Journal, 7(3), 388-401.

Hole, A.R., \& Kolstad, J.R. (2012). Mixed logit estimation of willingness to pay distributions: A comparison of models in preference and WTP space using data from a health-related choice experiment. Empirical Economics, 42(2), 445-469.

Hölmstrom, B. (1979). Moral hazard and observability. The Bell Journal of Economics, 10(1), 74-91.

Horowitz, J.K., \& Lichtenberg, E. (1993). Insurance, moral hazard, and chemical use in agriculture. American Journal of Agricultural Economics, 75(4), 926-935.

IFAD. (2010). The potential for scale and sustainability in weather index insurance for agriculture and rural livelihoods. Rome: International Fund for Agricultural Development and World Food Program.

IFC. (2015). Agriculture and Climate Risk Enterprise (ACRE) - Kilimo Salama - Kenya, Rwanda, Tanzania. Retrieved November 13, 2015, from International Finance Corporation: http://www.ifc.org

IPCC. (2012). Managing the risks of extreme events and disasters to advance climate change adaptation. A special report of the Intergovernmental Panel on Climate Change, Cambridge: Cambridge University Press. 
Jayne, T.S., \& Rashid, S. (2013). Input subsidy programs in sub-Saharan Africa: A synthesis of recent evidence. Agricultural Economics, 44(6), 547-562.

Jayne, T.S., Chamberlin, J., \& Headey, D.D. (2014). Land pressures, the evolution of farming systems, and development strategies in Africa: A synthesis. Food Policy, 48, 1-17.

Jayne, T.S., Govereh, J., Wanzala, M., \& Demeke, M. (2003). Fertilizer market development: A comparative analysis of Ethiopia, Kenya, and Zambia. Food Policy, 28(4), 293-316.

Jensen, N.D., Barrett, C.B., \& Mude, A.G. (2016). Index insurance quality and basis risk: Evidence from northern Kenya. American Journal of Agricultural Economics, DOI: 10.1093/ajae/aaw046.

Just, R.E., Calvin, L., \& Quiggin, J. (1999). Adverse selection in crop insurance: Actuarial and asymmetric information incentives. American Journal of Agricultural Economics, 81(4), 834-849.

Kabunga, N.S., Dubois, T., \& Qaim, M. (2014). Impact of tissue culture banana technology on farm household income and food security in Kenya. Food Policy, 25-34.

Karlan, D., Osei, R., Osei-Akoto, I., \& Udry, C. (2014). Agricultural decisions after relaxing credit and risk constraints. Quarterly Journal of Economics, 597-652.

Kellner, U., \& Musshoff, O. (2011). Precipitation or water capacity indices? An analysis of the benefits of alternative underlyings for index insurance. Agricultural Systems, 104(8), 645-653.

Kelly, V., Adesina, A.A., \& Gordon, A. (2003). Expanding access to agricultural inputs in Africa: A review of recent market development experience. Food Policy, 28(4), 379-404.

Kikulwe, E.M., Fischer, E., \& Qaim, M. (2014). Mobile money, smallholder farmers, and household welfare in Kenya. PloS ONE, 9(10), e109804.

Knox, J., Hess, T., Daccache, A., \& Wheeler, T. (2012). Climate change impacts on crop productivity in Africa and South Asia. Environmental Research Letters, 7(3), 034032.

Kouser, S., \& Qaim, M. (2013). Valuing financial, health, and environmental benefits of Bt cotton in Pakistan. Agricultural Economics, 44(3), 323-335.

Kuhfeld, W.F. (2010). Marketing research methods in SAS: Experimental design, choice, conjoint, and graphical techniques. Cary, NC: SAS-Institute.

Lesk, C., Rowhani, P., \& Ramankutty, N. (2016). Influence of extreme weather disasters on global crop production. Nature, 529(7584), 84-87.

Liebe, U., Maart, S.C., Mußhoff, O., \& Stubbe, P. (2012). Risk management on farms: An analysis of the acceptance of weather insurance using discrete choice experiments. German Journal of Agricultural Economics, 61(2), 63-79.

Liesivaara, P., \& Myyrä, S. (2014). Willingness to pay for agricultural crop insurance in the northern EU. Agricultural Finance Review, 74(4), 539-554.

Ligon, E., Thomas, J.P., \& Worrall, T. (2002). Informal insurance arrangements with limited commitment: Theory and evidence from village economies. Review of Economic Studies, 69(1), 209-244. 
Lipton, M. (2006). Can small farmers survive, prosper, or be the key channel to cut mass poverty? Electronic Journal of Agricultural and Development Economics, 3(1), 58-85.

Louviere, J.J., Hensher, D.A., \& Swait, J.D. (2000). Stated choice methods: Analysis and applications. Cambridge: Cambridge University Press.

Mahul, O., \& Stutley, C.J. (2010). Government support to agricultural insurance: Challenges and options for developing countries. Washington DC: The World Bank.

Mason, N.M., Wineman, A., Kirimi, L., \& Mather, D. (2016). The effects of Kenya's "smarter"input subsidy programme on smallholder behaviour and incomes: Do different quasi-experimental approaches lead to the same conclusions? Journal of Agricultural Economics, DOI: 10.1111/1477-9552.12159.

McIntosh, C., Povell, F., \& Sadoulet, E. (2015). Utility, risk, and demand for incomplete insurance: Lab experiments with Guatemalan cooperatives. San Diego: University of California.

Meijer, E., \& Rouwendal, J. (2006). Measuring welfare effects in models with random coefficients. Journal of Applied Econometrics, 21(2), 227-244.

Minten, B., \& Barrett, C.B. (2008). Agricultural technology, productivity, and poverty in Madagascar. World Development, 36(5), 797-822.

Miranda, M.J. (1991). Area-yield crop insurance reconsidered. American Journal of Agricultural Economics, 73(2), 233-242.

Miranda, M.J., \& Farrin, K. (2012). Index insurance for developing countries. Applied Economic Perspectives and Policy, 34(3), 391-427.

Miranda, M.J., \& Glauber, J.W. (1997). Systemic risk, reinsurance, and the failure of crop insurance markets. American Journal of Agricultural Economics, 79(1), 206-215.

Mishra, A.K., Nimon, R.W., \& El-Osta, H.S. (2005). Is moral hazard good for the environment? Revenue insurance and chemical input use. Journal of Environmental Management, 74(1), 11-20.

Mobarak, A.M., \& Rosenzweig, M. (2012). Selling formal insurance to the informally insured. Economic growth center discussion paper No. 1007, New Haven: Yale University.

Morduch, J. (1999). Between the state and the market: Can informal insurance patch the safety net? The World Bank Research Observer, 14(2), 187-207.

Morris, M.L., Kelly, V.A., Kopicki, R.J., \& Byerlee, D. (2007). Fertilizer use in African agriculture: Lessons learned and good practice guidelines. Washington DC: The World Bank.

Musshoff, O., Odening, M., \& Xu, W. (2011). Management of climate risks in agriculture: Will weather derivatives permeate? Applied Economics, 43(9), 1067-1077.

Ngetich, K.F., Mucheru-Muna, M., Mugwe, J.N., Shisanya, C.A., Diels, J., \& Mugendi, D.N. (2014). Length of growing season, rainfall temporal distribution, onset and cessation dates in the Kenyan highlands. Agricultural and Forest Meteorology, 188, 24-32. 
Nkonya, E., Schroeder, T., \& Norman, D. (1997). Factors affecting adoption of improved maize seed and fertiliser in Northern Tanzania. Journal of Agricultural Economics, 48(1-3), 1-12.

Norton, M.T., Turvey, C., \& Osgood, D. (2013). Quantifying spatial basis risk for weather index insurance. Journal of Risk Finance, 14(1), 20-34.

Norton, M., Osgood, D., Madajewicz, M., Holthaus, E., Peterson, N., Diro, R., et al. (2014). Evidence of demand for index insurance: Experimental games and commercial transactions in Ethiopia. Journal of Development Studies, 50(5), 630-648.

Omoyo, N.N., Wakhungu, J., \& Oteng'i, S. (2015). Effects of climate variability on maize yield in the arid and semi arid lands of lower eastern Kenya. Agriculture and Food Security, 4(8), DOI: 10.1186/s40066-015-0028-2

Otsuka, K., \& Larson, D.F. (Eds.) (2013). An African green revolution: Finding ways to boost productivity on small farms. Netherlands: Springer.

Patt, A., Peterson, N., Carter, M., Velez, M., Hess, U., \& Suarez, P. (2009). Making index insurance attractive to farmers. Mitigation and Adaptation Strategies for Global Change, 14(8), 737-753.

Patt, A., Suarez, P., \& Hess, U. (2010). How do small-holder farmers understand insurance, and how much do they want it? Evidence from Africa. Global Environmental Change, 20(1), 153-161.

Pingali, P.L. (2012). Green Revolution: Impacts, limits, and the path ahead. Proceedings of the National Academy of Sciences, 109(31), 12302-12308.

Rao, K.N. (2010). Index based crop insurance. Agriculture and Agricultural Science Procedia, 1, 193-203.

Reardon, T., Barrett, C., Kelly, V., \& Savadogo, K. (1999). Policy reforms and sustainable agricultural intensification in Africa. Development Policy Review, 17(4), 375-395.

Rosenbaum, P.R., \& Rubin, D.B. (1983). The central role of the propensity score in observational studies for causal effects. Biometrika, 70(1), 41-55.

Sarris, A. (2013). Weather index insurance for agricultural development: Introduction and overview. Agricultural Economics, 44(4-5), 381-384.

Schipmann, C., \& Qaim, M. (2011). Supply chain differentiation, contract agriculture, and farmers' marketing preferences: The case of sweet pepper in Thailand. Food Policy, 36(5), 667-677.

Sherrick, B.J., Barry, P.J., Ellinger, P.N., \& Schnitkey, G.D. (2004). Factors influencing farmers' crop insurance decisions. American Journal of Agricultural Economics, 86(1), 103-114.

Shiferaw, B., Kassie, M., Jaleta, M., \& Yirga, C. (2014). Adoption of improved wheat varieties and impacts on household food security in Ethiopia. Food Policy, 44, 272-284.

Shiferaw, B., Obare, G., \& Muricho, G.S. (2009). Leveraging institutions for collective action to improve markets for smallholder producers in less-favored areas. African Journal of Agricultural and Resource Economics, 3(1), 1-18. 
Shiferaw, B., Tesfaye, K., Kassie, M., Abate, T., Prasanna, B.M., \& Menkir, A. (2014). Managing vulnerability to drought and enhancing livelihood resilience in sub-Saharan Africa: Technological, institutional and policy options. Weather and Climate Extremes, 3, 67-79.

Sina, J., \& Jacobi, P. (2012). Index-based weather insurance: International \& Kenyan experiences. Nairobi: Adaptation to Climate Change and Insurance (ACCI).

Takahashi, K., Ikegami, M., Sheahan, M., \& Barrett, C.B. (2016). Experimental evidence on the drivers of index-based livestock insurance demand in Southern Ethiopia. World Development, 78, 324-340.

Thirtle, C., Lin, L., \& Piesse, J. (2003). The impact of research-led agricultural productivity growth on poverty reduction in Africa, Asia and Latin America. World Development, 31(12), 1959-1975.

Townsend, R.M. (1995). Consumption insurance: An evaluation of risk-bearing systems in low-income economies. Journal of Economic Perspectives, 9(3), 83-102.

Traerup, S.L. (2012). Informal networks and resilience to climate change impacts: A collective approach to index insurance. Global Environmental Change, 22(1), 255-267.

Train, K.E. (2003). Discrete choice methods with simulation. Cambridge: Cambridge University Press.

Vasilaky, K., Osgood, D., Martinez, S., \& Stanimirova, R. (2014). Informal networks within index insurance: Randomizing distance in group insurance. New York: Earth Institute, Columbia University.

Veettil, P.C., Speelman, S., Frija, A., Buysse, J., \& Van Huylenbroeck, G. (2011). Complementarity between water pricing, water rights and local water governance: A Bayesian analysis of choice behaviour of farmers in the Krishna river basin, India. Ecological Economics, 70(10), 1756-1766.

Vermeulen, S.J., Campbell, B.M., \& Ingram, J.S. (2012). Climate change and food systems. Annual Review of Environment and Resources, 37, 195-222.

Wainaina, P., Tongruksawattana, S., \& Qaim, M. (2016). Tradeoffs and complementarities in the adoption of improved seeds, fertilizer, and natural resource management technologies in Kenya. Agricultural Economics, 47(3), 351-362.

Wheeler, T., \& von Braun, J. (2013). Climate change impacts on global food security. Science, 341(6145), 508-513.

Wollni, M., \& Fischer, E. (2015). Member deliveries in collective marketing relationships: evidence from coffee cooperatives in Costa Rica. European Review of Agricultural Economics, 42(2), 287-314.

World Bank. (2008). World development report: Agriculture for development. Washington, DC: The World Bank.

World Bank. (2010). World development report: Development and climate change. Washington, DC: The World Bank.

World Bank. (2011). Weather index insurance for agriculture: Guidance for development practitioners. Washington, DC: The World Bank, Agriculture and rural development discussion paper No. 50. 
Wu, J. (1999). Crop insurance, acreage decisions, and nonpoint-source pollution. American Journal of Agricultural Economics, 81(2), 305-320.

\section{Appendix A: Additional Tables and Figures}

Table A 1: Correlation between instrument and production variables with full sample

\begin{tabular}{lcc}
\hline & \multicolumn{2}{c}{ Instrument (Received training on WII) } \\
\cline { 2 - 3 } Variables & Correlation coefficient & (p-Value) \\
\hline Maize seed (log, '000 Ksh/acre) & 0.051 & $(0.323)$ \\
Fertilizer (log, kg/acre) & 0.032 & $(0.532)$ \\
Pesticide (log, '000 Ksh/acre) & -0.05 & $(0.333)$ \\
Manure (log, MT/acre) & -0.053 & $(0.304)$ \\
Labor (log, mandays/acre) & 0.037 & $(0.471)$ \\
Maize yield (log, kg/acre) & -0.008 & $(0.876)$ \\
Maize revenue (log, '000 Ksh/acre) & 0.024 & $(0.637)$ \\
Total crop revenue (log, '000 Ksh/acre) & -0.031 & $(0.542)$ \\
\hline
\end{tabular}

Table A 2: Correlation between instrument and production variables: Non-insured farmers only

\begin{tabular}{lcc}
\hline & \multicolumn{2}{c}{ Instrument (Received training on WII) } \\
\cline { 2 - 3 } Variables & Correlation coefficient & (p-Value) \\
\hline Maize seed (log, '000 Ksh/acre) & -0.045 & $(0.494)$ \\
Fertilizer (log, kg/acre) & 0.031 & $(0.640)$ \\
Pesticide (log, '000 Ksh/acre) & -0.069 & $(0.296)$ \\
Manure (log, MT/acre) & -0.038 & $(0.562)$ \\
Labor (log, mandays/acre) & -0.026 & $(0.699)$ \\
Maize yield (log, kg/acre) & -0.016 & $(0.811)$ \\
Maize revenue (log, '000 Ksh/acre) & 0.041 & $(0.537)$ \\
Total crop revenue (log, '000 Ksh/acre) & 0.009 & $(0.894)$ \\
\hline
\end{tabular}




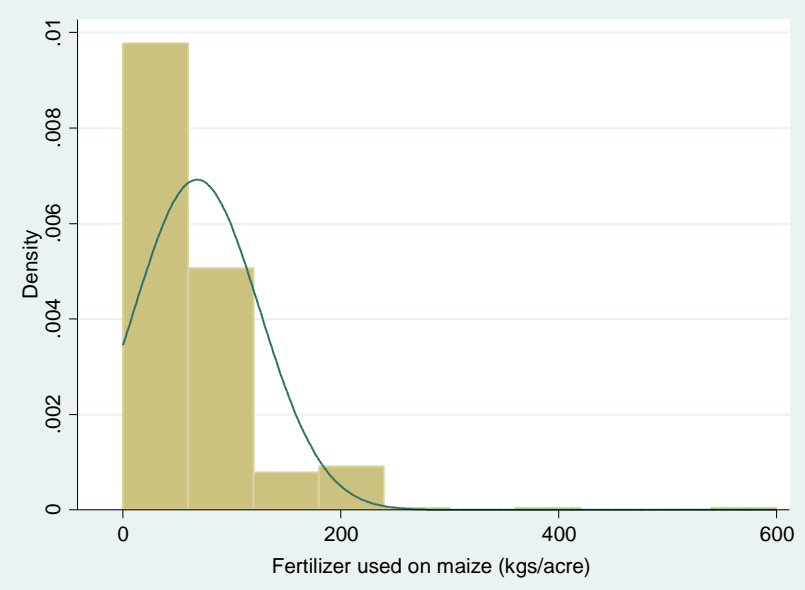

Figure A 1: The distribution for fertilizer

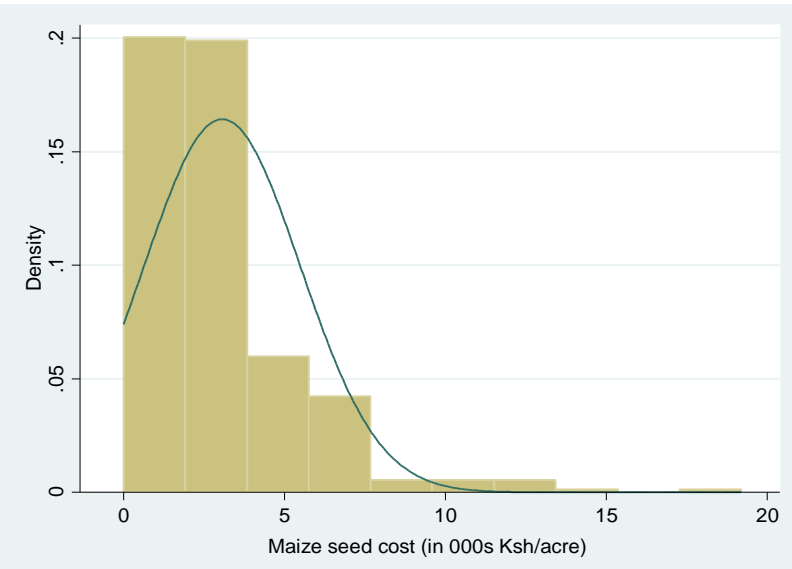

Figure A 3: The distribution for Maize seed expenditure

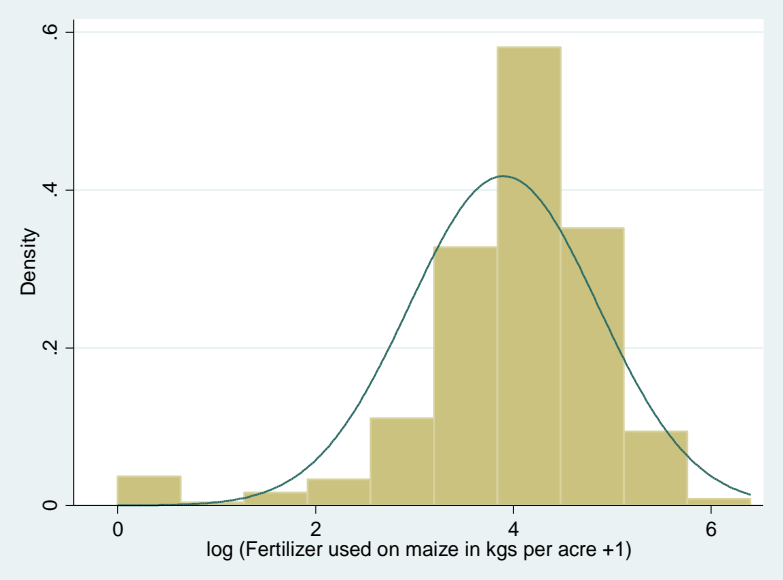

Figure A 2: The distribution for log of fertilizer

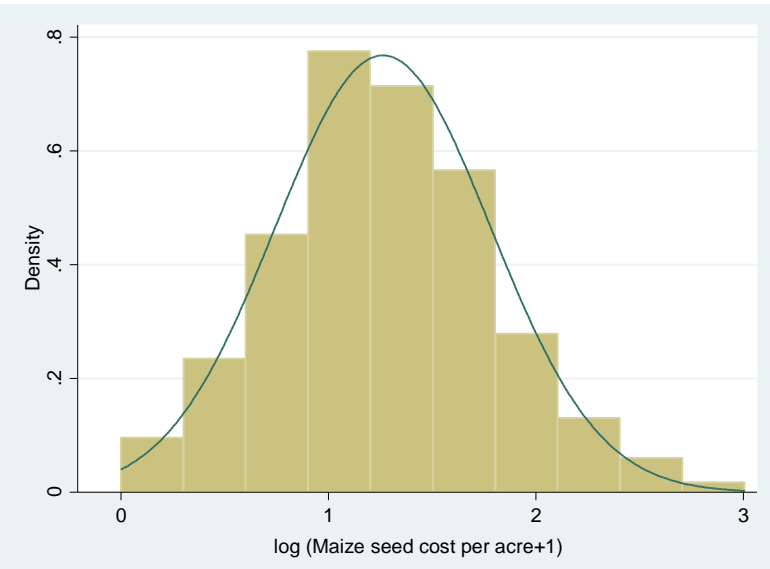

Figure A 4: The distribution for log of Maize seed expenditure 
Table A 3: WII uptake equation (First stage) estimates for maize yield regressions

\begin{tabular}{|c|c|c|c|c|c|c|}
\hline Variables & [1] & [2] & [3] & [4] & [5] & {$[6]$} \\
\hline Seed (log, '000 Ksh/acre) & & & & & & $\begin{array}{c}0.122 \\
(0.121)\end{array}$ \\
\hline Fertilizer (log, kg/acre) & & & & & $\begin{array}{c}0.170 \\
(0.203)\end{array}$ & $\begin{array}{c}0.140 \\
(0.164)\end{array}$ \\
\hline Fertilizer not used (dummy) & & & & & $\begin{array}{l}-0.465 \\
(0.894)\end{array}$ & $\begin{array}{l}-0.514 \\
(0.674)\end{array}$ \\
\hline Pesticide (log, '000 Ksh/acre) & & & & $\begin{array}{c}0.122 \\
(0.112)\end{array}$ & $\begin{array}{c}0.120 \\
(0.101)\end{array}$ & $\begin{array}{c}0.118 \\
(0.097)\end{array}$ \\
\hline Pesticide not used (dummy) & & & & $\begin{array}{l}-0.128 \\
(0.185)\end{array}$ & $\begin{array}{l}-0.018 \\
(0.209)\end{array}$ & $\begin{array}{c}0.002 \\
(0.191)\end{array}$ \\
\hline Manure (log, MT/acre) & & & $\begin{array}{c}0.109 \\
(0.112)\end{array}$ & $\begin{array}{c}0.091 \\
(0.115)\end{array}$ & $\begin{array}{c}0.117 \\
(0.117)\end{array}$ & $\begin{array}{c}0.097 \\
(0.117)\end{array}$ \\
\hline Manure not used (dummy) & & & $\begin{array}{c}0.080 \\
(0.167)\end{array}$ & $\begin{array}{c}0.080 \\
(0.168)\end{array}$ & $\begin{array}{c}0.007 \\
(0.172)\end{array}$ & $\begin{array}{c}0.006 \\
(0.164)\end{array}$ \\
\hline Labor (log, man-days/acre) & & $\begin{array}{c}0.028 \\
(0.130)\end{array}$ & $\begin{array}{c}0.017 \\
(0.131)\end{array}$ & $\begin{array}{c}0.015 \\
(0.131)\end{array}$ & $\begin{array}{l}-0.044 \\
(0.145)\end{array}$ & $\begin{array}{l}-0.073 \\
(0.142)\end{array}$ \\
\hline Maize area (log, acres) & $\begin{array}{c}0.330^{* * * *} \\
(0.119)\end{array}$ & $\begin{array}{c}0.347^{* *} \\
(0.140)\end{array}$ & $\begin{array}{c}0.390 * * * \\
(0.149)\end{array}$ & $\begin{array}{c}0.437 * * * \\
(0.152)\end{array}$ & $\begin{array}{c}0.484^{* * *} \\
(0.148)\end{array}$ & $\begin{array}{c}0.498^{* * *} \\
(0.147)\end{array}$ \\
\hline Male household head (dummy) & $\begin{array}{c}-0.266 \\
(0.185)\end{array}$ & $\begin{array}{l}-0.262 \\
(0.184)\end{array}$ & $\begin{array}{c}-0.255 \\
(0.185)\end{array}$ & $\begin{array}{c}-0.247 \\
(0.187)\end{array}$ & $\begin{array}{l}-0.227 \\
(0.177)\end{array}$ & $\begin{array}{l}-0.219 \\
(0.176)\end{array}$ \\
\hline Education of farmer (years) & $\begin{array}{c}0.019 \\
(0.023)\end{array}$ & $\begin{array}{c}0.019 \\
(0.023)\end{array}$ & $\begin{array}{c}0.017 \\
(0.023)\end{array}$ & $\begin{array}{c}0.013 \\
(0.023)\end{array}$ & $\begin{array}{c}0.013 \\
(0.023)\end{array}$ & $\begin{array}{c}0.011 \\
(0.023)\end{array}$ \\
\hline Age of farmer (years) & $\begin{array}{c}0.020 * * * \\
(0.007)\end{array}$ & $\begin{array}{c}0.020 * * * \\
(0.007)\end{array}$ & $\begin{array}{c}0.020 * * * \\
(0.007)\end{array}$ & $\begin{array}{c}0.020 * * * \\
(0.007)\end{array}$ & $\begin{array}{c}0.022 * * * \\
(0.007)\end{array}$ & $\begin{array}{c}0.021 * * * \\
(0.007)\end{array}$ \\
\hline Off-farm occupation (dummy) & $\begin{array}{c}0.098 \\
(0.197)\end{array}$ & $\begin{array}{c}0.098 \\
(0.197)\end{array}$ & $\begin{array}{c}0.093 \\
(0.196)\end{array}$ & $\begin{array}{c}0.069 \\
(0.194)\end{array}$ & $\begin{array}{c}0.021 \\
(0.182)\end{array}$ & $\begin{array}{c}0.029 \\
(0.182)\end{array}$ \\
\hline Livestock value ('000 Ksh) & $\begin{array}{l}0.0009 \\
(0.001)\end{array}$ & $\begin{array}{l}0.0009 \\
(0.001)\end{array}$ & $\begin{array}{l}0.0008 \\
(0.001)\end{array}$ & $\begin{array}{l}0.0007 \\
(0.001)\end{array}$ & $\begin{array}{l}0.0002 \\
(0.001)\end{array}$ & $\begin{array}{l}0.0001 \\
(0.001)\end{array}$ \\
\hline $\begin{array}{l}\text { Frequency of droughts } \\
\text { (past } 5 \text { years) }\end{array}$ & $\begin{array}{c}0.032 \\
(0.052)\end{array}$ & $\begin{array}{c}0.030 \\
(0.051)\end{array}$ & $\begin{array}{c}0.024 \\
(0.052)\end{array}$ & $\begin{array}{l}0.018 \\
(0.051)\end{array}$ & $\begin{array}{l}-0.007 \\
(0.076)\end{array}$ & $\begin{array}{l}-0.008 \\
(0.059)\end{array}$ \\
\hline $\begin{array}{l}\text { Owns irrigation equipment } \\
\text { (dummy) }\end{array}$ & $\begin{array}{c}0.359 \\
(0.304)\end{array}$ & $\begin{array}{c}0.351 \\
(0.306)\end{array}$ & $\begin{array}{c}0.333 \\
(0.311)\end{array}$ & $\begin{array}{c}0.311 \\
(0.321)\end{array}$ & $\begin{array}{c}0.251 \\
(0.314)\end{array}$ & $\begin{array}{c}0.230 \\
(0.303)\end{array}$ \\
\hline Agricultural extension (contacts) & $\begin{array}{l}-0.052^{*} \\
(0.029)\end{array}$ & $\begin{array}{l}-0.051^{*} \\
(0.029)\end{array}$ & $\begin{array}{l}-0.046^{*} \\
(0.024)\end{array}$ & $\begin{array}{c}-0.048^{* *} \\
(0.024)\end{array}$ & $\begin{array}{l}-0.043 \\
(0.029)\end{array}$ & $\begin{array}{l}-0.042 \\
(0.029)\end{array}$ \\
\hline $\begin{array}{l}\text { Time taken to input market } \\
\text { (log, minutes) }\end{array}$ & $\begin{array}{l}-0.118 \\
(0.102)\end{array}$ & $\begin{array}{l}-0.119 \\
(0.102)\end{array}$ & $\begin{array}{l}-0.110 \\
(0.103)\end{array}$ & $\begin{array}{l}-0.119 \\
(0.104)\end{array}$ & $\begin{array}{l}-0.082 \\
(0.119)\end{array}$ & $\begin{array}{l}-0.072 \\
(0.114)\end{array}$ \\
\hline Received WII training (\%) & $\begin{array}{c}0.769 * * * \\
(0.163)\end{array}$ & $\begin{array}{c}0.763 * * * \\
(0.164)\end{array}$ & $\begin{array}{c}0.785 * * * \\
(0.164)\end{array}$ & $\begin{array}{c}0.787 * * * \\
(0.166)\end{array}$ & $\begin{array}{c}0.582 \\
(0.524)\end{array}$ & $\begin{array}{l}0.557^{*} \\
(0.322)\end{array}$ \\
\hline $\begin{array}{l}\text { Location dummies included } \\
\text { Constant }\end{array}$ & $\begin{array}{c}\text { [Yes] } \\
-1.729 * * * \\
(0.556)\end{array}$ & $\begin{array}{c}\text { [Yes] } \\
-1.732 * * * \\
(0.559)\end{array}$ & $\begin{array}{c}\text { [Yes] } \\
-1.775^{* * *} \\
(0.569)\end{array}$ & $\begin{array}{c}\text { [Yes] } \\
-1.621^{* * *} \\
(0.571)\end{array}$ & $\begin{array}{c}\text { [Yes] } \\
-1.573^{* *} \\
(0.709)\end{array}$ & $\begin{array}{c}\text { [Yes] } \\
-1.554^{* * *} \\
(0.593)\end{array}$ \\
\hline
\end{tabular}


Table A 4: Treatment-effect regression estimates: Intensity of use for animal manure

\begin{tabular}{|c|c|c|c|c|}
\hline \multirow[b]{2}{*}{ Variables } & \multicolumn{2}{|c|}{ All maize farmers } & \multicolumn{2}{|c|}{ Manure users } \\
\hline & $\begin{array}{c}\text { Manure } \\
\text { (log, MT/acre) }\end{array}$ & $\begin{array}{c}\text { WII } \\
\text { uptake }\end{array}$ & $\begin{array}{c}\text { Manure } \\
\text { (log, MT/acre) }\end{array}$ & $\begin{array}{c}\text { WII } \\
\text { uptake }\end{array}$ \\
\hline \multirow[t]{2}{*}{ WII uptake (dummy) } & $-0.656^{*}$ & & $-1.001 * * *$ & \\
\hline & $(0.397)$ & & $(0.353)$ & \\
\hline \multirow[t]{2}{*}{ Age of farmer (years) } & -0.004 & $0.022^{* * *}$ & -0.002 & $0.020 * *$ \\
\hline & $(0.004)$ & $(0.007)$ & $(0.005)$ & $(0.010)$ \\
\hline \multirow[t]{2}{*}{ Age squared } & $-0.0003 *$ & $-0.0006 *$ & -0.0002 & -0.0007 \\
\hline & $(0.0002)$ & $(0.0003)$ & $(0.0003)$ & $(0.0006)$ \\
\hline \multirow{2}{*}{ Education of farmer (years) } & 0.010 & 0.019 & $0.038 *$ & $0.071^{* *}$ \\
\hline & $(0.016)$ & $(0.023)$ & $(0.022)$ & $(0.032)$ \\
\hline \multirow[t]{2}{*}{ Cultivated area (acres) } & $-0.065^{* *}$ & 0.058 & $-0.076^{* *}$ & 0.078 \\
\hline & $(0.029)$ & $(0.039)$ & $(0.037)$ & $(0.050)$ \\
\hline Male labor endowment & 0.017 & 0.005 & 0.121 & 0.194 \\
\hline (adult males/area) & $(0.052)$ & $(0.100)$ & $(0.096)$ & $(0.147)$ \\
\hline Female labor endowment & -0.016 & $-0.266^{* *}$ & -0.034 & $-0.426 * * *$ \\
\hline (adult females/area) & $(0.068)$ & $(0.116)$ & $(0.090)$ & $(0.156)$ \\
\hline \multirow[t]{2}{*}{ Livestock value (log, ‘000 Ksh) } & $0.222 * * *$ & 0.042 & $0.213^{* * *}$ & $0.242 *$ \\
\hline & $(0.039)$ & $(0.070)$ & $(0.069)$ & $(0.131)$ \\
\hline \multirow[t]{2}{*}{ Risk neutral $(5 \leq \mathrm{WTR} \leq 6)^{\mathrm{a}}$} & 0.090 & $-0.662 * *$ & $-0.342 *$ & -0.450 \\
\hline & $(0.169)$ & $(0.257)$ & $(0.204)$ & $(0.343)$ \\
\hline \multirow[t]{2}{*}{ Risk loving $(7 \leq \mathrm{WTR} \leq 10)$} & -0.020 & $-0.396^{*}$ & -0.225 & -0.194 \\
\hline & $(0.138)$ & $(0.217)$ & $(0.172)$ & $(0.290)$ \\
\hline \multirow[t]{2}{*}{ Crop diversification (crop count) } & 0.022 & -0.053 & 0.033 & -0.130 \\
\hline & $(0.051)$ & $(0.095)$ & $(0.070)$ & $(0.120)$ \\
\hline \multirow[t]{2}{*}{ Share of off-farm income (\%) } & -0.171 & -0.430 & 0.201 & -0.489 \\
\hline & $(0.181)$ & $(0.264)$ & $(0.236)$ & $(0.367)$ \\
\hline \multirow[t]{2}{*}{ Access to credit (dummy) } & 0.022 & 0.104 & 0.132 & -0.047 \\
\hline & $(0.115)$ & $(0.169)$ & $(0.144)$ & $(0.234)$ \\
\hline \multirow[t]{2}{*}{ Agricultural extension (contacts) } & 0.006 & $-0.051 * *$ & -0.013 & -0.064 \\
\hline & $(0.023)$ & $(0.023)$ & $(0.020)$ & $(0.053)$ \\
\hline \multirow[t]{2}{*}{ Own transportation means (dummy) } & 0.007 & 0.222 & -0.210 & -0.080 \\
\hline & $(0.127)$ & $(0.190)$ & $(0.153)$ & $(0.266)$ \\
\hline \multirow{2}{*}{$\begin{array}{l}\text { Time taken to input market } \\
\text { (log, minutes) }\end{array}$} & -0.092 & -0.101 & $-0.237 * *$ & -0.196 \\
\hline & $(0.072)$ & $(0.110)$ & $(0.092)$ & $(0.154)$ \\
\hline \multirow[t]{2}{*}{ Fertilizer price (log, Ksh/kg) } & 0.172 & -0.015 & 0.481 & -1.537 \\
\hline & $(0.878)$ & $(0.996)$ & $(0.824)$ & $(1.731)$ \\
\hline Received WII training (dummy) & & $0.797 * * *(0.166)$ & & $0.748 * * *(0.210$ \\
\hline \multirow[t]{2}{*}{ Constant } & 0.022 & -0.200 & -0.052 & 5.595 \\
\hline & (3.737) & $(4.178)$ & (3.493) & (7.186) \\
\hline Location dummies included & [Yes] & [Yes] & [Yes] & [Yes] \\
\hline $\operatorname{ath}(r h o)$ & $0.364(0.226)$ & & $0.711 * * *(0.239)$ & \\
\hline $\ln (\operatorname{sigma})$ & $0.043(0.056)$ & & $-0.066(0.084)$ & \\
\hline Wald test of independent equations & 2.58 & & $8.83^{* * *}$ & \\
\hline Number of observations & 382 & & 214 & \\
\hline
\end{tabular}

Notes: Number of observations is 382 (for farmers growing maize) and 214 (for manure users).

Shown are coefficients with standard errors in parenthesis.

***, **, and * indicate significance at $1 \%, 5 \%$, and $10 \%$ levels, respectively. ${ }^{a}$ Reference is risk averse. 
Appendix B: Survey Questionnaire

UNIVERSITY OF GOETTINGEN

IMPACT OF INSURANCE UPTAKE ON INPUT USE, EX-POST FARMER SATISFACTION AND INFLUENCE OF CONTRACT ATTRIBUTE PREFERENCES ON INSURANCE DEMAND

SECTION 1: GENERAL INFORMATION ABOUT THE INTERVIEW

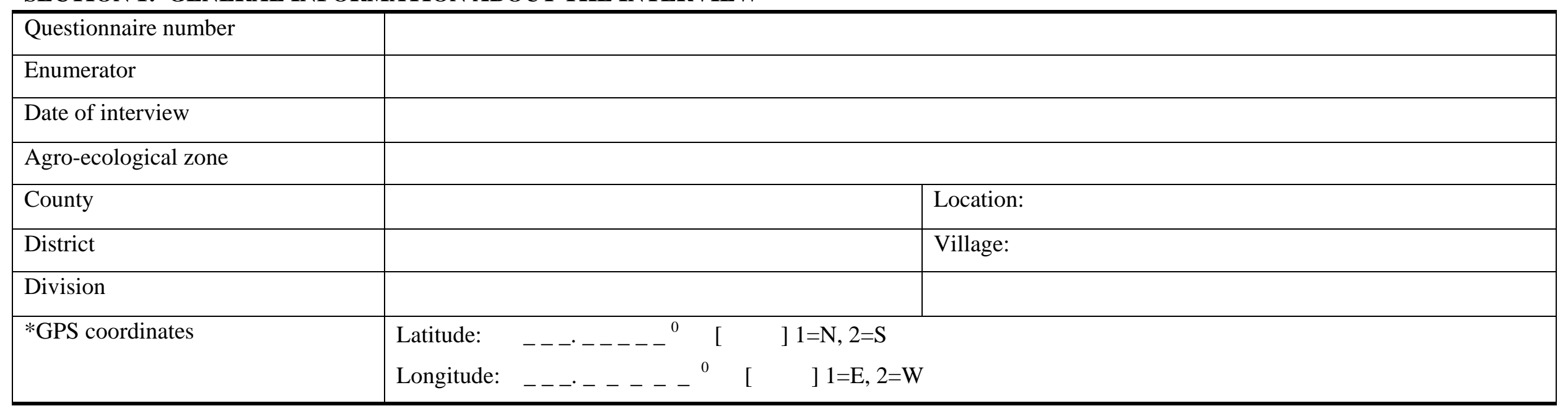

SECTION 2: GENERAL HOUSEHOLD INFORMATION

\begin{tabular}{|c|c|c|c|c|}
\hline Questions & \multicolumn{3}{|l|}{ Codes } & Responses \\
\hline \multicolumn{5}{|l|}{ 2.1.1 Name of respondent } \\
\hline 2.1.2 Are you the household head? & \multicolumn{3}{|l|}{$1=$ Yes; $0=N o$} & {[} \\
\hline \multicolumn{5}{|l|}{ 2.1.3 If No, Name of the household head? } \\
\hline 2.1.4 If No, relationship to the household head? & $\begin{array}{l}\text { 1=Spouse, } \\
\text { 2=Son/Daughter, } \\
\text { 3=Son/Daughter in-law, } \\
\text { 4=Parent }\end{array}$ & $\begin{array}{l}5=\text { Brother } / \text { Sister } \\
6=\text { Brother } / \text { Sister in-law } \\
7=\text { Mother } / \text { father in-law } \\
8=\text { Grandchild } \\
9=\text { Grandparent }\end{array}$ & $\begin{array}{l}\text { 10=Aunt/Uncle } \\
11=\text { Nephew/Niece } \\
\text { 12=Hired worker } \\
13=\text { Others (specify)... }\end{array}$ & \\
\hline
\end{tabular}


2.2. Farmer's and Household Characteristics

\begin{tabular}{|c|c|c|c|c|}
\hline Questions & \multirow{2}{*}{\multicolumn{3}{|c|}{$\begin{array}{l}\text { Codes } \\
0=\text { Female; } 1=\text { Male }\end{array}$}} & Responses \\
\hline 2.2.1 Sex of household head & & & & ] \\
\hline 2.2.2 Age in years (household head) & & & & ] \\
\hline 2.2.3 Marital status (household head) & $\begin{array}{l}\text { 1=Married living with spouse; } \\
\text { 2=Married but spouse away; } \\
\text { 3=Divorced/Separated; } \\
\text { 4=Widow/Widower; }\end{array}$ & & $\begin{array}{l}5=\text { =Single; } \\
6=\text { Others (specify)... }\end{array}$ & ] \\
\hline 2.2.4 Number of years of schooling (household head) & & & & {[} \\
\hline 2.2.5 Number of years of crop farming (household head) & & & & {[} \\
\hline \multirow{6}{*}{$\begin{array}{l}\text { 2.2.6 How many people are currently living in the household? } \\
\text { Including unmarried children away at school/college and hired } \\
\text { employees living there; but excluding short time visitors }\end{array}$} & \multicolumn{3}{|l|}{ Total members } & ] \\
\hline & \multicolumn{3}{|l|}{ i.e. Adults (over 60 years) } & ] \\
\hline & \multicolumn{3}{|l|}{ Adult females (18-59 years) } & {[} \\
\hline & \multicolumn{3}{|l|}{ Adult males (18-59 years) } & ] \\
\hline & \multicolumn{3}{|l|}{ Children (6-17 years) } & ] \\
\hline & \multicolumn{3}{|c|}{ Young children (below 6 years) } & {[} \\
\hline 2.2.7 What is your current occupation? & \multirow{3}{*}{$\begin{array}{l}\text { 1=Farming (Crop + livestock) } \\
\text { 2=Agric. related } \\
\text { salaried employment } \\
\text { 3=Non-Agric. related } \\
\text { salaried employment }\end{array}$} & \multirow{3}{*}{\multicolumn{2}{|c|}{$\begin{array}{l}\text { 4=Self-employed off-farm } \\
5=\text { Casual laborer on-farm } \\
6=\text { Casual laborer off-farm } 7=\text { Others } \\
\text { (specify) }\end{array}$}} & \\
\hline a) Primary occupation & & & & {[} \\
\hline b) Secondary occupation & & & & {[} \\
\hline
\end{tabular}




\section{SECTION 3: EXPOSURE TO SHOCKS AND COPING MECHANISMS}

\section{Introduction:}

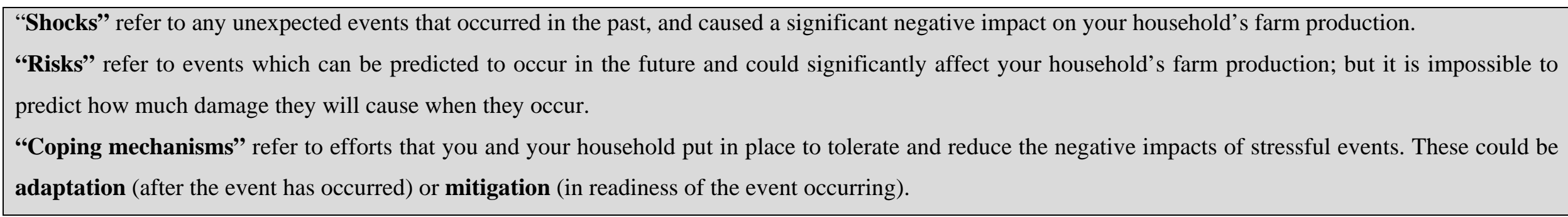

3.1 In this section you will be asked questions about whether your household has ever experienced extreme shocks since 2009 to 2014 ; how often the shocks occurred, and how severely you feel your household was affected by the shock.

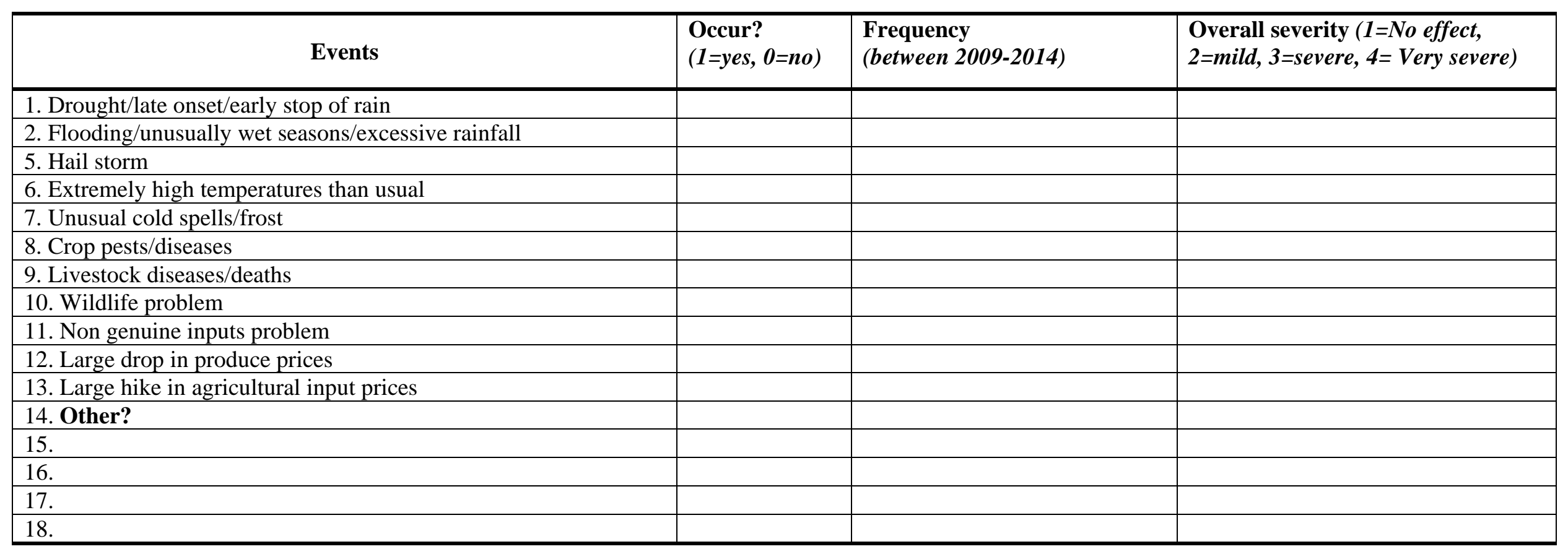


3.2 For each shock you experienced as indicated in the previous question, please provide more information about the adaptation mechanism that your household used when the shock occurred; and how you have mitigated against future risks.

\begin{tabular}{|c|c|c|c|c|c|c|}
\hline $\begin{array}{l}\text { Type of shock } \\
\text { (Reference No. } \\
\text { in table above) }\end{array}$ & $\begin{array}{l}\text { Adaptation } \\
\text { mechanism } \\
\text { (Codes below) }\end{array}$ & $\begin{array}{l}\text { Do you find this } \\
\text { adaptation } \\
\text { mechanism } \\
\text { effective? } \\
\mathbf{1 = y e s , ~} \mathbf{0}=\mathbf{n o}\end{array}$ & $\begin{array}{l}\text { If did nothing to cope } \\
\text { with [...]; give a } \\
\text { reason } \\
\text { (Codes below) }\end{array}$ & $\begin{array}{c}\text { Mitigation } \\
\text { mechanisms } \\
\text { (Codes below) }\end{array}$ & $\begin{array}{l}\text { Do you find this } \\
\text { mitigation } \\
\text { mechanism } \\
\text { effective? } \\
\mathbf{1 = y e s ,} \mathbf{0}=\mathbf{n o}\end{array}$ & $\begin{array}{l}\text { If did nothing to } \\
\text { mitigate against [...]; } \\
\text { give a reason } \\
\text { (Codes below) }\end{array}$ \\
\hline & & & & & & \\
\hline & & & & & & \\
\hline & & & & & & \\
\hline & & & & & & \\
\hline & & & & & & \\
\hline & & & & & & \\
\hline & & & & & & \\
\hline & & & & & & \\
\hline & & & & & & \\
\hline & & & & & & \\
\hline & & & & & & \\
\hline & & & & & & \\
\hline & & & & & & \\
\hline & & & & & & \\
\hline & & & & & & \\
\hline
\end{tabular}




\begin{tabular}{|c|c|c|c|c|c|c|}
\hline $\begin{array}{l}\text { Codes: Adaptation mechanisms } \\
\text { 0 Did nothing } \\
\text { Reduced consumption } \\
\text { 1 Rationed food consumption } \\
2 \text { Spent less money on non-food } \\
\text { items } \\
\text { Disposal of assets } \\
\text { 3 Sold livestock } \\
\text { 4 Sold land } \\
\text { 5 Sold stored harvest } \\
6 \text { Sold household assets } \\
\end{array}$ & \multicolumn{2}{|c|}{$\begin{array}{l}\text { Socio-economic strategies } \\
7 \text { Casual on-farm labor } \\
8 \text { Casual off -farm labor } \\
9 \text { Stopped sending children to } \\
\text { school } \\
10 \text { Sent members to } \\
\text { relatives/friends } \\
11 \text { Relocation }\end{array}$} & \multicolumn{2}{|c|}{$\begin{array}{l}\text { Grant (not paid back) and transfer } \\
12 \text { Help from Government } \\
13 \text { Help from NGOs } \\
14 \text { Help from relatives/neighbors/friends } \\
15 \text { Help from Church based } \\
\text { organizations(CBOs) }\end{array}$} & \multicolumn{2}{|c|}{$\begin{array}{l}\text { Borrowings and savings } \\
16 \text { Borrowed from relatives/ friends/neighbors } \\
17 \text { Borrowed from informal lenders } \\
18 \text { Borrowed from formal financial institutions } \\
19 \text { Used savings in self-help groups e.g. 'merry- } \\
\text { go-round' } \\
20 \text { Used savings in formal financial institutions } \\
21 \text { Requested payment from my debtors } \\
22 \text { Others (specify)... }\end{array}$} \\
\hline \multicolumn{3}{|c|}{$\begin{array}{l}\text { Codes: Reasons for doing nothing to adapt to shocks } \\
1 \text { No idea what to do } \\
2 \text { Expected Government assistance }\end{array}$} & \multicolumn{2}{|c|}{$\begin{array}{l}3 \text { Expected NGOs assistance } \\
4 \text { Expected friends/relatives to help } \\
5 \text { The shock effects were too severe }\end{array}$} & \multicolumn{2}{|c|}{$\begin{array}{l}6 \text { The shock recurs- we've gotten used } \\
7 \text { Others (specify)... }\end{array}$} \\
\hline \multicolumn{2}{|c|}{$\begin{array}{l}\text { Codes: Mitigation Mechanisms } \\
\text { 0=Do nothing } \\
\text { Change farming practice } \\
1 \text { Plant (weather) stress tolerant crops } \\
2 \text { Plant (weather /pest/disease) stress } \\
\text { tolerant varieties } \\
3 \text { Plant early } \\
4 \text { Diversify crops, plot, livestock } \\
5 \text { Increase seed rate } \\
6 \text { Use chemical pesticides } \\
7 \text { Use biological pesticides } \\
8 \text { Crop rotation } \\
9 \text { Soil-water conservation, e.g., reduce } \\
\text { tillage, mulching etc. } \\
10 \text { Reduce chemical fertilizer use }\end{array}$} & \multicolumn{2}{|c|}{$\begin{array}{l}11 \text { Use manure } \\
12 \text { Share cropping } \\
13 \text { Construct terraces } \\
14 \text { Agroforestry } \\
15 \text { Irrigation } \\
16 \text { Rent-in /Borrow-in less affected land } \\
17 \text { Stop farming and rent-out land } \\
\text { Socio-economic strategies } \\
18 \text { Out-migration before the event } \\
19 \text { Preventive health practices (livestock) } \\
20 \text { Members seek additional jobs as farm laborers } \\
21 \text { Members seek additional non-agricultural jobs }\end{array}$} & \multicolumn{2}{|c|}{$\begin{array}{l}\text { Collective action } \\
22 \text { Membership in self-help } \\
\text { groups/SACCOs } \\
23 \text { Collective action building village } \\
\text { infrastructure (e.g. dikes, terraces, } \\
\text { irrigation) } \\
24 \text { Common property resource } \\
\text { management (e.g. forest, lake, } \\
\text { Investment and Savings } \\
25 \text { Investment in security of homestead } \\
\text { and farmland } \\
26 \text { Invest in physical assets } \\
27 \text { Training on how to manage risks } \\
28 \text { Invest in social networks (help } \\
\text { others) }\end{array}$} & $\begin{array}{l}29 \text { Savings in financial } \\
\text { institutions } \\
30 \text { Savings through Table } \\
\text { banking/'Merry-go-round' } \\
31 \text { Buffer stocks (e.g. food, } \\
\text { seeds, fertilizer) } \\
\text { Insurance } \\
32 \text { Buy "Kilimo salama” } \\
33 \text { Buy other agricultural } \\
\text { insurance (specify) } \\
34 \text { Others (specify)... }\end{array}$ \\
\hline \multicolumn{3}{|c|}{$\begin{array}{l}\text { Codes: Reasons for doing nothing to mitigate against future risks } \\
1 \text { No idea what to do } \\
2 \text { Its Government responsibility }\end{array}$} & \multicolumn{2}{|c|}{$\begin{array}{l}3 \text { Household has limited resources } \\
4 \text { Events cannot be certainly predicted }\end{array}$} & \multicolumn{2}{|c|}{$\begin{array}{l}5 \text { The shock recurs- we've gotten used } \\
6 \text { Others (specify)... }\end{array}$} \\
\hline
\end{tabular}


Kindly note that the questions in this section are simply aimed at finding out how crop insurance in Kenya can be improved and not intended to penalize anyone or promote any specific product. Your honest answers will be appreciated.

4.1 Have you ever purchased IBCI products e.g. "Kilimo Salama”? [ ] 0=No, 1=Yes

4.2 If No, why have you never purchased? [ ]1=Limited farming capital; $2=$ No trust in the insurance program;

3=Used alternative risk

management strategies; $4=$ others (specify)...

If No, skip to 4.5

4.3 If yes, which type of IBCI product did you most recently purchase? [ $-\ldots \ldots \ldots-\ldots]$

1=Input insurance, $\quad$ 2=Full investment insurance (inputs \& expected yields), $\quad 3=$ Credit-linked insurance, $\quad$ 4=Contracted grower insurance,

$5=$ Others (specify)...

4.4.1 If yes, in which specific years and seasons since 2009 to-date did you purchase "Kilimo Salama" products?

\begin{tabular}{|c|c|c|c|c|c|}
\hline Year & $\begin{array}{l}\text { Purchased? } \\
(\mathbf{0}=\text { No, }=\text { Yes })\end{array}$ & \multicolumn{2}{|c|}{$\begin{array}{l}\text { Which season? 1=Long rain season (Mar- } \\
\text { Aug), 2=Short rain season (Nov-Feb) }\end{array}$} & \multicolumn{2}{|c|}{$\begin{array}{l}\text { If No in the specific year [...], what hindered you from purchasing? } \\
\text { (Codes below) }\end{array}$} \\
\hline \multicolumn{6}{|l|}{2009} \\
\hline \multicolumn{6}{|l|}{2010} \\
\hline \multicolumn{6}{|l|}{2011} \\
\hline \multicolumn{6}{|l|}{2012} \\
\hline \multicolumn{6}{|l|}{2013} \\
\hline \multicolumn{6}{|l|}{2014} \\
\hline \multicolumn{3}{|c|}{$\begin{array}{l}\text { Codes for hindrance: } \\
1 \text { Limited farming capital } \\
2 \text { Did not farm in that cropping year } \\
3 \text { Did not anticipate risk in that cropping year } \\
4 \text { Insurance was not paying }\end{array}$} & \multicolumn{2}{|c|}{$\begin{array}{l}5 \text { Lost trust in the insurance program } \\
6 \text { Invested in alternative risk management strategies } \\
7 \text { Did not buy Inputs (fertilizers, seeds) i.e. input } \\
\text { insurance was irrelevant }\end{array}$} & 8 Others (specify)... \\
\hline
\end{tabular}


4.4.2 What was the price of the most recent IBCI contract e.g. "Kilimo Salama” that you purchased? Premiums (\% of sum insured),

coverage of acres of cropland

4.4.3 Have you ever received payment from your IBCI insurance provider? $\quad[\quad]$ 0=No, 1=Yes

4.4.4 If yes, in which year was this payment received?

4.4.5 If yes, did you understand how this indemnity payment was arrived at? [

] $0=$ No, $1=$ Yes (explain)

4.4.6 Have there been years when you purchased one of the IBCI products but the insurance provider failed to pay, yet you experienced severe yield loss on your farm? [

] $0=$ No, $1=$ Yes

4.4.7 If Yes (4.4.6), please provide details about the specific years and the reason why you experienced yield loss on your farm:

\begin{tabular}{|c|c|c|c|c|}
\hline \multicolumn{2}{|c|}{ Year with yield loss but not paid } & \multicolumn{3}{|c|}{ If yes in column 2, reason for yield loss on your farm } \\
\hline 1 & 2 & (3) Reason & & des \\
\hline 2009 & ] $0=$ No, $1=$ Yes & & \multirow{6}{*}{$\begin{array}{l}1=\text { Pest/disease infection } \\
2=\text { Hailstorm } \\
3=\text { Frost } \\
4=\text { Theft } \\
5=\text { Sickness of family member } \\
6=\text { Applied inadequate inputs }\end{array}$} & \multirow[t]{6}{*}{ 7=Others (specify)... } \\
\hline 2010 & ] $0=$ No, $1=$ Yes & & & \\
\hline 2011 & ] $0=$ No, $1=$ Yes & & & \\
\hline 2012 & ] $0=$ No, $1=$ Yes & & & \\
\hline 2013 & ] $0=$ No, $1=$ Yes & & & \\
\hline 2014 & ] $0=$ No, $1=$ Yes & & & \\
\hline
\end{tabular}

4.4.8 Have you ever received payment from the insurance provider when your crop yields were averagely normal? [

] $0=$ No, $1=$ Yes

4.4.9 If yes (4.4.8), in which years

] $0=$ No, $1=$ Yes

] (Use a scale of 1-5: 1=very near, 2=near, 3=average, 4=far and $5=$ very far)

4.7 Would you say that the information collected at the (nearest) weather station perfectly represents the situation on your own farm?

[ ] 0=No, 1=Yes 
4.8 Insurance is sometimes sold through local agro-dealers. Which is the most convenient public means of transport from your homestead to the nearest local agro-dealer? [ ] 1 1=by foot, 2=by motorcycle, 3=by bus ("Matatu”), 4=others (specify)

4.9 What is the time-taken to get there? [_-

4.10 How much would it cost you going by that most convenient public transport means? In KES

4.11 Do you know any one among your relatives, friends and neighbors etc. who started buying IBCI e.g. "Kilimo Salama” insurance before you?

\section{[ ] $0=$ No, $1=$ Yes}

4.12 If yes, where does this person(s) live? [

] $1=$ within the village, $2=$ in the neighboring village, $3=$ in a far-away village?

4.13 What is your exact relationship with this person? [ ] ] 1=relative; 2=friend; 3=neighbor; 4=others (specify)

4.14 Apart from "Kilimo Salama”, have you ever purchased any form of general insurance before? [ ] ] 0=No, 1=Yes

4.15 If yes, which form of general insurance did you purchase? [

] 1= Indemnity-based crop insurance; $2=$ Indemnity-based loan insurance; $3=$ Indemnity-based livestock insurance; $5=$ health insurance; $6=$ motor vehicle insurance; $7=$ =others (specify)

\subsection{Access to information and extension services in the previous year (Jan-Dec 2013)}

\begin{tabular}{|c|c|c|c|c|c|}
\hline \multirow{2}{*}{\multicolumn{2}{|c|}{ Did you receive information or training on [...] during 2013 ? }} & \multicolumn{4}{|c|}{$\begin{array}{l}\text { If Yes in column 2, two main sources of information on [...] } \\
\text { and number of interactions with source during the year } 2013\end{array}$} \\
\hline & & \multirow{2}{*}{$\begin{array}{c}\begin{array}{c}\text { Source } 1 \\
\text { (codes below) }\end{array} \\
3\end{array}$} & \multirow{2}{*}{$\begin{array}{c}\begin{array}{c}\text { Number of } \\
\text { contacts }\end{array} \\
4\end{array}$} & \multirow{2}{*}{$\begin{array}{c}\begin{array}{c}\text { Source } 2 \\
\text { (codes below) }\end{array} \\
5\end{array}$} & \multirow{2}{*}{$\begin{array}{c}\text { Number of contacts } \\
\mathbf{6}\end{array}$} \\
\hline 1 & $\begin{array}{c}2 \\
0=\text { No, } 1=\text { Yes }\end{array}$ & & & & \\
\hline 1) Crop insurance e.g. “Kilimo Salama” & {$[\quad]$} & & & & \\
\hline $\begin{array}{l}\text { 2) General financial literacy i.e. bank services, } \\
\text { formal money markets etc. }\end{array}$ & {$[\quad]$} & & & & \\
\hline 3) New seed varieties & ] & & & & \\
\hline 4) Field pest \& disease control & ] & & & & \\
\hline 5) Soil fertility \& fertilizer application & ] & & & & \\
\hline 6) Irrigation & {$[\quad]$} & & & & \\
\hline $\begin{array}{l}\text { 7) Conservation agriculture \& soil water } \\
\text { management e.g. mulching, minimum tillage, crop } \\
\text { rotation etc. }\end{array}$ & {$\left[\begin{array}{ll}{[} & ]\end{array}\right.$} & & & & \\
\hline 8) Adaptation to climate change $\&$ reducing $\mathrm{CO}^{2}$ & ] & & & & \\
\hline
\end{tabular}




\begin{tabular}{|c|c|c|c|}
\hline emissions in agriculture & & & \\
\hline 9) Agro-forestry/ tree planting & [ ] $]$ & & \\
\hline 10) Improved produce storage methods & ] & & \\
\hline 11) Processing \& value addition & {[} & & \\
\hline 12) Collective action/ farmer organization & [ ] $]$ & & \\
\hline 13) Others (specify)... & [ ] $]$ & & \\
\hline $\begin{array}{l}\text { Codes: Source of information or training organizer } \\
\text { 1= Ministry of Agriculture extension officers, } \\
2=\text { Syngenta foundation extension officers, } \\
3=\text { Kilimo Salama helpline service } \\
4=\text { Other input Co. extension officers (specify Co.)... } \\
5=\text { Officers from NGOs/community developmen } \\
\text { (Specify name)... }\end{array}$ & tt organizations & $\begin{array}{l}6=\text { Meetings of the local administration (chief) } \\
7=\text { Church officials, } \\
8=\text { Family member (specify) } \ldots \\
9=\text { Fellow farmers in informal network, } \\
10=\text { Fellow members of a group/association, } \\
11=\text { Local agro-dealers, } \\
12=\text { Advertisement/programme on Radio, }\end{array}$ & $\begin{array}{l}\text { 13= Print media, } \\
\text { 14= Advertisement/programme on } \\
\text { the Television, } \\
\text { 15= Internet, } \\
\text { 16= Others (specify... }\end{array}$ \\
\hline
\end{tabular}

\section{SECTION 5: SATISFACTION AND LOYALTY TOWARDS EXISTING WEATHER BASED INSURANCE}

5.1 Based on your knowledge or actual insurance experience, what is your level of satisfaction with the existing IBCI program in Kenya?

[ ] 1 = Very dissatisfied, 2=Dissatisfied, 3=Undecided/neutral, $\mathbf{4}=$ =Satisfied, 5=Very satisfied

5.2 Please indicate your level of agreement towards the following statements about IBCI programs e.g. "Kilimo Salama”. (Tick appropriately based on a scale of 1 to 5: 1 = completely false, $2=$ false, $3=$ undecided/neutral, $4=$ true, $5=$ completely true)

\begin{tabular}{|c|c|c|c|c|c|c|}
\hline & Statement & $\begin{array}{c}\text { Completely } \\
\text { false }\end{array}$ & False & $\begin{array}{c}\text { Undecided/ } \\
\text { Neutral }\end{array}$ & True & $\begin{array}{c}\text { Completely } \\
\text { true }\end{array}$ \\
\hline & Farmer expectations & & & & & \\
\hline 1 & It is a form of support for needy farmers & & & & & \\
\hline 2 & It is meant to cover farmers against production risks & & & & & \\
\hline 3 & It makes farmers relaxed and more confident in their farming & & & & & \\
\hline
\end{tabular}


Perceived Quality

$4 \quad$ It guarantees farmers a payment every time there is shortage or excess rainfall

5 Its purchase process is very convenient for farmers

6 The payment process is very fast and convenient for farmers

7 Compared to other crop insurance programs, it performs better

\section{Intimacy}

8 The insurance provider communicates directly with their clients

9 The local agents selling this kind of insurance are polite and friendly

10 The experts/officers training farmers are knowledgeable and helpful Trust

11 Its purchase system is reliable and rarely fails

12 Its payment system is reliable and rarely fails

13 Overall I trust the weather stations and the process that determines when payments should be made

\section{Perceived Value}

14 This kind of insurance comes at an affordable cost to farmers

15 Considering the relaxed feeling insured farmers receive, I think this kind of insurance is valuable

16 Considering the cost and the payment after rainfall failure, I think this kind of insurance is valuable

\section{Complaints}

17 If farmers have any complain they can easily present it to the insurance provider

18 The insurance provider is polite in listening to complains

19 The insurance provider seriously follows up on complaints

\section{Loyalty}

20 I always say good things about it to fellow farmers and friends

21 I always encourage my fellow farmers to buy it

\begin{tabular}{|l|l|}
\hline 22 & I think next year I will buy crop insurance again \\
\hline
\end{tabular} 


\section{SECTION 6: CONTRACT ATTRIBUTE PREFERENCES AND CHOICE EXPERIMENT}

\section{Interviewer:}

Ask the respondent to look keenly at the choice cards representing insurance contracts, explain to him/her what the attributes mean based on Attachment 2 , and then ask him/her to indicate which one they would prefer to buy. Then record the profile number of the insurance contract chosen in that choice set. Each respondent will be given random sets of three choice cards four times. Inform them further that if they don't find any of the alternatives appealing to them, they are allowed to reject all of them. The respondents are also free to ask for further explanations or to take a short break in between to allow them to concentrate.

6.1 Interviewer: From the choice cards provided together with this questionnaire, present random choice set number [

] to the respondent Assuming

that the cards in this first choice set were the only insurance contracts being marketed, which insurance contract would you buy?

\begin{tabular}{|c|c|}
\hline Preferred weather index insurance contract & None of the contracts \\
\hline Profile card No. [ & Tick [ ] ] \\
\hline
\end{tabular}

\subsection{Interviewer: Present random choice set number [ ] to the respondent}

Assuming that the cards in this second choice set were the only insurance contracts being marketed, which insurance contract would you buy?

\begin{tabular}{|c|c|}
\hline Preferred weather index insurance contract & None of the contracts \\
\hline Profile card No. [ & Tick [ ] $]$ \\
\hline
\end{tabular}

6.3 Interviewer: Present random choice set number [

] to the respondent

Assuming that the cards in this third choice set were the only insurance contracts being marketed, which insurance contract would you buy?

\begin{tabular}{|c|c|}
\hline Preferred weather index insurance contract & None of the contracts \\
\hline Profile card No. [ & Tick [ ] ] \\
\hline
\end{tabular}

\subsection{Interviewer: Present random choice set number [ ] ] to the respondent}

Assuming that the cards in this fourth choice set were the only insurance contracts being marketed, which insurance contract would you buy?

\begin{tabular}{|c|c|}
\hline Preferred weather index insurance contract & None of the contracts \\
\hline Profile card No. [ & Tick [ ] ] \\
\hline
\end{tabular}


SECTION 7: SOCIAL CAPITAL AND NETWORKING

7.1 Does any member of your household belong to any group? [ ] $\mathbf{0}=\mathbf{N o}, \mathbf{1}=$ Yes

7.2 If yes, please provide details of his/her membership:

\begin{tabular}{|c|c|c|c|}
\hline $\begin{array}{l}\text { Household member } \\
\text { (Codes below) }\end{array}$ & $\begin{array}{l}\text { Type of group based on the main } \\
\text { function of the group (Codes below) }\end{array}$ & No of years in the group & $\begin{array}{c}\text { Member's current role in group } \\
\text { (1=Official; } \mathbf{2}=\mathbf{E x - o f f i c i a l ;} \mathbf{3}=\text { Ordinary } \\
\text { member) }\end{array}$ \\
\hline & & & \\
\hline & & & \\
\hline & & & \\
\hline & & & \\
\hline & & & \\
\hline $\begin{array}{l}\text { Codes: HH member: } \\
\text { 1=Household head } \\
\text { 2=Spouse } \\
\text { 3=Son/Daughter } \\
\text { 4=Grand child } \\
\text { 5=Parent } \\
\text { 6=Brother/Sister }\end{array}$ & $\begin{array}{l}\mathbf{7}=\text { Hired worker } \\
\mathbf{8}=\text { Others (specify)... }\end{array}$ & $\begin{array}{l}\text { Codes: Type of group: } \\
\text { 1= Local farmers association; } \\
\text { 2=Traders' association; } \\
\text { 3=Women’s association; } \\
\text { 4=Youth association; } \\
\text { 5=Professional welfare } \\
\text { association; }\end{array}$ & 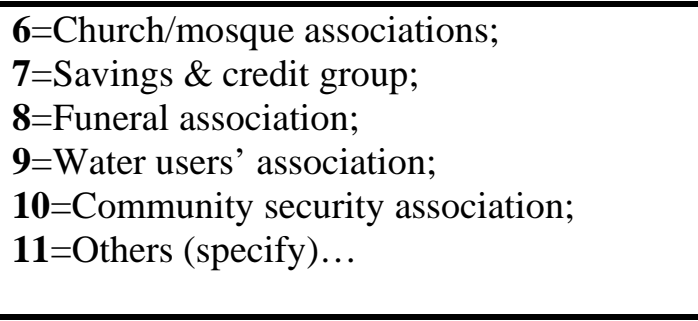 \\
\hline
\end{tabular}




\section{SECTION 8: LAND OWNERSHIP, TENURE AND ASSET ENDOWMENT}

8.1 How much land in total does your household own? _._._._._. _ _ Acres

8.2 What is the value of an acre of land in your area? KES

8.3 Do you have title for the land your household owns? [ ] $\mathbf{0}=$ No, $\mathbf{1}=$ Yes

8.4 Please provide details about your land holding during the previous year (Jan-Dec 2013)

\begin{tabular}{|l|l|l|l|l|l|l|}
\hline & \multicolumn{5}{|c|}{ Tenure system (in acres) } \\
\cline { 2 - 7 } & $\begin{array}{c}\text { Own land used } \\
\text { for farming }\end{array}$ & Rented in land & Rented out land & Borrowed in land & Borrowed out land & Communal land used \\
\hline Mar-April rain season (2013) & & & & & & \\
\hline Oct-Nov rain season (2013) & & & & & \\
\hline
\end{tabular}

8.5 What is your general perception about the fertility of the farm land used in the past 12 months? [ ] $1=$ =not fertile, $2=$ =moderately fertile, $3=$ fertile

8.6 Household asset endowment in the previous year (Jan-Dec 2013). Assets acquired in 2014 should be excluded

\begin{tabular}{|l|l|l|l|l|}
\hline \multicolumn{2}{|c|}{ Do you own this asset? } & 1=Yes, $0=$ No & Total Number & $\begin{array}{l}\text { How much on average would you sell a unit of } \\
\text { asset }[\ldots] \text { in its current state (in KES)? }\end{array}$ \\
\hline 1 & Tractor & & & \\
\hline 2 & Ox-plough & & & \\
\hline 3 & Irrigation equipment & & & \\
\hline 4 & Hoe/Jembe & & & \\
\hline 5 & Sickle & & & \\
\hline 6 & Spade or shovel & & & \\
\hline 7 & Axe & & & \\
\hline 8 & Machete/ Panga & & & \\
\hline 9 & Slasher & & & \\
\hline 10 & Mattock & & & \\
\hline 11 & Donkey/ox / push cart & & & \\
\hline 12 & Wheelbarrow & & & \\
\hline 13 & Bicycle & & & \\
\hline 14 & Motorcycle & & & \\
\hline
\end{tabular}




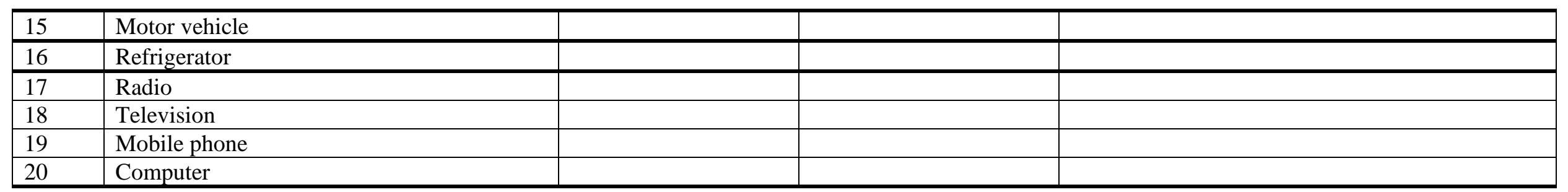

\section{SECTION 9: GENERAL FARMING INFORMATION}

9.1 Please provide the following details for the major crops grown by the farmer in the previous year (Jan-Dec 2013)?

\begin{tabular}{|c|c|c|c|c|c|c|c|c|}
\hline \multirow[b]{2}{*}{ No. } & \multirow[b]{2}{*}{ Crop } & \multicolumn{2}{|c|}{ Size (acres) } & \multicolumn{2}{|c|}{$\begin{array}{c}\text { Output (Bags, kg, etc. for } \\
\text { each season) }^{\mathrm{a}}\end{array}$} & \multicolumn{3}{|c|}{ Revenue } \\
\hline & & Long rains season & Short rains season & Long rains & Short rains & $\begin{array}{l}\text { Quantity } \\
\text { consumed } \\
\text { (Bags, kgs } \\
\text { etc. yearly) }\end{array}$ & $\begin{array}{l}\text { Quantity } \\
\text { sold } \\
\text { (Bags, kgs } \\
\text { etc. yearly) }\end{array}$ & $\begin{array}{l}\text { Average } \\
\text { Price/unit }\end{array}$ \\
\hline 1 & & & & & & & & \\
\hline 2 & & & & & & & & \\
\hline 3 & & & & & & & & \\
\hline 4 & & & & & & & & \\
\hline 5 & & & & & & & & \\
\hline 6 & & & & & & & & \\
\hline 7 & & & & & & & & \\
\hline 8 & & & & & & & & \\
\hline
\end{tabular}

Specify the quantity and unit of measurement for the crop output 
9.2 For each crop mentioned above please give details of the cost of production in the previous year (Jan-Dec 2013). Details should be the summations for all plots and the two crop seasons mentioned above. In case of intercrops only record the cost once to avoid double counting.

\begin{tabular}{|c|c|c|c|c|c|c|c|c|c|c|c|}
\hline \multirow{2}{*}{$\begin{array}{c}\text { Crop } \\
\text { (Reference. No. } \\
\text { in table above) }\end{array}$} & \multirow[b]{2}{*}{$\begin{array}{c}\text { Land rent }^{\mathbf{a}} \\
\text { (Ksh per acre) }\end{array}$} & \multicolumn{3}{|c|}{ Seeds } & \multicolumn{2}{|c|}{ Fertilizer } & \multicolumn{2}{|c|}{ Manure } & \multicolumn{2}{|c|}{ Pesticide } & \multirow[b]{2}{*}{$\begin{array}{c}\text { Machinery } \\
{\text { (Cost })^{\mathrm{b}}}\end{array}$} \\
\hline & & $\begin{array}{c}\text { Variety type } \\
(0=\text { local, } \\
1=\text { certified })\end{array}$ & Quantity & $\begin{array}{l}\text { Cost } \\
\text { (Ksh) }\end{array}$ & Quantity & Cost (Ksh) & Quantity & Cost (Ksh) & Quantity & $\begin{array}{l}\text { Cost } \\
\text { (Ksh) }\end{array}$ & \\
\hline & & & & & & & & & & & \\
\hline & & & & & & & & & & & \\
\hline & & & & & & & & & & & \\
\hline & & & & & & & & & & & \\
\hline & & & & & & & & & & & \\
\hline & & & & & & & & & & & \\
\hline & & & & & & & & & & & \\
\hline & & & & & & & & & & & \\
\hline
\end{tabular}

${ }^{\mathrm{a}}$ Total land rent for the whole year for each of the crop on rented land

${ }^{\mathrm{b}}$ If the farmer owns machinery ask for local rates of machinery use 
9.3 For each crop listed above please provide the following details on labor use and cost for the previous year (Jan-Dec 2013)?

\begin{tabular}{|c|c|c|c|c|c|c|c|c|c|c|c|c|c|}
\hline \multirow{2}{*}{$\begin{array}{c}\text { Crop } \\
\text { (Reference. } \\
\text { No. in table } \\
\text { above) }\end{array}$} & \multicolumn{3}{|c|}{ Ploughing } & \multicolumn{3}{|c|}{ Planting } & \multicolumn{3}{|c|}{ Field practices } & \multicolumn{3}{|c|}{ Harvesting } & \multirow[b]{2}{*}{$\begin{array}{c}\text { Cost } \\
\text { (Ksh/person/day) }\end{array}$} \\
\hline & $\begin{array}{l}\text { Labor type } \\
(0=\text { family, } \\
1=\text { hired })\end{array}$ & Persons & $\begin{array}{l}\text { Days } \\
\text { worked }\end{array}$ & $\begin{array}{l}\text { Labor type } \\
(0=\text { family, } \\
1=\text { hired })\end{array}$ & Persons & $\begin{array}{l}\text { Days } \\
\text { worked }\end{array}$ & $\begin{array}{l}\text { Labor type } \\
(0=\text { family, } \\
1=\text { hired })\end{array}$ & Persons & $\begin{array}{l}\text { Days } \\
\text { worked }\end{array}$ & $\begin{array}{l}\text { Labor type } \\
(0=\text { family, } \\
1=\text { hired })\end{array}$ & Persons & $\begin{array}{l}\text { Days } \\
\text { worked }\end{array}$ & \\
\hline & & & & & & & & & & & & & \\
\hline & & & & & & & & & & & & & \\
\hline & & & & & & & & & & & & & \\
\hline & & & & & & & & & & & & & \\
\hline & & & & & & & & & & & & & \\
\hline & & & & & & & & & & & & & \\
\hline & & & & & & & & & & & & & \\
\hline & & & & & & & & & & & & & \\
\hline & & & & & & & & & & & & & \\
\hline
\end{tabular}

9.5 Please list all categories and numbers of livestock owned in the previous year (Jan-Dec 2013).

\begin{tabular}{|c|c|c|c|c|c|}
\hline & Animal/Birds & Number & & Animal/Birds & Number \\
\hline 1 & Cattle & & 7 & & \\
\hline 2 & Goats & & 8 & & \\
\hline 3 & Sheep & & 9 & & \\
\hline 4 & Chicken & & 10 & & \\
\hline 5 & Donkeys & & 11 & & \\
\hline 6 & Pigs & & 12 & & \\
\hline
\end{tabular}


9.6 For each livestock category please provide details of revenue and cost of livestock production in the previous year (Jan-Dec 2013).

\begin{tabular}{|c|c|c|c|c|c|c|c|}
\hline \multirow{2}{*}{ Animal/Birds } & \multicolumn{3}{|c|}{ Total Revenue (Jan-Dec 2013) } & \multicolumn{4}{|c|}{ Total Cost of Production for Jan-Dec 2013 (Ksh) } \\
\hline & Units consumed & Units sold & Price per unit & Fodder & Labor & Veterinary care & Other \\
\hline \multicolumn{8}{|l|}{ Cattle } \\
\hline \multicolumn{8}{|l|}{ Goats } \\
\hline \multicolumn{8}{|l|}{ Sheep } \\
\hline \multicolumn{8}{|l|}{ Chicken } \\
\hline \multicolumn{8}{|l|}{ Donkeys } \\
\hline \multicolumn{8}{|l|}{ Pigs } \\
\hline & & & & & & & \\
\hline & & & & & & & \\
\hline & & & & & & & \\
\hline & & & & & & & \\
\hline & & & & & & & \\
\hline \multicolumn{8}{|l|}{ Animal product } \\
\hline \multicolumn{8}{|l|}{ Milk } \\
\hline \multicolumn{8}{|l|}{ Eggs } \\
\hline & & & & & & N & \\
\hline & & & & & & & \\
\hline & & & & & & N & \\
\hline & & & & & & N & \\
\hline & & & & & & & \\
\hline & & & & & & & \\
\hline & & & & & & & \\
\hline & & & & & & & \\
\hline
\end{tabular}


SECTION 10: HOUSEHOLD OFF-FARM INCOME, ACCESS TO CREDIT AND USE OF MOBILE PHONE MONEY TRANSFER

10.1 Please tell me about other sources of income for your household in the previous year (Jan-Dec 2013)

\begin{tabular}{|c|c|c|c|c|c|c|}
\hline \multicolumn{3}{|c|}{ Did you or any household member earn income from [...] in $2013 ?$} & \multirow[t]{2}{*}{$1=$ yes, $0=$ No } & \multirow[t]{2}{*}{$\begin{array}{l}\text { Number of } \\
\text { times/frequency }\end{array}$} & \multirow{2}{*}{$\begin{array}{c}\text { Average income } \\
\text { per unit (in } \\
\text { KES) } \\
\end{array}$} & \multirow{2}{*}{$\begin{array}{c}\text { Total income } \\
\text { earned (in } \\
\text { KES) } \\
\end{array}$} \\
\hline \multirow{4}{*}{ Labor } & 1 & Casual agricultural labor & & & & \\
\hline & 2 & Casual non-agricultural labor & & & & \\
\hline & 3 & Salary & & & & \\
\hline & 4 & Pension & & & & \\
\hline \multirow{4}{*}{ Remittances } & 5 & Food aid & & & & \\
\hline & 6 & Income, gifts from relatives & & & & \\
\hline & 7 & $\begin{array}{l}\text { Income, gifts from government or NGO } \\
\text { programs }\end{array}$ & & & & \\
\hline & 8 & Indemnity payments from insurer & & & & \\
\hline Rent & 10 & Rent received (land or house) & & & & \\
\hline Self-employed hand works & 11 & (specify) & & & & \\
\hline Small businesses & 12 & (specify) & & & & \\
\hline Forest products trade & 13 & (specify) & & & & \\
\hline Others specify & 14 & & & & & \\
\hline
\end{tabular}

10.2 Household credit needs and sources during the previous year (Jan-Dec 2013)

\begin{tabular}{|c|c|c|c|c|c|}
\hline \multirow{2}{*}{\multicolumn{2}{|c|}{ Did you need credit for the following reasons...? }} & \multirow{2}{*}{$\begin{array}{l}\text { If yes, in column } 2 \text {, } \\
\text { then did you get it? } \\
\text { 0=No } 1=\text { Yes }\end{array}$} & \multicolumn{3}{|c|}{ If Yes in column 3} \\
\hline & & & Source of credit & How much did & Did you get the amount \\
\hline Farming needs & $0=$ No,1 $=$ Yes & & & & \\
\hline 1)Buying seeds/ fertilizer/chemicals & [ ] ] & & & & \\
\hline 2) Buying farm equipment \& machinery & ] & & & & \\
\hline 3) Ploughing expenses & ] & & & & \\
\hline 4) Others (specify)... & ] & & & & \\
\hline Non-farming needs (specify)... & ] & & & & \\
\hline
\end{tabular}




\subsection{Use of mobile phone money transfer}

10.3.1 Does any member of your household own a mobile phone?

[ ] $0=$ No, $1=$ Yes

10.3.2 If yes, is s/he a registered mobile money transfer subscriber?

[ ] $0=$ No, $1=$ Yes

10.3.3 If yes (10.3.2), to which mobile money transfer service is s/he subscribed? [

1=M-PESA, 2=Airtel money, 3=Yu-cash, 4=Orange money, $5=$ =thers (specify)...

10.3.4 If yes (10.3.2) how frequently did s/he use mobile money transfer services in the previous year (Jan-Dec 2013)? [

] 1= rarely, $2=$ frequently,

$3=$ very frequently

\section{SECTION 11: RISK ATTITUDES}

11. How do you view yourself; are you a person who is generally willing to take risks or do you more often avoid taking risks? Please rate yourself based on a scale of 1-10:

Interviewer: Circle appropriately

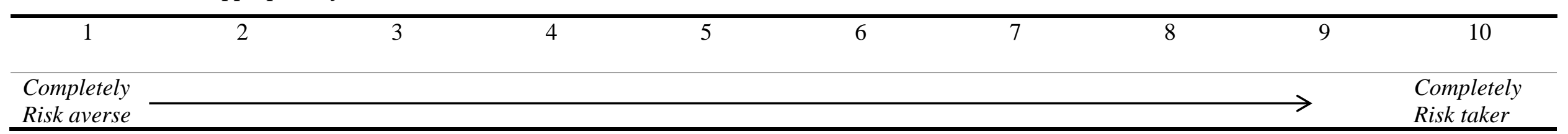

THANK YOU VERY MUCH FOR YOUR TIME 